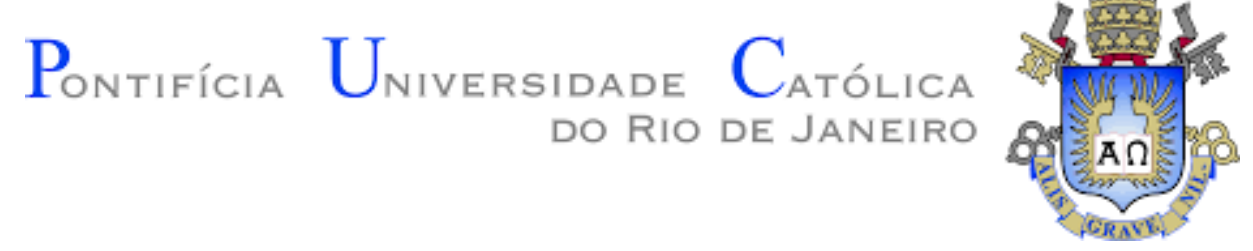

Antonio Carlos de Gois Sales

\title{
USO E COBERTURA DO SOLO - DO QUILOMBO ÀS AGROVILAS: AS PAISAGENS E TERRITÓRIOS VAZANTEIROS NA REGIÃO MÉDIO SÃO FRANCISCO, BOM JESUS DA LAPA (BA)
}

Dissertação de Mestrado

Dissertação apresentada como requisito parcial para obtenção do grau de Mestre em Geografia pelo programa de Pós-graduação em Geografia, do Departamento de Geografia e Meio Ambiente da PUC-Rio.

Orientador: Rodrigo Penna Firme Pedrosa 
Antonio Carlos de Gois Sales

\section{USO E COBERTURA DO SOLO - DO QUILOMBO ÀS AGROVILAS: AS PAISAGENS E TERRITÓRIOS VAZANTEIROS NA REGIÃO MÉDIO SÃO FRANCISCO, BOM JESUS DA LAPA (BA)}

Dissertação apresentada como requisito parcial para obtenção do grau de Mestre pelo Programa de PósGraduação em Geografia da PUC-Rio.

Aprovada pela Comissão Examinadora abaixo:

Prof. Dr. Rodrigo Penna Firme Pedrosa

Orientador

Departamento de Geografia - PUC-Rio

Profa. Dra. Laila Thomaz Sandroni

USP

Prof. Dr. Wilson Messias dos Santos Junior

SEEDUC - RJ 
Todos os direitos reservados. É proibida a reprodução total ou parcial do trabalho sem autorização da universidade, da autora e do orientador.

\section{Antonio Carlos de Gois Sales}

Graduou-se em Geografia na UERJ (Universidade do Estado do Rio de Janeiro) em 2012 . Trabalhou na implementação de diversos Sistemas de Informação Geográficas em instituições publicas e privadas. Constituiu carreira na consultoria ambiental voltada para o licenciamento de empreendimentos

Ficha Catalográfica

Sales, Antonio Carlos de Gois

Uso e cobertura do solo - do quilombo às agrovilas : as paisagens e territórios vazanteiros na Região Médio São Francisco, Bom Jesus da Lapa (BA) / Antonio Carlos de Gois Sales ; orientador: Rodrigo Penna Firme Pedrosa. - 2021.

88 f. : il. color. ; $30 \mathrm{~cm}$

Dissertação (mestrado)-Pontifícia Universidade Católica do Rio de Janeiro, Departamento de Geografia e Meio Ambiente, 2021.

Inclui bibliografia

1. Geografia e Meio Ambiente - Teses. 2. Comunidades quilombolas. 3. Uso e cobertura do solo. 4. Paisagem. 5. Vazanteiros. 6. Caatinga. I. Pedrosa, Rodrigo Penna Firme. II. Pontifícia Universidade Católica 


\section{Agradecimentos}

O presente trabalho foi realizado com o apoio da Coordenação de Aperfeiçoamento de Pessoal de Nível Superior - Brasil (CAPES) - Código de Financiamento 001

Ao meu orientador Rodrigo Penna Firme Pedrosa pelo estímulo e parceria para a realização deste trabalho.

Ao CNPq e à PUC-Rio, pelos auxílios concedidos, sem os quais este trabalho não poderia ter sido realizado.

Aos meus amigos Paulo Fevrier, William Rodrigues, Carol Carracena e minha companheira Rejane Souza por todo apoio, paciência e compreensão.

Aos meus pais, pela educação, atenção e carinho de todas as horas.

Aos meus colegas da PUC-Rio.

Aos professores que participaram da Comissão examinadora.

A todos os professores e funcionários do Departamento pelos ensinamentos e pela ajuda. A todos os amigos e familiares que de uma forma ou de outra me estimularam ou me ajudaram. 


\section{Resumo}

Sales, Antonio Carlos de Gois; Pedrosa, Rodrigo Penna Firme. USO E COBERTURA DO SOLO - DO QUILOMBO ÀS AGROVILAS: AS PAISAGENS E TERRITÓRIOS VAZANTEIROS NA REGIÃO MÉDIO SÃO FRANSCISCO, BOM JESUS DA LAPA (BA). Rio de Janeiro, 2021. 88p. Dissertação de Mestrado - Departamento de Geografia e Meio Ambiente, Pontifícia Universidade Católica do Rio de Janeiro

A região do Médio São Francisco, no interior da Bahia, no trecho do rio entre os municípios de Bom Jesus da Lapa e Serra do Ramalho é uma região onde diferentes tipos de ocupação têm sido alocados, sendo, portanto, um recorte espacial com grande potencial para compreender como as diferentes relações entre a sociedade e a natureza podem impactar na diferenciação das paisagens, sobretudo na distribuição da cobertura vegetal.

A forte presença de comunidade quilombolas vazanteira, assim como o assentamento da população atingida pela construção da barragem de Sobradinho no Projeto Especial de Colonização de Serra do Ramalho na década de 70 tornaram a região do médio São Francisco uma área de ação de diferentes práticas etnoambientais. Dessa forma, o presente estudo tem o objetivo de, a partir da utilização de geotecnologias, produzir uma análise do recorte espacial sob a ótica das mudanças de uso e cobertura do solo, de modo a comparar a trajetória a evolutiva das paisagens das comunidades quilombolas e o assentamento da população reassentada.

As métricas das paisagens apontaram uma forte diferenciação do comportamento das distribuição da cobertura vegetal, variando momentos de tendencia de perdas e ganhos de área vegetal e na presença dos tipos de fitofisionomia, sobretudo uma grande distinção entre a intensidade dos processos nos territórios das comunidades tradicionais e assentamento de Serra do Ramalho, em relação ao seus arredores.

\section{Palavras-Chave}

Comunidades Quilombolas, Uso e Cobertura do solo, Paisagem, Vazanteiros, Caatinga 


\section{Abstract}

Sales, Antonio Carlos de Gois; Pedrosa, Rodrigo Penna Firme (Advisor). LAND USE AND COVERAGE - FROM QUILOMBO TO AGROVILAS: THE LANDSCAPES AND VAZANTEIRO'S TERRITORIES IN THE REGION OF MIDDLE SÃO FRANCISCO, BOM JESUS DA LAPA (BA). Rio de Janeiro, 2021. 88p. Dissertação de Mestrado - Departamento de Geografia e Meio Ambiente, Pontifícia Universidade Católica do Rio de Janeiro.

The region of the Middle São Francisco, in the interior of Bahia, in the stretch of river between the municipalities of Bom Jesus da Lapa and Serra do Ramalho is a region where different types of occupation have been allocated, being, therefore, a spatial cut with great potential to understand how the different relationships between society and nature can impact the differentiation of landscapes, especially the distribution of vegetation cover.

The strong presence of the vazanteiras quilombola community, as well as the settlement of the population affected by the construction of the Sobradinho dam in the Serra do Ramalho Special Colonization Project in the 70s, made the middle São Francisco region an area of action for different ethno-environmental practices. Thus, this study aims to, from the use of geotechnologies, produce an analysis of the spatial cut from the perspective of changes in land use and land cover, in order to compare the evolutionary trajectory of the landscapes of quilombola and the settlement of the resettled population.

The change detection analysis was developed using images from the Landsat collection, using geotechnology tools to produce data on the distribution of vegetation cover in different spatial contexts and monitoring of temporal series. The landscape metrics showed a strong differentiation in the behavior of the distribution of vegetation cover, varying moments of trend of losses and gains of vegetation area and in the presence of types of phytophysiomy, especially a great distinction between the intensity of processes in the territories of traditional and settlement of Serra do Ramalho, in relation to its surroundings.

\section{Keywords}

Traditional Communities, Land Use and Coverage, Landscape, Vazanteiros, Caatinga 


\section{SUMÁRIO}

1- Introdução ............................................................................... 11

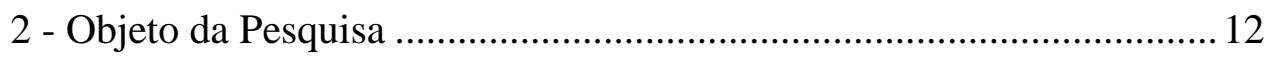

3- Área de Estudo ……………………………………………………..... 15

4 - Objetivos ..................................................................................... 18

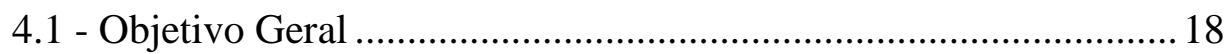

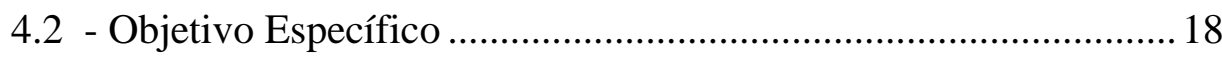

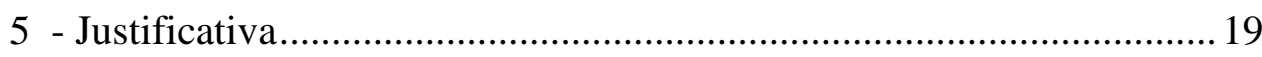

5.1 - O Velho Chico e suas paisagens..................................................... 22

6 - Fundamentação Teórico-Metodológica..................................................... 32

6.1 - Paisagem cultural .......................................................................... 32

6.2 - Ecologia da Paisagem: holismo e métricas .......................................34

6.3 - Os Sistemas de Informações Geográficas e Sensoriamento Remoto 38

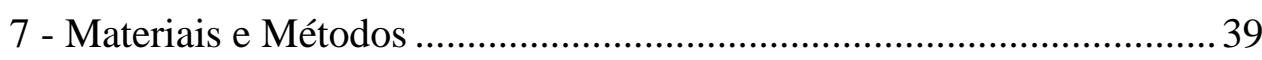

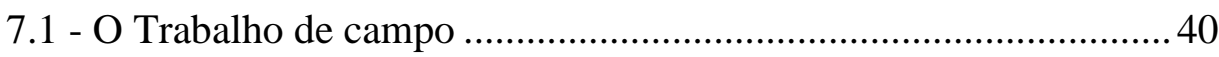

7.2 - Google Earth Engine …………………………………………...... 41

7.3 - Classes de Análises ....................................................................... 43

7.4 - Cluster K-Means............................................................................. 44

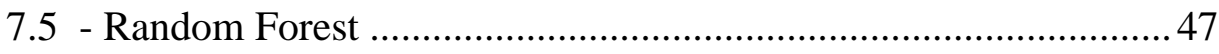

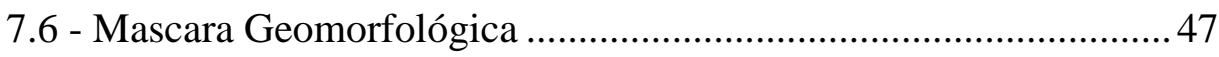

7.7 - Detecção de Mudanças .................................................................... 48

7.8 - Normalização Radiométrica ……………………………………...... 49

7.9 - Índices Vegetação e Umidade ............................................................. 49

7.10 - Classificação de Imagens ……………………………………......50

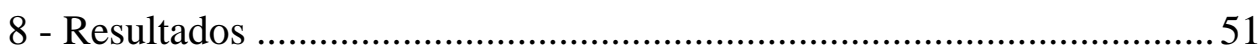




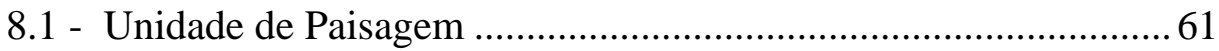

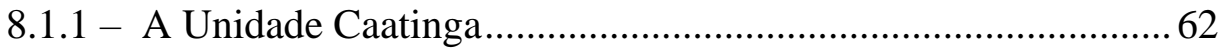

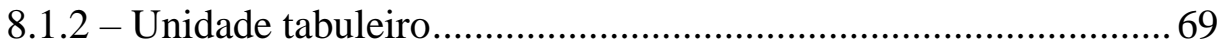

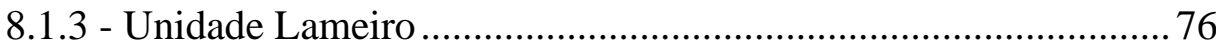

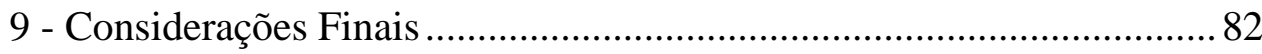

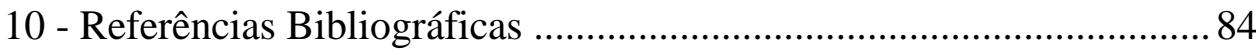




\section{LISTA DE FIGURAS}

Figura 1- Bom Jesus da Lapa à direita, e Serra do Ramalho à esquerda Fonte: COVASF (2020) 13

Figura 2 - Alagados / Lameiros em Araçá/Cariacá - Fonte: Antonio Sales .26

Figura 3 - Tabuleiro em Lagoa do Peixe, visto em direção ao Rio São Francisco - Fonte: Antonio Sales 27

Figura 4 - Caatinga em Lagoa do Peixe - Fonte: Antonio Sales 28

Figura 5 - Mapa de Uso Tradicional e Geomorfologia Fluvial - Fonte: IBGE ,2001 29

Figura 6 - Interface Google Earth Engine 42

Figura 7- Sensores do programa Landsat e suas respectivas faixas de cobertura espectral 44

Figura 8 - Fluxograma metodológico - Fonte: Antonio Sales (2021)...... 46

Figura 9 - Exemplo do método Random Forest........................................ 47

Figura 10- Mapa de Cobertura Vegetal - 1972 ........................................5 52

Figura 11- Mapa de evolução de cobertura vegetal da área de estudo ......55

Figura 12 - Gráfico da evolução distribuição de cobertura vegetal em Serra do Ramalho 55

Figura 13 - Gráfico da evolução distribuição de cobertura vegetal nas Comunidades Quilombolas 57

Figura 14 - Gráfico da evolução de ganhos e perdas de áreas florestadas área de estudo, comunidades quilombolas e assentamento Serra do Ramalho 58

Figura 15 - Gráfico da evolução de ganhos e perdas de áreas florestadas área de estudo, comunidades quilombolas e assentamento Serra do Ramalho 59

Figura 16 - Mapa de evolução de cobertura vegetal da unidade Caatinga 64

Figura 17- Gráfico da evolução distribuição de cobertura vegetal no assentamento Serra do Ramalho / Unidade de paisagem Caatinga 65

Figura 18- Gráfico da evolução distribuição de cobertura vegetal nas comunidades quilombolas / Unidade de paisagem Caatinga 66

Figura 19- Gráfico da evolução de detecção de mudanças de cobertura vegetal nos diferentes recortes, em \% da área da unidade de paisagem Caatinga 67 
Figura 20 - Mapa de evolução de cobertura vegetal da unidade tabuleiro71

Figura 21- Gráfico da evolução distribuição de cobertura vegetal em Serra do Ramalho / Unidade de paisagem Tabuleiro. .72

Figura 22- Gráfico da evolução distribuição de cobertura vegetal na Comunidades Quilombolas / Unidade de paisagem Tabuleiro 73

Figura 23- Gráfico da evolução de detecção de mudanças de cobertura vegetal nos diferentes recortes, em \% da área da unidade de paisagem Tabuleiro74

Figura 24- Mapa de evolução de cobertura vegetal da unidade Lameiro.. 77

Figura 25- Gráfico da evolução distribuição de cobertura vegetal em Serra do Ramalho / Unidade de paisagem Lameiro. .78

Figura 26 - Gráfico da evolução distribuição de cobertura vegetal em Comunidades Quilombolas / Unidade de paisagem Lameiro 79

Figura 27 - - Gráfico da evolução de ganhos e perdas de áreas florestadas área de estudo, comunidades quilombolas e assentamento Serra do Ramalho / Unidade de paisagem Lameiro .80 


\section{LISTA DE QUADROS}

Quadro 1 - Métricas da paisagem das áreas de estudo, comunidades

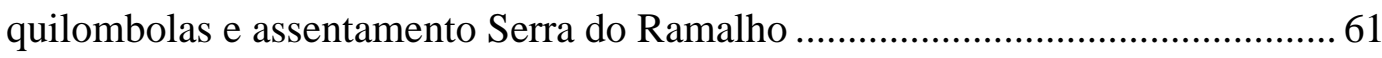

Quadro 2 - Distribuição das unidades de paisagem na área de estudo ...... 62

Quadro 3 - Métricas da paisagem das áreas de estudo, comunidades quilombolas e assentamento Serra do Ramalho - Unidade de paisagem Caatinga 69

Quadro 4 - - Métricas da paisagem das áreas de estudo, comunidades quilombolas e assentamento Serra do Ramalho - Unidade de paisagem Tabuleiro 


\section{1- Introdução}

No Brasil, a parte final a década de 70 foi marcada pelo período de ditadura militar, caracterizado, dentre outros aspectos, por uma agenda de grandes projetos de desenvolvimento impulsionados pelo poder do Estado. O ideal subjacente era conectar as várias regiões do Brasil, ainda predominantemente rural, por meio de projetos de infraestrutura como estradas, ferrovias, pontes, assim como ampliar a distribuição e produção de insumos básicos para o processo de industrialização (diga-se de passagem, muito atrasado em relação aos países tidos como primeiro mundo). Este ideal de desenvolvimento gera uma série de impactos positivos, no entanto, também cria uma série de problemas ambientais e conflitos socioambientais, tais como os demonstrados pelo movimento social dos afetados por barragens de usinas hidrelétricas.

Uma das consequências da expansão destes projetos de cunho desenvolvimentista e técnico-científico foi o surgimento de organizações e movimentos sociais de resistência aos mesmos. Neste contexto, a redemocratização e a promulgação da constituição de 1988 marca o início formal/legal, ou melhor, inicia a judicialização e a formação do direito constitucional de múltiplas demandas da sociedade, em particular, para o que nos interessa neste estudo, a abertura política para a concessão de títulos de terras para grupos marginalizados no processo de expansão desenvolvimentista.

Os impactos socioambientais derivados das implementações de barragens são dados pela multiplicidade de nichos afetados pela implementação e operação destes empreendimentos que acabam por afetar o equilíbrio de todo um ecossistema. Grandes fragmentos vegetais são inundados, impactando na disponibilidade da vegetação nativa e nos habitats de várias espécies da fauna. No 
campo social o impacto mais intenso se dá primeiramente pela a supressão de localidades, o lugar de suas memórias e reprodução da cultura de várias populações, a posteriori o realocamento dessas comunidades passa por um processo de reacomodação, no qual novas relações socioambientais são postas pela situação que impõe, e essa relação, que necessariamente se dá no espaço, nele moldará novas formas e paisagens. (NASCIMENTO e SILVA, 2011)

\section{2 - Objeto da Pesquisa}

A região do Médio São Francisco, interior da Bahia, no trecho do rio entre os municípios de Bom Jesus da Lapa e Serra do Ramalho é uma região onde tipos de ocupações diferenciados se alocaram, sendo dessa forma, um recorte espacial com grande potencial para compreender como as diferentes relações entre sociedade e natureza podem impactar na diferenciação das paisagens. A análise deste recorte espacial sob a perspectiva das mudanças de uso e cobertura do solo contribuem para uma área que não tem um apelo teórico acadêmico a priori, sobretudo por seu caráter variado de ocupação humana em uma matriz ambiental comum.

As comunidades ribeirinhas e populações realocadas a margem do principal curso d'agua da região nordeste do país, o Rio São Francisco, tem um modo de vida relacionado historicamente com o ciclo de inundação, essa relação entre as comunidades acaba por demonstrar um importante relacionamento entre cultura, identidade e ambiente. $\mathrm{O}$ melhor entendimento da produção da paisagem dessa região do médio São Francisco requer uma investigação aprofundada destas relações. O caso da região Bom Jesus da Lapa/ Serra do Ramalho é um importante estudo de caso para entender como abordagem do Estado à estas populações ribeirinhas acabou por impor um relacionamento que se materializam na paisagem, impactando comunidades e ambiente. 
Deste modo, nessa região do "Velho Chico" com a localização dos territórios certificados ${ }^{1}$ das comunidades quilombolas em uma margem (Bom Jesus da Lapa) e os assentamentos do Projeto Especial de Colonização em outra (Serra do Ramalho), podem explicitar como se dá a relação entre ser humano e natureza, especialmente considerando um dos principais focos para esse entendimento se encontra na análise dos aspectos fundamentais para a perpetuação da vida no qual o cotidiano dessas comunidade é constituído em torno. Tal região tem potencial para a partir da busca da espacialização das relações ecológicas e do entendimento dos processos de gênese da paisagem, oportunidade de comparar o desenvolvimento das relações de uso da terra, de transformação de uma paisagem compartilhada, por meio de dois projetos distintos.

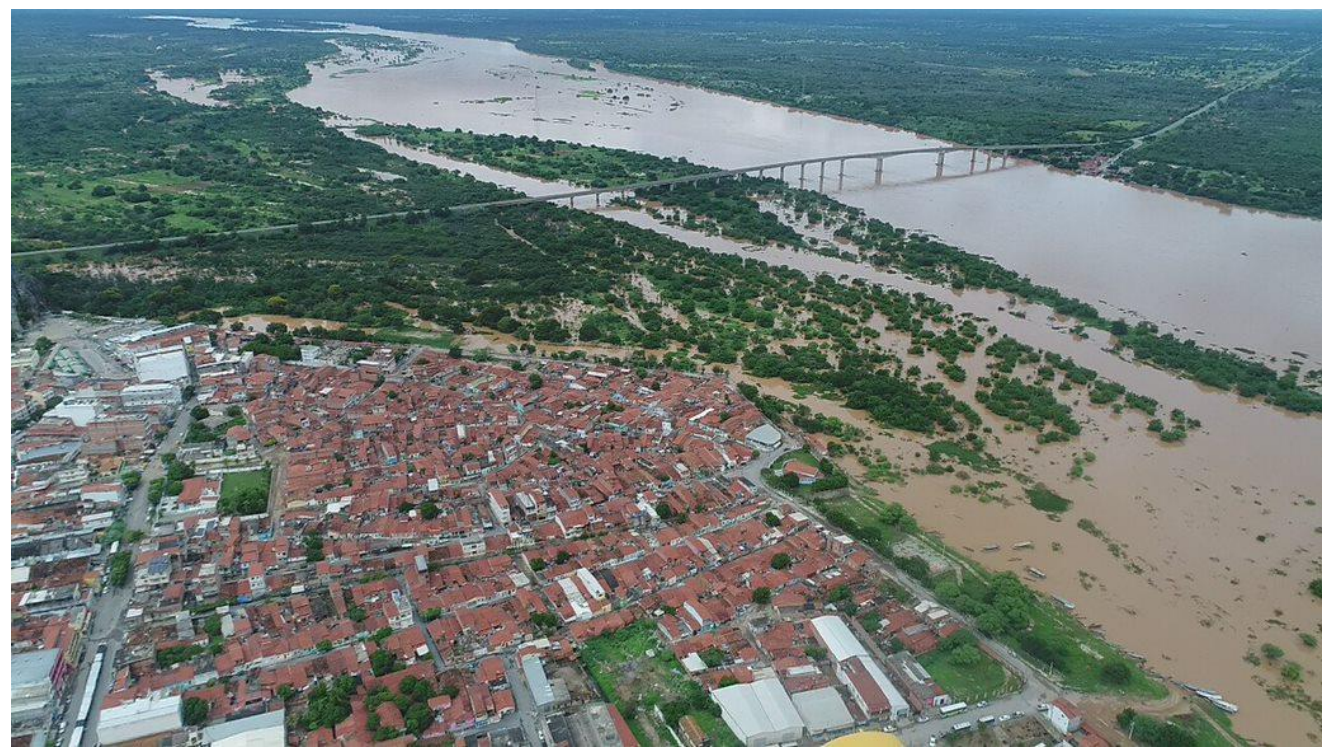

Figura 1- Bom Jesus da Lapa à direita, e Serra do Ramalho à esquerda - Fonte: COVASF (2020)

O modo de vida das comunidades ribeirinhas do São Francisco é comumente chamado de vazanteiro ou barranqueiros, que remete a séculos de práticas

1 Certificação da Fundação Cultural Palmares, um processo antes da titulação do território. 
ambientais das populações que ocuparam e ainda ocupam este trecho, desta planície fluvial e regulam seu cotidiano a partir dos ciclos fluviais, assim como ocorrem nas comunidades caboclas na Amazônia (ADAMS et al., 2005). Dessa forma, tais comunidades são parte importante para a conjuntura socioambiental dos municípios de Bom Jesus da Lapa e Serra do Ramalho, e sobretudo para a conservação dessa região do ecótono Caatinga-Cerrado e principalmente para a qualidade ambiental do Rio São Francisco.

As análises temporais de mudança de uso do solo podem servir como indicador sobre como o modo de vida vazanteiro vem se mantendo ao decorrer do tempo. Sobretudo considerando a evolução da estrutura fundiária da região, com a implementação de assentamentos rurais e reconhecimento dos territórios das comunidades quilombolas às margens do rio. Considerando as diferentes formas de ação do Estado às populações de matriz étnicas diferentes, no entanto com práticas ambientais extremamente semelhantes.

Este estudo buscará investigar a transformação da paisagem cultural através de marcos temporais relativos à situação fundiária pra entender como as comunidades, e principalmente, a paisagem reagem a processos endógenos e exógenos. E desta maneira, comparar as trajetórias das mudanças de uso do solo a partir da análise de métricas da paisagem geradas a partir do processamento de dados gerados por aplicação de métodos de sensoriamento remoto. Ao decorrer dessa pesquisa foi feito um esforço para buscar entender como o a ação prolongada das práticas ambientais da cultura quilombola/vazanteira, assim como o projeto de agrovilas/reassentamento contribuem para a realidade socioambiental da planície de inundação do Rio São Francisco e áreas adjacentes, na região de Bom Jesus da Lapa/Serra do Ramalho. 


\section{3- Área de Estudo}

A área de estudo, delimitada para o processamento de imagens, abrange um trecho representativo de todas as unidades de paisagens da cultura vazanteira (Alagados / Lameiros, tabuleiros e caatinga), incluindo cinco comunidades quilombolas ao longo e do Projeto Especial de Colonização de Serra do Ramalho, em um trecho de $103 \mathrm{Km}$ do Rio São Francisco. Desse modo foi determinado um buffer de $20 \mathrm{Km}$, a partir das margens do leito fluvial, compondo uma área de 440.294 hectares.

Localizada no sertão do Estado da Bahia, na região do Médio São Francisco, a área compreende parte de três munícipios, situados em zona de regime climático semiárido, marcados por baixa pluviosidade. Tem seu relevo caracterizado pela presença de Depósitos Sedimentares Quaternários, ao longo da planície de inundação dos principais rios da região, que sem encontram encaixados nos Crátons Neoproterozóicos, que dominam grande parte da Região Nordeste do Brasil (IBGE,2021).

Outra característica que se destaca na área de estudo é a presença de dois biomas: a Caatinga e o Cerrado, que compõem $91,2 \%$ e $8,8 \%$ respectivamente, e atribuem a essa área as características de ecótono que impactam diretamente nas relações ecossistêmicas e ampliam a gama de serviços ambientais prestados pela estruturas da paisagem.(IBGE,2021). A área apresenta solos do tipo Cambissolos Háplicos, Latossolo Amarelo, Neossolo Flúvico, Neossolo Quartzarênico, Planossolo Háplico (EMBRAPA,2018)

Na esfera social, o histórico de ocupação da área de estudo se entrelaça com a História do desenvolvimento nacional, no período colonial a coroa portuguesa incentivou a colonização das margens do Rio São Francisco através da doação de terrenos e intensificou as atividades agropastoril, que objetivava suprir as demandas das cidades de Minas Gerais que cresciam enormemente devido ao ciclo do ouro na região. Num passado mais recente a região é marcada pela imposição do Projeto 
Especial de Colonização Serra do Ramalho que trouxe as populações afetadas pela inundação da barragem de Sobradinho, em 1972.

Assim, o relacionamento ambiental das comunidades quilombolas Lagoa do Peixe e Araçá/Cariacá e a conjunta ambiental da bacia do Rio São Francisco levantaram a questões tais como: Como as práticas ambientais tradicionais se inserem no contexto ambiental da planície fluvial do Rio São Francisco? Qual é o papel das diferentes atividades ao longo da planície de inundação? E sua relação com a preservação do Rio São Francisco? Estas são perguntas que a presente pesquisa pretende responder. 


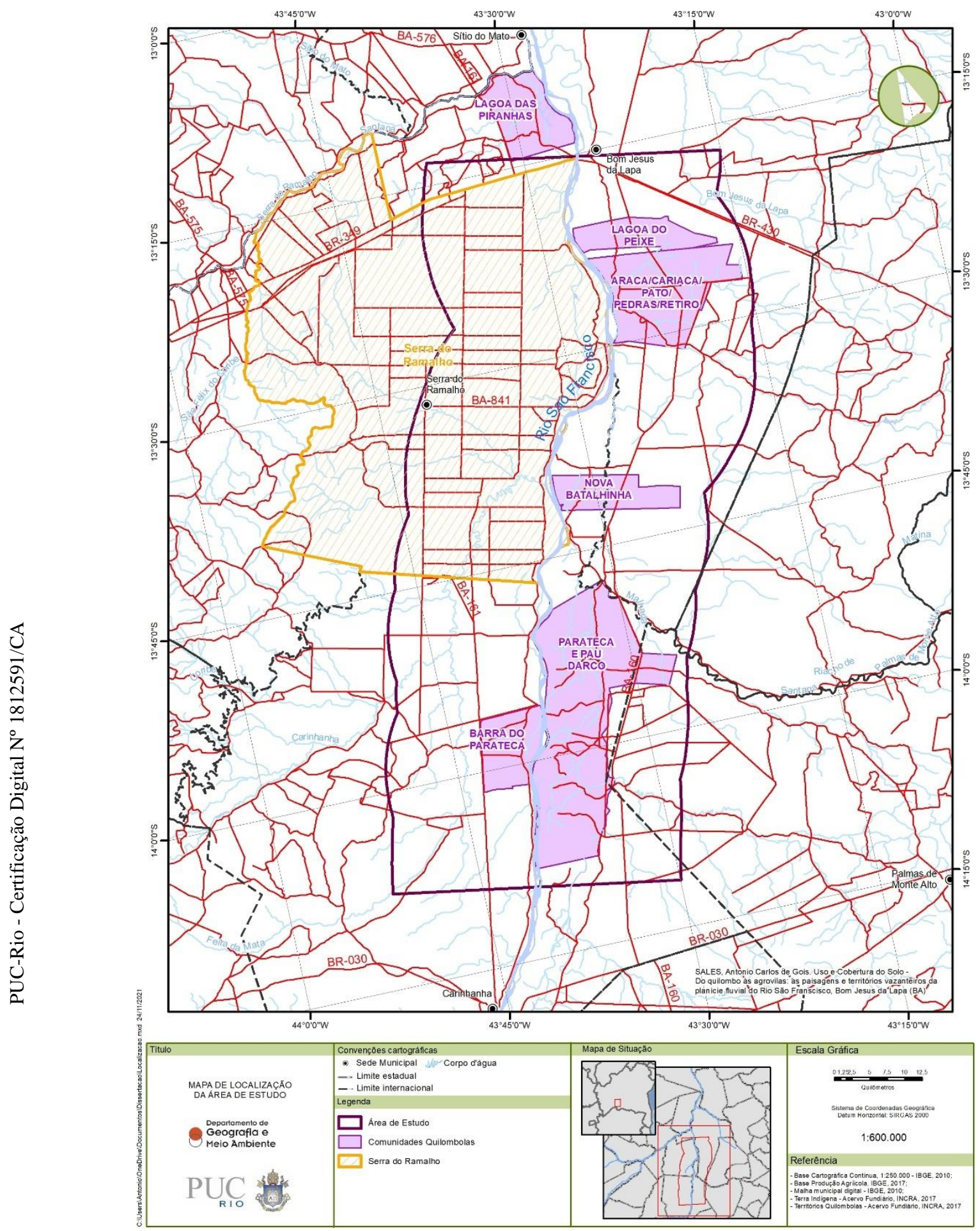

Figura 2 - Mapa de Localização 


\section{4 - Objetivos}

\section{1 - Objetivo Geral}

Avaliar e comparar as trajetórias ambientais que se dão ao nível da paisagem a partir das análises da evolução da cobertura vegetal na planície fluvial do Rio São Francisco, e buscar identificar as possíveis relações com eventos políticosadministrativos atuam na estrutura fundiária da região do Médio São Francisco, nas proximidades de Bom Jesus da Lapa - BA, sobretudo nas comunidades quilombolas e no Projeto Especial de Colonização Serra do Ramalho presentes na região. O foco é buscar o entendimento, a partir de uma análise comparativa da trajetória dos diferentes modos de ocupação, a partir da detecção de mudanças nas estruturas da paisagem tendo como base análise de imagens, levantamentos de campo e dados secundários, utilizando o modelo do territorial das comunidades quilombolas/vazanteiras. Dessa forma, buscando compreender o processo de evolução das paisagens do sistema rio-planície, compreendido em uma área de influência de $20 \mathrm{Km}$ de distância do Rio São Francisco, compreendendo 440 mil hectares entre os municípios. presentes em Bom Jesus da Lapa, Araçá/Cariacá, da Lagoa do Peixe e Nova Batalhinha, e do assentamento rural do Projeto de Especial de Colonização em Serra do Ramalho.

\section{2 - Objetivo Específico}

- Detectar as mudanças na estrutura de cobertura vegetal nos diferentes modelos de ocupação do solo 


\section{5 - Justificativa}

As técnicas de geoprocessamento, atualmente, alcançaram um nível qu em termos de aplicabilidade e potencial de análise, permitem o detalhamento dos modelos de representação de sistemas espaciais, sobretudos os mapeamentos de sistemas ambientais. Nesse sentido, a Ecologia da Paisagem, um campo acadêmico ainda em ampla evolução por trazer notáveis contribuições para o estudo das relações ambientais. Principalmente, por ter como faceta a análise da heterogeneidade espacial como força propulsora dos padrões e processos ecológicos. A Ecologia da Paisagem investiga os processos antrópicos e ecológicos que atuam como modeladores da paisagem a partir do entendimento da dinâmica da diversidade espacial e da ação humana como agente de gênese da paisagem. (LANG e BLASCHKE,2009)

A modelagem de sistemas ambientais baseasse na abstração dos processos ambientais, dessa forma o Geoprocessamento colabora para a representação dos processos da paisagem, justamente pela perspectiva dada aos métodos quantitativos (descritivos) empregados na caracterização da estrutura de paisagens. A utilização de técnicas de análise e modelagem dinâmica de paisagem é um importante suporte para o entendimento das atividades pretéritas, assim como um aprimoramento do planejamento de ações futuras, notadamente considerando a tendencia de fragmentação dos ecossistemas originais, e pelo modo de ocupação territorial presentes nas sociedades contemporâneas. (FERNANDES,2016)

A generalização tem um caráter fundamental na prática científica, sobretudo na elaboração de modelos sistêmicos pois é complemente impossível especificar todas as nuances dos processos da natureza. Dessa forma, a delimitação dos processos fundamentais para a modelagem do fenômeno estudado torna-se um ponto nevrálgico do processo de análise, pois depende do amplo conhecimento das variáveis inserida em determinado sistema. (FERNANDES, 2016b)

A descrição de uma paisagem geográfica pode ser abordada com uma unidade ou variação de uma unidade, mas sempre se dará a partir de uma 
generalização que emerge da observação de cenas individuais, e é sempre caracterizada por processos comparativos. (SAUER, 1925). Dessa forma, a paisagem é apreendida pelo geógrafo como uma seleção de características genéricas guiada por um julgamento sobre estas.

O critério é a própria escolha, condicionada, como toda arte econômica, pelo conhecimento da situação real. Esta seleção é sem dúvida conduzida com inteligência, mas não com a aplicação de um critério filosófico e só é justificada por ela mesma. Por essa razão nós falamos da sensibilidade ou instinto do homem educado." (Croce apud Sauer, p.25)

O valor cultural da paisagem foi reconhecido como patrimônio mundial pela Convenção Mundial da UNESCO em 1992 visando a preservação da memória e da paisagem cultural, definida como "um combinado do trabalho da natureza e do homem". A termo paisagem cultural (kulturlandschaft) tem sido usado na Geografia desde o século XIX, e sua origem está associada escola acadêmica de pensamento geográfico alemã, que foram os primeiros a associarem o trabalho humano às formas das paisagens. (LANG \& BLASCHKE, 2009)

A comunidades tradicionais por sua relação ancestral com a terra, além de serem um dos principais elementos produtores de paisagem, é também uma fonte de conhecimentos vindo de uma longa história de relacionamento com o meio que os envolve. Dessa forma, o entendimento da variação das paisagens a partir da perspectiva das comunidades tradicionais comunidades pode levar a uma compreensão de como a cultura impacta na evolução das paisagens.

$\mathrm{Na}$ superfície terrestre há uma imensa diversidade cultural humana, correspondendo a uma igualmente ampla diversidade de territórios, e suas respectivas heterogeneidades de territorialidades, com dimensões e conteúdo específicos (HAESBAERT,2007). Assim, diferentes manifestações de territorialidades, por muitas vezes, se apresentam como conflitos causados, sobretudo, pelas diferentes formas de se relacionar com o espaço, das diferentes formas de co-construir a paisagem.

O desenvolvimento do processo de conscientização à respeito das interações ambientais do homem e a elevação dos debates do impactos ambientais 
colocou em foco a questão da produção e o manejo sustentável dos recursos, dessa forma revalorizando às populações tradicionais, e sobretudo ressaltada a importância dos patrimônios culturais, entre eles a paisagem.

Como apontado por Arruda (2007):

Tornou-se, portanto, mais evidente que as populações "tradicionais"1, seringueiros, castanheiros, ribeirinhos, quilombolas, mas principalmente as sociedades indígenas, desenvolveram através da observação e experimentação um extenso e minucioso conhecimento dos processos naturais e, até hoje, as únicas práticas de manejo adaptadas às florestas tropicais (MEGGERS, 1977; DESCOLA, 1990; ANDERSON \& POSEY, 1990). Embora estas populações corporifiquem um modo de vida tradicionalmente mais harmonioso com o ambiente, vêm sendo persistentemente desprezadas e afastadas de qualquer contribuição que possam oferecer à elaboração das políticas públicas regionais, sendo as primeiras a serem atingidas pela destruição do ambiente e as últimas a se beneficiarem das políticas de conservação ambiental (ARRUDA, 2007 p.83)

Desta forma os estudos etnoambientais das comunidades tradicionais, especialmente pelo conhecimento acumulado ao decorrer da história do modo de vida dessas populações, pode contribuir para reformularmos os paradigmas da relação homem/ambiente nas sociedades modernas. Tais comunidades, através do sentimento de pertencimento e de subsistência, desenvolvem em uma parcela do espaço geográfico um relacionamento com o ambiente, em que território e identidade se mesclam e afloram nas paisagens com o resultado de suas práticas culturais e ambientais.

Ao longo do Rio São Francisco, especialmente em Bom Jesus da Lapa, há a presença de comunidades tradicionais quilombolas que vem reproduzindo em seus territórios, durante séculos, práticas ambientais relacionadas ao modo de vida de uma cultura, que se manifestam na paisagem.

Na planície fluvial do Rio São Francisco ocorrem a presença de diversos usos das práticas culturais tradicionais à atividade de monocultura agroexportadora, além de um complexo arranjo das fitofisionomias vegetais, dado o fato da região ser área de ecótono, em micro-escala, pelas variações do sistema rio-planície, e em mesoescala pela transição Caatinga-Cerrado. Desta forma, se faz necessário o entendimento do arranjo da cobertura vegetal e de sua dinâmica, para o 
embasamento a ações que visem a mitigação dos impactos das atividades humanas incidentes sobre ambiente, e a conservação do principal corpo hídrico da região Nordeste.

A presente pesquisa pretende entender, a partir da detecção da evolução das métricas da paisagem, ao longo do tempo, como a relação do ser humano com seu ambiente é impactada por eventos impulsionados por políticas fundiárias, e desse modo, identificar os processos de produção de paisagem, sob a perspectiva pragmática da antropologia materialista. Assim propõe-se interpretar, como base em experiencia de campo e literatura, como e o porquê as comunidades reagem a determinados eventos, tratando dessa questão em um contexto socioambiental particular, dotado de características específicas, no caso, numa área compreendida pela planície de inundação do Rio São Francisco, no trecho do limítrofe e suas áreas adjacentes, entre os municípios de Bom Jesus da Lapa e Serra do Ramalho, compreendendo os territórios das Comunidades Quilombolas Araçá/Cariacá, Lagoa do Peixe e Nova Batalhinha em de Bom Jesus da Lapa, assim como a área do Projeto Especial de Colonização implementado em Serra do Ramalho, localizado no interior do Estado da Bahia.

\section{1 - O Velho Chico e suas paisagens}

Talvez o processo geográfico mais comum e intuitivo na história das sociedades seja o povoamento ao redor dos corpos hídricos. Em todas as partes do globo a humanidade construiu uma enorme gama de relacionamentos ambientais em quais com os recursos hídricos são o fator estruturante de suas culturas, resultando numa gigantesca variedade de paisagens.

O processo de escolha da área de estudo deu-se entre avanços e recuos pois, como o interesse pela área se deu por após uma atuação profissional com a finalidade de contribuir na elaboração do estudo referente uma etapa do processo de licenciamento ambiental de uma usina fotovoltaica, em Bom Jesus da LapalBA. Dessa forma, o interesse pela área nasce condicionado, e restrito, no entanto cabe ao geógrafo, a busca por um ponto de vista que enquadre em forma de síntese os fenômenos da paisagem. 
As comunidades ribeirinhas situadas a margem do principal curso d'agua da região nordeste do país, o Rio São Francisco, tem um modo de vida relacionado historicamente com o ciclo de inundação, essa relação entre as comunidades tradicionais acaba por desvelar um importante relacionamento entre cultura, identidade e ambiente, sendo necessária uma investigação mais aprofundada para o melhor entendimento da produção da paisagem dessa região do médio São Francisco. O caso da região de Bom Jesus da Lapa/ Serra do Ramalho expõe como o entendimento do Estado destas populações ribeirinhas acaba por impor um relacionamento que se materializam na paisagem, impactando nas comunidades e no ambiente.

A geografia baseia-se, na realidade, na união dos elementos físicos e culturais da paisagem. O conteúdo da paisagem é encontrado, portanto, nas qualidades físicas da área que são importantes para o homem e nas formas do seu uso da terra, em fatos de base física e fatos da cultura humana. (SAUER,1925)

Com a localização dos territórios certificados das comunidades quilombolas em uma margem (Bom Jesus da Lapa) e os assentamentos do Projeto Especial de Colonização em outra (Serra do Ramalho) e a presença de latifúndios do agronegócio, produzem um mosaico de paisagens, e em algumas regiões as contradições e tensões tornam-se latentes, e se exprimem em intensos impactos socioambientais.

Na Região do Médio São Francisco, interior da Bahia, no trecho do rio entre os municípios de Bom Jesus da Lapa e Serra do Ramalho, os processos de ocupação fundiária distintos foram induzidos pelo Estado, a partir de abordagens diferenciadas baseadas em entendimentos da cultura, acarretando em impactos socioambientais drásticos, profundamente enraizados na paisagem desta região de uma identidade e permanência de uma tradicionalidade. (SOUZA e BRANDÃO,2011)

A cultura vazanteiras, se espraia por todo o Médio São Francisco, e seus territórios são caracterizados pela presença de três grandes unidades de paisagens para a descrição dos territórios: Os Alagados / Lameiros , o Tabuleiro e a Caatinga, que se apresentaram como áreas de usos tradicionais e de domínio de processos 
geomorfológicos associados aos ciclos de enchentes do rio .(DUPRAT e PERREIRA,2003). Numa relação muito próxima do entendimento de Dardel sobre como o homem pode ser "esmagado" pelo ambiente.

É importante não se acreditar no erro de que a espacialização geográfica se produz somente em virtude de um comportamento ativo. É o caso onde o homem é agenciado pelo ambiente geográfico: ele sofre a influência do clima, do relevo, do meio vegetal. Ele é montanhês na montanha, nômade na estepe, terrestre ou marinho. A natureza geográfica o lança sobre si mesmo, dá forma a seus hábitos, suas ideias, às vezes a seus aspectos somáticos. Ocorre que a floresta "esmaga" o homem, que a floresta virgem o "asfixia", que a landa o inclina à melancolia. Ocasionalmente o homem encontra essa passividade. (DARDEL, 1952)

No município de Serra do Ramalho, margem oposta às comunidades quilombolas de Bom Jesus da Lapa, encontra-se o assentamentos do Projeto Especial de Colonização, que foi idealizado para receber as populações também vazanteiras que foram reassentadas devido a construção da barragem de Sobradinho que inundou milhares de hectares, deslocando dezenas de povoados com as clássicas “promessas de um vida melhor”.(INCRA,1972)

A criação de um polo desenvolvimento agrícola focado em retrair o êxodo rural no sertão baiano, foi pensada por uma empresa paulistana, com um viés civilizatório, num formato de agrovilas, num processo de urbanização do campo. Dessa forma, as populações retiradas das margens do rio foram inseridas em um processo de "desenvolvimento agrário", no qual tiveram que se desfazer dos seus modos de vida, sendo forçadas a viverem nos sistemas de agrovilas e abandonando os antigos hábitos vazanteiros, como a pesquisa de ESTRELA (2000) apontou:

A nova organização espacial foi criada obedecendo a uma articulação do rural e do urbano. Esta articulação está ancorada na divisão lote/agrovila, fator dos mais ilustrativos dos descompassos entre os agentes planejadores do Estado e os beraderos sanfranciscanos.

Nessa região do São Francisco com a localização dos territórios certificados das comunidades quilombolas em uma margem (Bom Jesus da Lapa) e os assentamentos do Projeto Especial de Colonização em outra (Serra do Ramalho), o 
Estado, a partir de políticas públicas fundiárias, interfere nos destinos de diversas comunidades ribeirinhas. Sobretudo, considerando o primeiro grupo assentados na Serra do Ramalho, que era formado por comunidades desalojadas pela construção da barragem de Sobradinho, a maior do Rio São Francisco. (ESTRELA, 2000b)

Pode-se dessa forma, entender que em uma margem a cultura quilombola manteve os hábitos de uso e a paisagem cultural vazanteira encontra-se preservada, e todo o seu processo evolutivo ao longo do tempo, na planície de inundação, já na paisagem da margem oposta, que é fruto de uma imposição de práticas urbanas às comunidades tradicionalmente vazanteiras, um grande processo de alijamento de sua cultura, de suas paisagens.

A agricultura das comunidades depende das condições climáticas e principalmente dos períodos de cheias do São Francisco, já que as margens do rio são as áreas mais férteis do território. Os Alagados / Lameiros, como são chamados os diques marginais são áreas destinadas as roças comunitárias, atividade agrícola de manejo rústico, utilizando sistema de coivara, sem uso de mecanização ou de irrigação, surgindo assim a primeira unidade de paisagem apontada pelos quilombolas. Também conta com a presença de meandros abandonados, e pequenas lagoas que se encontram secas a maior parte ao ano. Os Alagados / Lameiros apresentam de uma fitofisionomia mista de caatinga arbórea de médio porte e arbustiva, a região também é caracterizada pela presença de sedimentos finos que são depositados ao recuo das enchentes. 


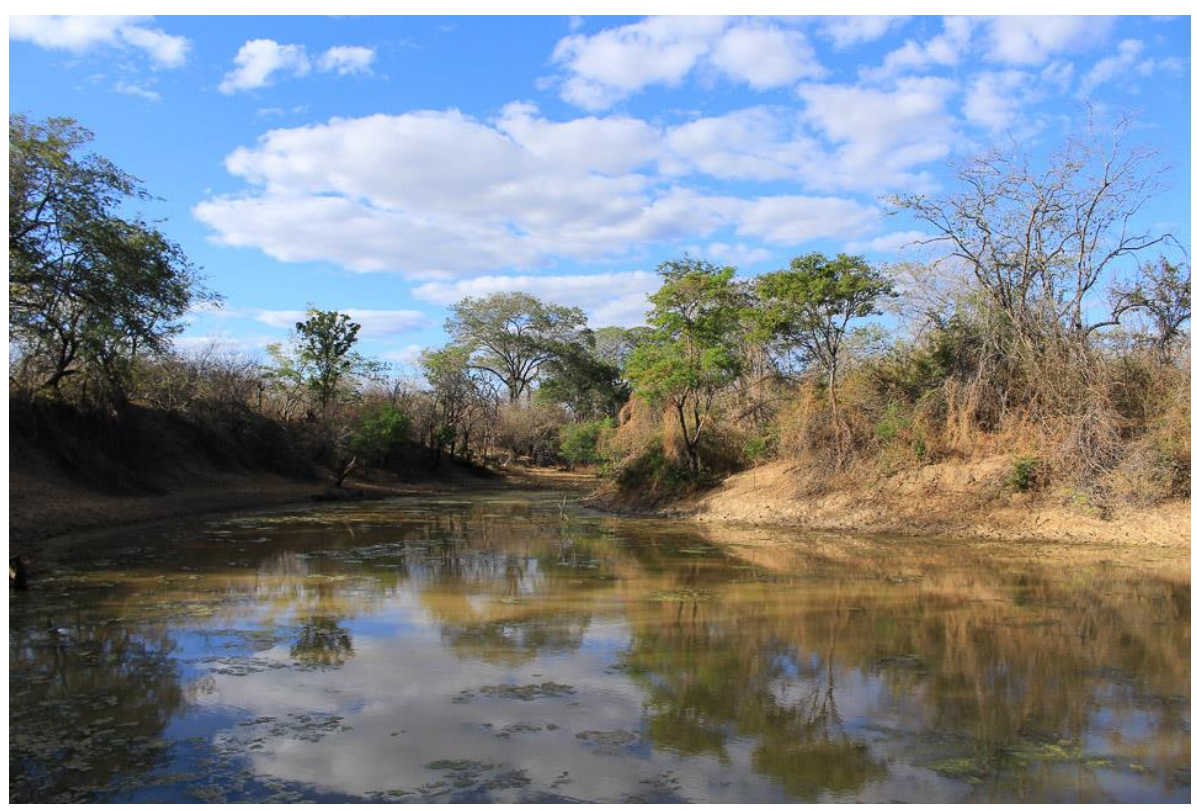

Figura 2 - Alagados / Lameiros em Araçá/Cariacá - Fonte: Antonio Sales

Outra unidade de paisagem apresentada pelos habitantes dos quilombos, surgida no decorrer da aplicação das entrevistas foram os chamados Tabuleiros/Sequeiros que correspondem, a área de planícies fluvial, ou leito maior, que assim como os diques está sujeita a inundação. Área de deposição de sedimentos mais grosseiros constitui uma faixa arenosa, tornando-se a principal área de assentamento de residências e de plantio de culturas mais resistentes a condição climática do semiárido e área de pastagem no período mais úmido do ano.

Os Tabuleiros são caracterizados pela presença de vegetação de pastagem os tabuleiros, contam com a presença de arbustos e arvores esparsadas, a presença marcante de grandes faixas de areia delimitam significativamente os limites dessa unidade de paisagem. 


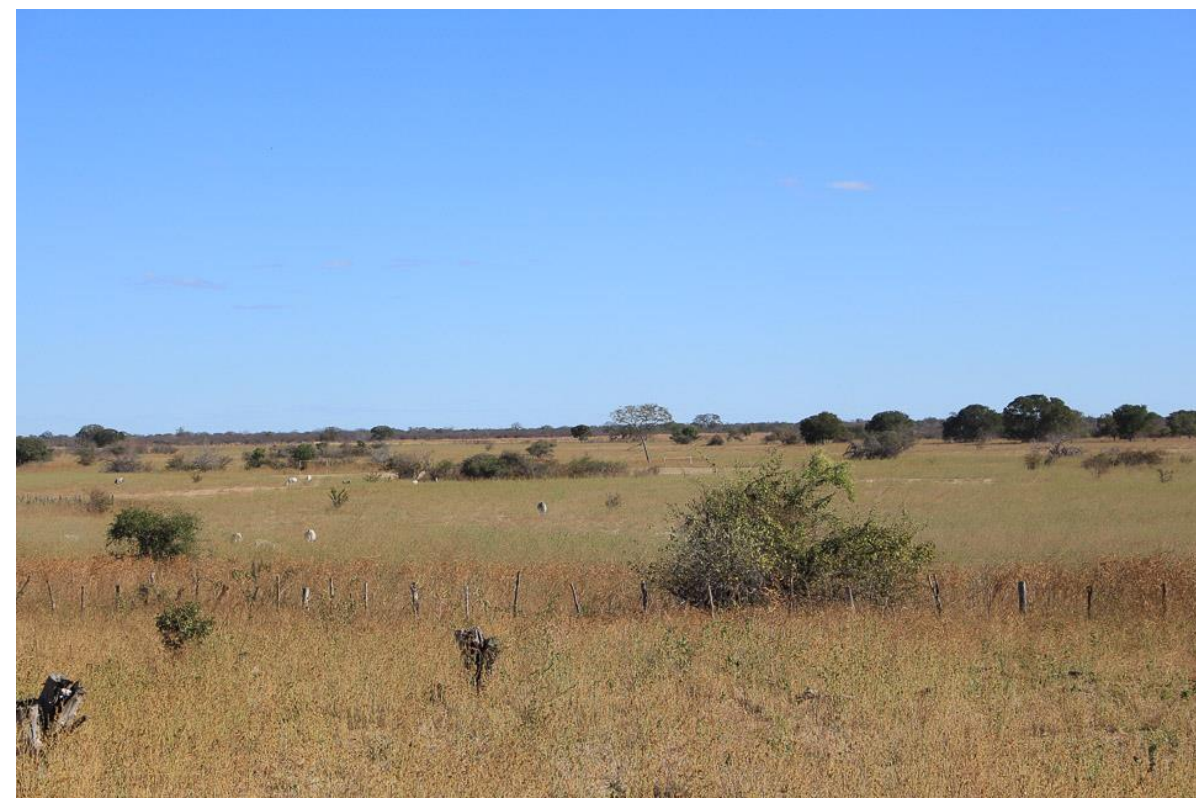

Figura 3 - Tabuleiro em Lagoa do Peixe, visto em direção ao Rio São Francisco - Fonte: Antonio Sales

A terceira unidade de paisagem do modo de vida quilombola é a: Caatinga. Além de se tratar da área com vegetação típica do semiárido, representam o limite entre o leito maior excepcional e as bordas da formação geomorfológica depressão alto-médio do São Francisco. (IBGE, 2021) E por se tratar desse limite, nos períodos de grandes cheias, atuam como refúgio nos momentos de grande inundação. Assim como reserva de pasto para os períodos de estiagem. A Caatinga também é compreendida como uma área dedicada como herança para "os que vão nascer, os que vão crescer", tendo um regime de gestão território diferenciado, sendo necessária a aprovação da associação para a abertura de novas roças. (INCRA, 2009)

A Depressão do Alto- Médio São Francisco, a unidade de paisagem Caatinga é representado por uma área de planície constituída por rampas arenosas convergentes para o Rio São Francisco, tendo como característica a pouca fertilidade do solo. As principais características da vegetação da Caatinga são, solo raso e pedregoso, árvores baixas, troncos tortuosos e que apresentam espinhos e folhas que caem no período da seca (com exceção de algumas espécies, como o juazeiro). Destacam-se neste bioma, as seguintes espécies: bromélias, xique-xique, 
mandacaru, embiratanha, acácia, juazeiro, macambira, maniçoba, umbu e mimosa.

(IBGE,2021)

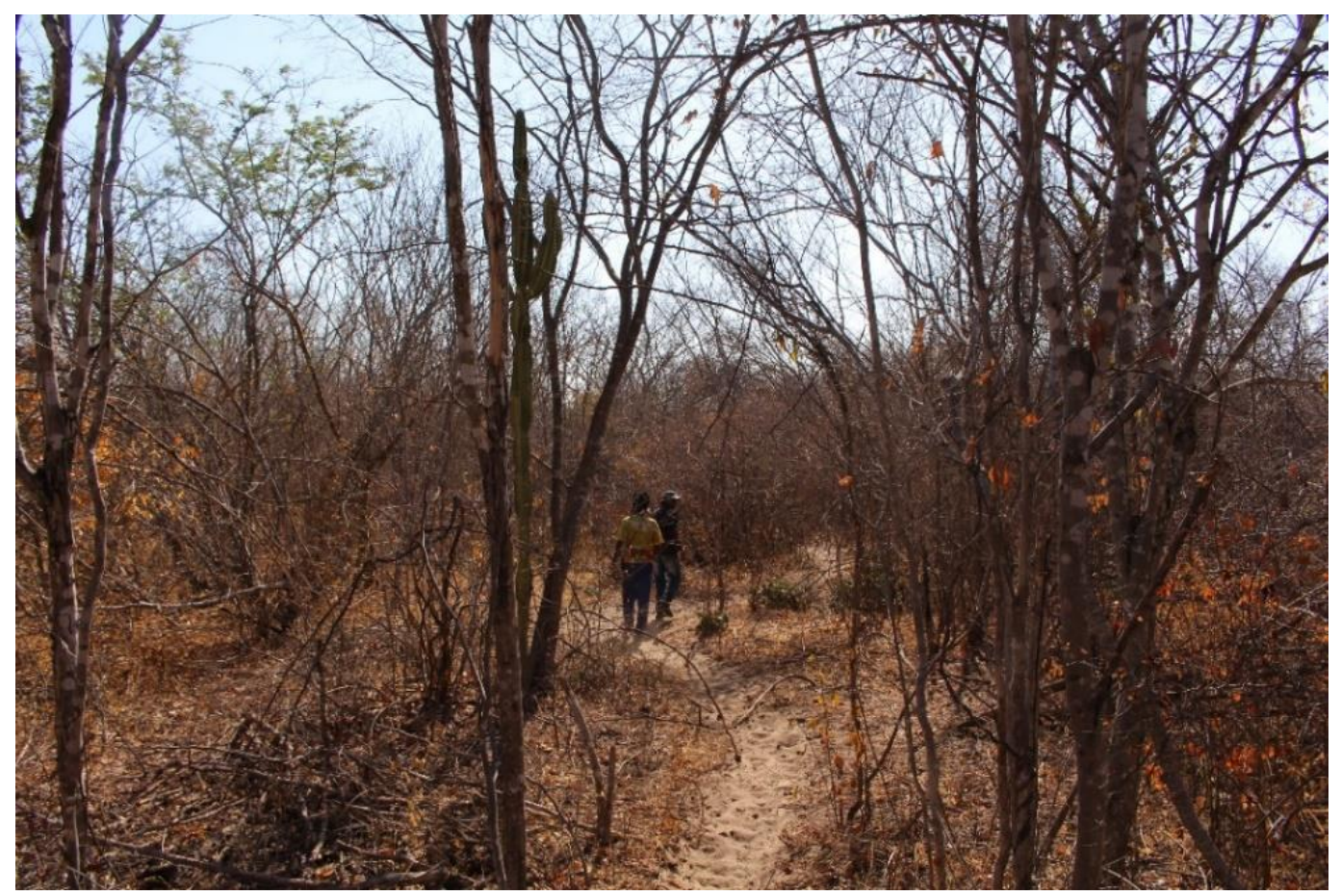

Figura 4 - Caatinga em Lagoa do Peixe - Fonte: Antonio Sales

A partir dessas informações levantadas em campo e com ajuda das análises de geoprocessamento, foi elaborado o mapa de uso tradicional e geomorfologia fluvial que aponta áreas de usos e suas características morfológicas na dinâmica fluvial do Rio São Francisco. (Figura 5) 


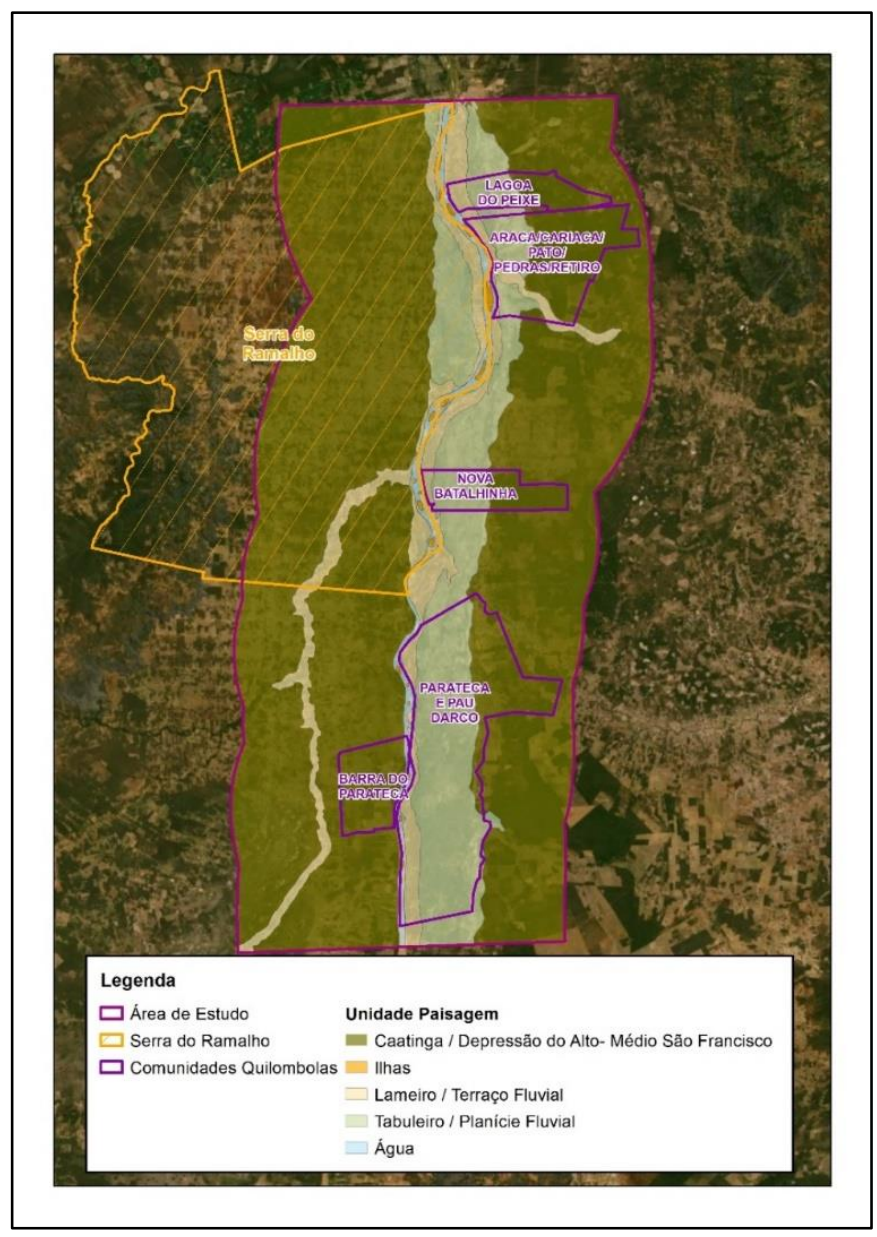

Figura 5 - Mapa de Uso Tradicional e Geomorfologia Fluvial - Fonte: IBGE ,2001

O estudo da conjuntura ambiental das comunidades quilombolas Lagoa do Peixe e Araçá/Cariacá indicou a importância da utilização do leito maior excepcional 2 como unidade de análise, não somente por sua variedade de usos, mas também por sua importância no ecossistema dada sua distinta interação rioplanície como aponta Rocha e Rocha (2011):

2 É ocupado quando ocorrem as maiores cheias, as chamadas enchentes. O que diferencia o leito maior do leito maior é que o primeiro é submerso a intervalos irregulares, ou seja, nem todos os anos, enquanto o segundo é ocupado anualmente de forma regular. (Guerra, 2008) 
A morfologia, os depósitos e as características hidrodinâmicas assumem grande importância na estrutura e função dos ecossistemas rio-planície de inundação. Como resultado, observa-se um alto grau de heterogeneidade espaçotemporal dos processos físicos, químicos e bióticos nesses ecossistemas, que promovem uma grande riqueza de espécies. Tal riqueza, por sua vez, também está relacionada diretamente à grande diversidade de formas (habitats) e ecótonos; e ainda, que a dinâmica fluvial originada pela inundação ao longo do tempo é responsável pelos diferentes estágios sucessionais dos ambientes aquáticos, transicionais e terrestres, relativos à própria evolução geomórfica do sistema fluvial.( ROCHA, 2011, p.65)

As peculiaridades deste ecossistema podem ser entendidas pelas dinâmicas do sistema rio-planície que podem se expor de variadas formas, apresentando uma conjunção interdependente entre as feições do modelado aquático e terrestre, que atuam diretamente na composição da diversidade de espécies e nas dinâmicas geomorfológicas no perfil longitudinal dos canais fluviais. Como afirma Rocha (2011):

O sistema rio-planície de inundação tem como uma de suas principais características um alto grau de dinamismo geomorfológico, determinado pelos processos de erosão e sedimentação. Como uma consequência desses processos, a paisagem é constantemente modificada, e diretamente interfere nos processos de sucessão ecológica (ESTEVES apud ROCHA, 2011, p.60).

Além da relevância dos estudos das planícies de inundação para a preservação desses peculiares ecossistemas, o entendimento dos impactos das atividades humana dinâmicas do sistema rio-planície, também contribui para compreensão do modo como a ação humana interfere nos processos fluviais. Sobretudo, com o desenvolvimento, nos últimos tempos, das técnicas de engenharia, as atividades humanas têm aumentado sua intervenção sobre os mais diversos tipos de canais fluviais, que visam o controle da vazão ou atenuar os efeitos de enchentes ou deposição de sedimentos. Tais atividades causam impactos diretos que alteram o perfil longitudinal, do rio padrão do canal a seção transversal, dentre outras coisas. (GUERRA, 1994)

Cunha aponta 
As mudanças fluviais indiretas que resultam das atividades humanas, realizadas fora das área dos canais, mas que modificam o comportamento da descarga e da carga sólida do rio. Tais atividades estendem-se para a bacia hidrográfica e estão ligadas ao uso da terra, com a remoção da vegetação, desmatamento, emprego de práticas agrícolas indevida, construção de prédios e urbanização. (GUERRA,1994, p.238)

A atividades margens do Rio São Francisco no trecho de Bom Jesus da Lapa, compõe uma interessante área de estudo, pois nesta região já identificadas as presenças de territórios 5 comunidades quilombolas diferentes oficializados pela Fundação Cultural Palmares (Lagoa do Peixe e Araçá/Cariacá, Lagoa das Piranhas, Mangal/ Barro Vermelho e Nova Batalhinha), assim como projeto público de irrigação Formoso. gerido pela Companhia de Desenvolvimento dos Vales do São Francisco e do Parnaíba (Codevasf), considerado o maior produtor de bananas do Brasil $^{3}$. Tais características já indicam a complexidade e a importância de um estudo do uso do solo ao longo do leito maior excepcional do Rio São Francisco.

Desta forma, os contrastes das paisagens da planície fluvial do São Francisco em Bom Jesus da Lapa emergem da atuação de diferentes formas de territorialização que agem sobre essa parcela do espaço geográfico. A presença da cultura tradicional quilombola e da agricultura de monocultura voltada para a exportação representam distintas formas de apreensão da natureza, tornando a paisagem uma resultante das dinâmicas locais e globais 


\section{6 - Fundamentação Teórico-Metodológica}

\section{1 - Paisagem cultural}

A entendimento das relações ambientais e sua dinâmica requer uma visão integrada dos fatos físicos e ecológico dos sistemas naturais e de suas interatividades com os agentes socioeconômicos e políticos. (SAUER, 1925; HAESBAERT, 2007) Dessa forma, a análises de paisagens superam os limites de uma disciplina específica, tendo um caráter totalizante de observação do fenômeno da morfologia da paisagem, e dessa forma a Ecologia de Paisagem também adquire um caráter holístico de exame.

A Ecologia da paisagem avança com a ecologia tradicional ao, além de compreender os estudos das inter-relações verticais entre fauna, flora e elementos físicos dentro de uma unidade espacial homogênea, também focaliza no relacionamento horizontal das unidades espaciais (RAVAN e ROY, 1995). Deste modo, a Ecologia da Paisagem concilia a abordagem horizontal do geógrafo, através da análise do relacionamento espacial do fenômeno natural, com a abordagem vertical de um ecologista, os estudos da paisagem criam assim uma interrelação comum entre duas ciências, a Geografia e a Ecologia.

O processo de evolução das paisagens guarda estreita relação com a origem da ciência geográfica, sobretudo a partir das contribuições de Humbolt para ciência. Os trabalhos deste autor fundamentaram os procedimentos metodológicos da Geografia, sua busca pelos a compreensão da diferenciação das paisagens, a partir da correlação dos fenômenos físicos e ecológicos, como se pode observa em Tableau Physique, (1807), e também associava as características das paisagens às ações humanas. Deste modo, o conceito de paisagem, por seu caráter holístico, foi apropriado pelos geógrafos com uma das principais categorias de análise.

Humbolt teve enorme papel na instrumentalização da observação empírica como instrumento das ciências tanto ambientais quantos sociais, tido como um dos ícones da ciência alemã. Alvez (2005) descreve a provável influência dos trabalhos de Humbolt nos trabalhos do antropólogo teuto-americano Franz Boas, fundador da 
Antropologia estadunidense ou americana. Franz Boas se destacou por implementar a abordagem historicista como método para a compreensão da evolução cultural dos povos. Diferentemente das linhas darwinistas colocadas em seu tempo. Uma das principais contribuições de Boas, frente aos evolucionistas, se tratava da inclusão das estruturas psicológicas e as influencias ambientais nos destinos das culturas.

O estudo das mudanças culturais de cada povo ao longo do tempo era um dos principais temas do início do século XX. A geografia não ficou fora do debate. Ainda que algumas teorias geográficas sobre a cultura tenham sido consideradas um tanto determinísticas, foram estes mesmos pensadores que abriram o caminho para a aproximação do fenômeno cultural com o fenômeno físico no contexto da paisagem. É dentro deste contexto que o geógrafo americano Carl Sauer se insere no debate sobre cultura, evolução e meio ambiente. Sauer baseou seus estudos nas singularidades dos modos de vida de cada sociedade e na historicidade como caminho para compreensão da diversidade cultural (PEDROSA, 2015)

Um dos importantes aportes teóricos de Sauer se dá por sua discussão sobre qual deveria ser abordagem geográfica da relação sociedade-natureza. Para Sauer, a cultura assumia importância geográfica na medida em que seus efeitos são observáveis na paisagem, em sua concepção de Geografia os elementos materiais da cultura mereciam o mesmo tipo de interesse para a evolução da ciência quanto as formas da paisagem cultural.

all geography is physical geography... not because of an environmental conditioning of the works of man, but because man. himself not directly the object of geographic investigation. has given physical expression to the area by habitations. workshops. markets, fields. lines of communication. Cultural geography is therefore concerned with those works of man that are inscribed into the earth's surface and give to it characteriatic expression (SAUER apud SOLOT 1986, p.509)

Dando ênfase na expressão material da cultura, Sauer voltou suas observações para a analises dos fenômenos espaciais, os considerando mais do que um agrupamento de processos isolados, mas sob uma perspectiva na qual a relação dos elementos são associados ou interdependentes. Dessa forma, Sauer tinha que a 
paisagem como o conceito no qual a Geografia se representa inteiramente (SAUER, 1925)

Os fatos da geografia são fatos de lugar; sua associação origina o conceito de paisagem. Do mesmo modo, os fatos da história são fatos do tempo; sua associação origina o conceito de pendo. Por definição, a paisagem tem uma identidade que é .baseada na constituição reconhecível, limites e relações genéricas com outras paisagens, que constituem um sistema geral. Sua estrutura e função são determinadas por formas integrantes e dependentes. A paisagem é considerada, por- tanto, em um certo sentido, como tendo uma qualidade orgânica. (SAUER, 1925, p.23)

A abordagem material da cultura de Sauer lançou foco ao espaço construído das sociedades, sobretudo na tecnologia empregada e nos recursos disponíveis na área de uso, e deste modo a paisagem, por integralizar os processos ambientais e antrópicos, se tornaram, em uma concepção, o cerne dos estudos geográficos. Assim, Sauer, a partir o seu enfoque nos processos materiais da paisagem, atentava para a função e estrutura dos elementos da paisagem e da disposição espacial das formas os relacionamentos entre elas, e sobretudo se atentando para a quantificação dos processos, dessa forma se tornando, além um dos pioneiros da Geografia Cultural, também, talvez, um dos percursores da Ecologia de Paisagem.

A descrição não é de uma cena individual, mas um somatório de características gerais. Referências a outros tipos de paisagem são introduzidas por -implicação. Relações de elementos da forma dentro da paisagem são também observados. Os aspectos selecionados são baseados no "conhecimento da situação real", e existe uma tentativa de se fazer uma síntese dos elementos da forma. Sua importância é uma questão de julgamento pessoal. Padrões objetivos podem ser substituídos por eles somente em parte, assim como pela representação quantitativa na forma de um mapa. (SAUER, 1925, 27)

\section{2 - Ecologia da Paisagem: holismo e métricas}

O termo Ecologia da Paisagem aparece na literatura da ciência ambiental por meio dos trabalhos do geógrafo alemão Carl Troll (1939), que pretendia criar 
um novo ramo de análise ambiental no qual geógrafos e ecologistas trabalhassem em conjunto com o objetivo de centralizar os estudos dos fundamentos da vida e da terra. $\mathrm{O}$ estudo da paisagem na concepção de Troll passava a ser o cerne dessa na ciência, tratando este conceito como entidade que integraliza todos processos espaciais e visuais, englobando a geosfera, biosfera e a noosfera. Os trabalhos de Troll foram uns dos principais disseminadores dos estudos da paisagem. (BERTRAND, 1968; ZONNEVELD, 1979)

A mobilização de Troll, acarretou em esforços de diversos acadêmicos pelo mundo BUNCE e JONGMAN,1993), sendo os mais notáveis os trabalhos de Tranley (1935), DYLIS (1964) e ZONNEVELD (1972). Ao longo do século XX, a Ecologia da Paisagem se assentou com uma disciplina voltada para o estudo da ecologia humana englobando todas as relações materiais, ambientais e culturais da sociedade, assim a conjuntura biofísica, produtividade primária, biodiversidade, resiliências das espécies, condição dos recursos dos solos e hídricos e ciclos de nutrientes.

A Ecologia de Paisagem, como disciplina, ou campo de estudo e pesquisa aplicados, smpre buscou integrar relações entre os fenômenos e processos da paisagem, sobretudo na análise holística dos padrões texturais da paisagem e seus processos de gênese (METZGER, 2001). A Ecologia da Paisagem passou a ser compreendida com a disciplina que teria como enfoque o estudo holístico da estrutura, função e alterações dos ecossistemas (LANG \& BLASCHKE, 2009), sendo tais características definidas como:

Estrutura - é o resultado da relação espacial entre distintos ambientes ou agentes presentes numa dada área, como está arranjando os elementos da paisagem (caracterizado pelo tamanho, forma e padrões dos ecossistemas) que rege a oferta energética, materiais e da biota.

Função - Interrelações entre os elementos da paisagem, representadas pelos fluxos de energia, físicos e de interconexão entre as espécies.

Mudança - dada pela perturbação na estrutura e na função do arranjo ambiental ao longo do tempo. 
As análises da Ecologia da Paisagem por seu caráter holísticos apresenta múltiplos níveis de interação entre os elementos de uma paisagem, assim variados escalas de observação de modelação de paisagem, evidenciando um dos principais problemas relativos aos estudos de análise de paisagem está no caráter arbitrário na definição das unidades de paisagens feita pelo observador (METZGER,2001). Neste contexto de determinação das unidades de paisagens, aponta que compreensão que o domínio territorial e o entendimento do saber etnoambiental das diferentes sociedades muitas vezes fica expresso na terminologia descritiva utilizadas pelas diferentes etnias que pode atuar como abordagem inicial para o entendimento das estruturas de paisagem.

A linguagem é um dos principais produtos culturais sendo elaborada por aqueles que vivem e observam ao longo do tempo os ciclos e dinâmicas ambientais de uma área e dessa forma os fenômenos e estruturas da paisagem também tem espaço garantido no vocabulário dos diferentes grupos. $\mathrm{O}$ apoio do conhecimento popular, na visão de Sauer (1925), pode ser um dos para a compreensão dos fenômenos das paisagens e suas associações de uso comunitário, e contribuindo para a redução do caráter arbitrário da determinação das unidades de paisagens. 
Os fatos de área sempre estiveram sob observação popular a tal ponto que uma nova terminologia é quase sempre desnecessária... as formas da paisagem tinham geralmente recebido nomes populares práticos e que a codificação poderia prosseguir partindo do falar popular, sem a criação de novos termos. Agindo amplamente desse modo, construímos uma lista de termos que está sendo enriquecida a partir de muitas áreas e muitas línguas. Muitos ainda estão aguardando a introdução na literatura geográfica. Esses termos se aplicam largamente às formas do solo, drenagem e formas climáticas tanto quanto se aplicam à superfície terrestre. O uso popular também deu nome a muitas associações vegetais e nos preparou ainda uma insuspeitável riqueza de termos das formas culturais. A terminologia popular é uma sanção aceitável do significado da forma, como é subentendida na sua adoção. Tais nomes podem ser aplicados a componentes de formas isoladas como clareira, um pequeno lago, löes. Ou podem ser associações de formas de magnitudes diferentes como alagado, estepe, piedmont. Ou podem ser nomes próprios para designar unidades da paisagem, como, por exemplo, os nomes regionais que são usa dos na maior parte da França. Essa nomenclatura popular é rica em significado genético, mas com avaliação corológica exata ela enfatiza não a partir da causa, mas de um somatório genético, isto é, a partir das semelhanças e contrastes de formas. (Sauer, 1925, p. 37)

As concepções de Sauer sobre as representações linguísticas das formas do território somam-se ao conceito de unidade de Paisagens, elementos da paisagem ou ecótopoos (land unit) originalmente elaborado por Christian e mais tarde revisitada por Zonneveld contribuem para entendimento contornos da paisagem. As Unidades de paisagens são tidas como compartimentos de paisagem, complexos parciais os quais atuam na estrutura da paisagem, ou seja, elementos da paisagem, como agrupamentos litológicos, feições fluviais ou categorias geomorfológicas.

Sobre a perspectiva das análises da Ecologia da paisagem, as divisões em unidades de paisagens e sua inerente variabilidade, apresentará uma série de diferentes conformações espaciais e que de acordo com suas características relativas a morfologia e distribuição dentro das estruturas das paisagens, que se interrelacionam em múltiplos níveis atribuindo, dessas formas, características funcionais aos elementos da paisagem. 
Paisagens apresentam determinadas funções que estão associadas a processos naturais elementares. Em adequação ao conjunto estrutural, a heterogeneidade apresenta-se também com base nas características funcionais de paisagens. Essas características funcionais podem ser agregadas nos quatro principais grupos das funções ecológicas, quais sejam: função de hábitat, função de proteção, função de regulagem, bem como funções de desenvolvimento. Funções são sempre direcionadas para uma finalidade e representam a dimensão do objetivo dos processos que ocorra em numa paisagem.

A ação do tempo é de fundamental importância para análise de paisagem, pois é a partir da observação do desenvolvimento e mudança da estrutura e função das unidades de paisagens por um determinado período possibilita significativos resultados. O histórico dos índices e métricas da paisagem apontam por meio de padrões, os arranjos e configuração da paisagem destacando os processos espaciais a partir de uma análise espacial-temporal.

\section{3 - Os Sistemas de Informações Geográficas e Sensoriamento Remoto}

Um dos passos mais relevantes na observação dos fenômenos da paisagem foi dado pelos lançamentos de satélites, que incorporaram uma nova perspectiva e um novo paradigma para as ciências ambientais. A captação de dados da resposta espectral da superfície terrestre feitas pela introdução do sensoriamento remoto se transformou rapidamente em importantes ferramentas de mapeamento, monitoramento e gestão das atividades humanas e ambientais (LAUER et al.,1997).

Os Sistemas de Informações Geográficas (SIG) podem ser considerados como as ferramentas mais importantes e holísticas para a análise e gestão da paisagem. (LANG \& BLASCHKE,2009 b)

Os SIGs, sobretudo o sensoriamento remoto, contribuíram para uma mais ágil e eficaz detecção dos objetos e sua consequente representação da realidade. A utilização do SIG e captar o arranjo espacial tanto quantitativamente, em termos de 
área e distribuição espacial, bem como qualitativo, destacando as características físicas, ambientais e sociais atribuídas aos objetos, destacando desta forma os mapeamentos de uso e cobertura da Terra. (IBGE,2013)

Segundo Aspinnall e Hill (2008), o objeto dos estudos de uso e cobertura da Terra pode ser definido como assunto interdisciplinar, que se concentra no material relacionado com esse uso e cobertura, suas mudanças no espaço e tempo, incluindo dimensões política, social, econômica, cultural, e ecológica dos processos que produzem esses padrões e mudanças de tomada de decisão, ambiental. A capacidade de cálculo computacional foi imensamente ampliada com o advento das nuvens de processamento facilitou a análise de grandes volumes de dados, assim elevando potencial das análises espaciais.

O desenvolvimento do programa Landsat, um satélite voltado exclusivamente para a observação dos fenômenos da geográficos pôde prover dados para estudos dos fenômenos de interface terra/mar, cobertura vegetal, áreas urbanas e agrícolas. As interpretações dos dados-obtidos pelo Landsat foram fundamentais para um outro nível de análise econômicas e de qualidade ambiental, revolucionando as técnicas de análises dos processos geográficos e das demais ciências naturais. (LAUERet al., 1997)

\section{7 - Materiais e Métodos}

A pesquisa se baseou na coleta e análise de dados espaciais, imagens do acervo Landsat disponíveis na plataforma Google Earth Engine e NASA, assim como em dados de campos, combinados com a história da paisagem por meio da descrição da trajetória das duas comunidades vazanteiras em foco. A principal plataforma utilizada para organização e análise dos dados espacialmente explícitos, shapefiles da bases digital do IBGE (2021), foi o ArcMap 10.5 e o Google Engine.

A representação cartográfica das complexas transições entre as diferentes fitofisionomias se coloca como um grande desafio devido a influência das atividades humanas. Em apoio a atividade de mapeamento da cobertura do solo foram concebidos os sistemas de processamento de imagens de sensoriamento 
remoto que podem assistir na qualificação da identificação e classificação automática desses alvos a partir das características do espectro eletromagnético (cores e tons) refletido ou emitido pelos objetos. No entanto os resultados nem sempre condizem com a realidade apresentada.

Nesse sentido, produtos elaborados que considerem a classificação do uso e cobertura com base na metodologia proposta podem servir como um importante subsídio ao planejamento ambiental, uma vez que podem representar o espaço com maior complexidade.

Assim, afim de entender a dinâmica das relações espaciais na área de estudo, e sua relação com as políticas públicas implementadas pelo estado na planície de inundação do Rio São Francisco, foram definidos marcos temporais de forma analisar os impactos de tais políticas na evolução da cobertura vegetal da área. Desse modo foram definidos os seguintes marcos:

1. 1972 - Início do Plano de Especial de Colonização da Serra do Ramalho. (Tq)

2. 1988 - Os direitos das comunidades remanescentes quilombolas são reconhecidos na Constituição. (T0)

3. 2006 - As comunidades quilombolas Aracá/Cariacá, Lagoa do Peixe e Nova Batalhinha tem seus territórios reconhecidos, porém ainda não titulados, pela Fundação Cultural Palmares. (T1)

4. 2021 - Marco de análise para conjuntura ambiental mais recente. (T2)

\section{1 - O Trabalho de campo}

Com a finalidade de contribuir na elaboração do Estudo do Componente Quilombola referente uma etapa do processo de licenciamento ambiental de uma usina fotovoltaica, em Bom Jesus da LapalBA, fui convidado a atuar na "parte ambiental" de um estudo normalmente elaborado por antropólogos. Cumprindo as 
devidas determinações legais concluiu-se que as comunidades quilombolas Lagoa do Peixe e Araçá/Cariacá seriam objeto da consultoria, desta forma, durante 15 dias, eu e minha companheira antropóloga, representando uma multinacional da consultoria ambiental, fizemos um diagnóstico socioambiental de tais comunidades.

O trabalho de campo durou 15 dias, dividido em 2 campanhas. A partir dele, e foi feito um caminhamento da área visando o reconhecimento do território das comunidades quilombolas Lagoa do Peixe e Araçá/Cariacá. Tal empreitada teve como produto dados da história ambiental das comunidades captados através de entrevistas aplicadas, a captação de pontos de GPS para identificação e delimitação das práticas nas comunidades quilombolas e agrovilas, além de fotografias dos diversos usos da área ao longo da planície de inundação.

\section{2 - Google Earth Engine}

Despontando como uma grande evolução o Google Earth Engine concentra numa mesma solução a aquisição de imagens e processamento em nuvem, tornando o processo extremante célere. A plataforma conta com o acervo de satélites como MODIS e Sentinel, e todo o acervo do programa Landsat e a capacidade de computacional dos servidores do Google. A partir de programação JavaScript, a plataforma também tem a capacidade de criar rotinas de mapeamento automático, além de conter uma grande variedade de modelo estatísticos, assim como de interpolação e classificação. 


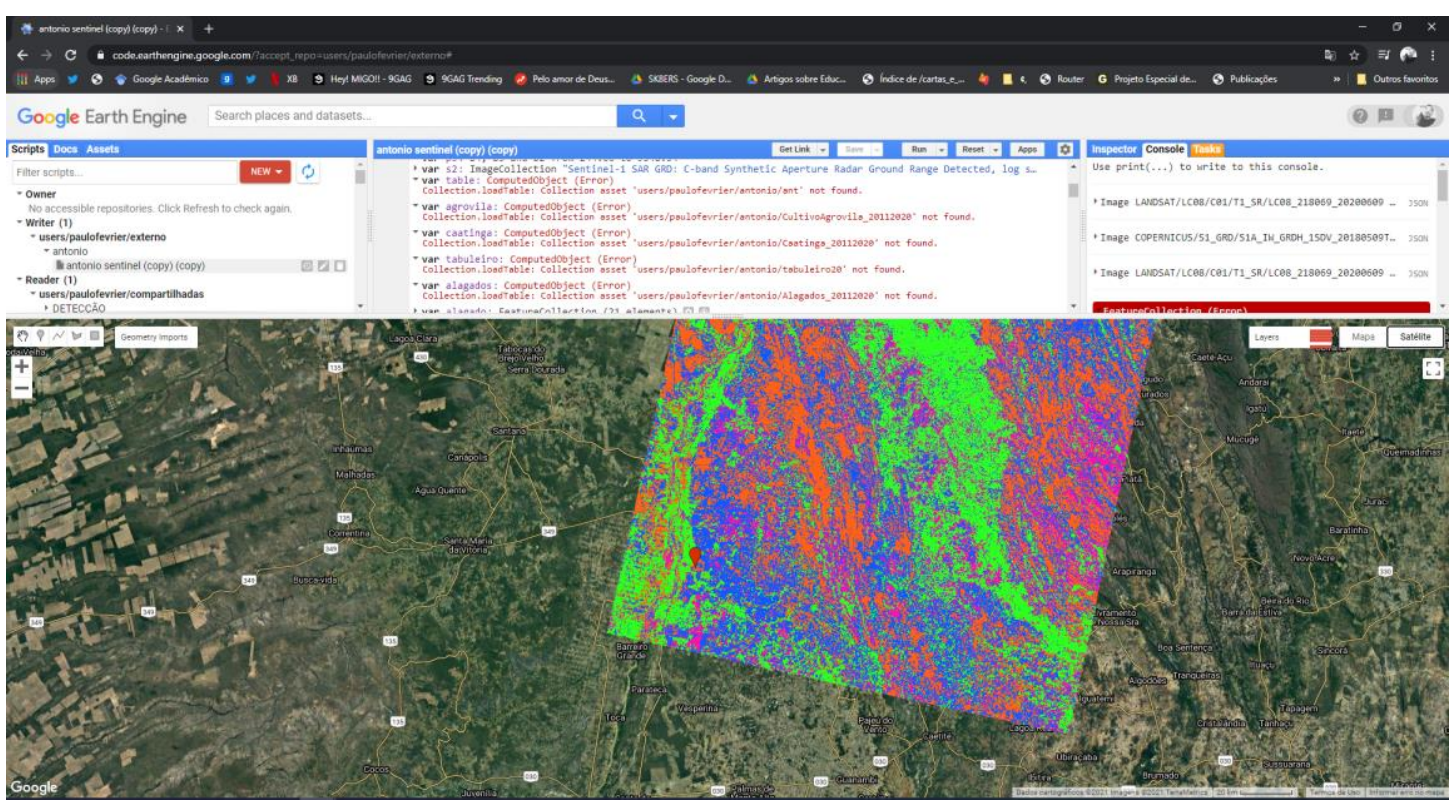

Figura 6 - Interface Google Earth Engine

Atualmente, as técnicas Classificação Baseada em Pixel, são um dos métodos mais antigo de análise espectral e se apresentam como importante ferramenta levando em consideração apenas as características espectrais de cada pixel. Considerando os objetivos com caráter temporal, a metodologia de classificação baseada em pixel por terem um rápido processamento e pela característica da cena a ser estudada, se apresenta com uma grande opção. O Google Earth Engine permite a inserção de novos parâmetros de avaliação para uma melhor identificação dos alvos e das nuances da composição da cobertura vegetal, possibilitando a melhor definição dos limites, e auxiliando na representação mais fiel do arranjo e das dinâmicas espaciais.

O Google Earth Engine por se tratar de uma ferramenta gratuita e que atribui grande agilidade a classificação dos usos do solo, e dessa forma foi utilizada como principal plataforma de aquisição e processamento de dados, conectando tecnologias do início da década de 70 como as imagens Landsat 1 a capacidade de processamento em nuvem do século XXI. 


\section{3 - Classes de Análises}

Nossos objetivos de estudo, os levantamentos de campo e as interpretações das diferentes texturas das imagens do acervo do Google Earth Pro induziram a escolha das seguintes classes de usos e coberturas:

- Caatinga Aberta

- Caatinga densa

- Agricultura

- Pastagem

- Urbano

- Água

- Solo Exposto

Deste modo foi utilizado um método híbrido de classificação nãosupervisionada/supervisionada das imagens Landsat, para alimentar a elaboração do script para processamento no Google Earth Engine. As entradas dos comandos em Javascript dependem da indicação de alguns parâmetros iniciais, como a seleção de imagens por atributos como data, cobertura de nuvem e correção atmosférica.

A definição de um marco base de análise do processo de evolução do uso, originado no início dos anos 1970, acarretou na necessidade de buscar recursos, um tanto ultrapassados para a realidade dos sensores espectrais colocado em órbitas nas últimas décadas, no entanto de grande valia para uma análise ambiental temporal de um processo. Deste modo, foi levantado no acervo das imagens LANDSAT -1 imagens da área de estudo referentes a Setembro de 1972, por se tratar de apenas 4 faixas de bandas espectrais e de uma resolução espacial de $80 \mathrm{~m}$, as métricas de quantitativo de uso passam a ter um caráter de uma referência generalizada, já que o comparativo com as atuais LANDSAT-8, com 7 faixas de banda espectral e resolução espacial de até $15 \mathrm{~m}$, torna-se muito prejudicada. 


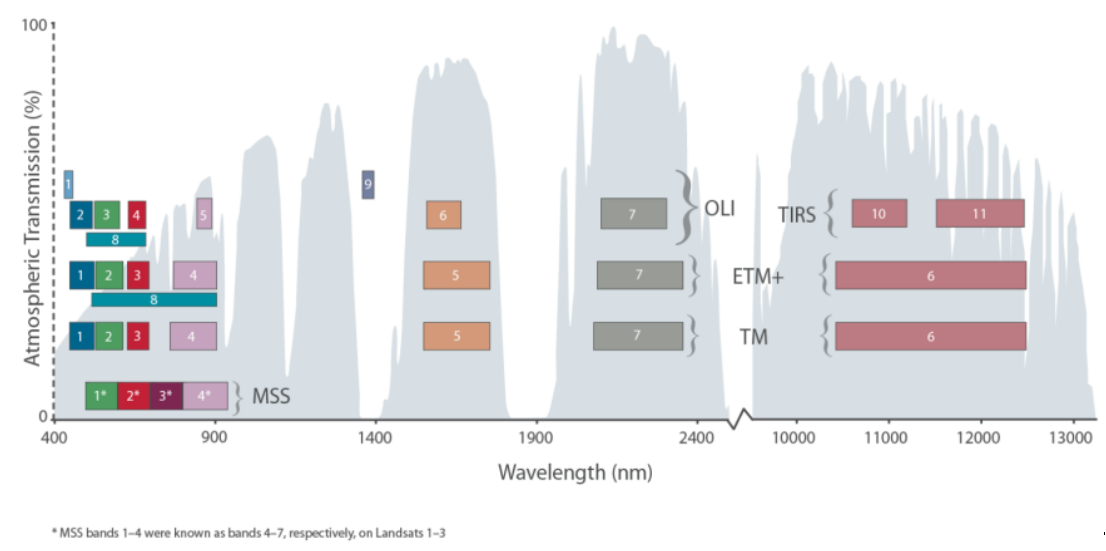

Figura 7- Sensores do programa Landsat e suas respectivas faixas de cobertura espectral

\section{4 - Cluster K-Means}

Em busca de uma parametrização das respostas espectrais presentes nas cenas, LANDSAT 1, mas sobretudo pelo mosaico de três imagens LANDSAT 8, necessário para cobrir toda a área de estudo, foi usado o método de classificação não-supervisionada Cluster K-Means, para a identificação dos conjuntos de respostas espectrais. A álgebra de mapa aplicada pelo método aplicado pode ser compreendida pela seguinte equação:

$$
J(V)=\sum_{i=1}^{c} \sum_{j=1}^{c_{i}}\left(\left\|x_{i}-v_{j}\right\|\right)^{2}
$$

Onde,

'\|xi - vj ||' é a distância euclidiana entre xi e vj.

'Ci' é o número de pontos de dados no $\mathrm{i}^{\mathrm{o}}$ cluster.

'C' é o número de centros de cluster.

As análises de resposta espectral na imagem LANDSAT-1 de 1972 primeiramente apontaram a impossibilidade de serem dispostas agrupamentos espectrais para além de 6 classes, sendo seu limite máximo de classificação 
espectral, apesar do limite tais classes tem uma abrasividade espacial condizentes com a trajetória de uso do solo da região. Deste modo, foi possível identificar que agrupamentos espectrais de referentes a água, pastagem, solo exposto e vegetação densa foram passíveis de uma rápida identificação. No entanto classes como área urbana, capoeira contam com uma reflectância muito próximas a outras classes e ainda terão de serem reclassificadas manualmente.

A aplicação de método Cluster K-Means nas cenas de 2021 LANDSAT-8 mostraram resultados também bastantes aderentes as nuances das respostas espectrais das imagens. Dentro do mesmo modelo de parametrização da aplicação do método na cena LANDSAT-1, os agrupamentos espectrais resultantes do apresentaram bastante coerência com as representações das imagens, sobretudo pelas delimitações das variações da vegetação que foram melhor definidas a partir da execução do método.

Porém um dos principais apontamentos dados pelos resultados da aplicação do método na cena LANDSAT-1 foi a certificação tendência de generalização, dada pelo limite de resolução do pixel, prejudicando a produção de métricas mais fieis do uso do solo. Já o resultado pra o mosaico de cena LANDSAT-8 indicou problemas referentes aos agrupamentos espectrais que representariam, classes como solo exposto e pastagem, pois apresentam um superdimensionamento das áreas.

No entanto considerando que o método Cluster K-Means é um processo de ajustes, os resultados servirão de importantes subsídios para a captura de amostras espectrais e parametrização referentes ao processamento da classificação supervisionada, pois fornecerá importantes insumos para o iniciar o processo de levantamento de 5000 pontos amostrais espectrais das classes definidas, para cada imagem necessária para a composição do mosaico da área de estudo. 


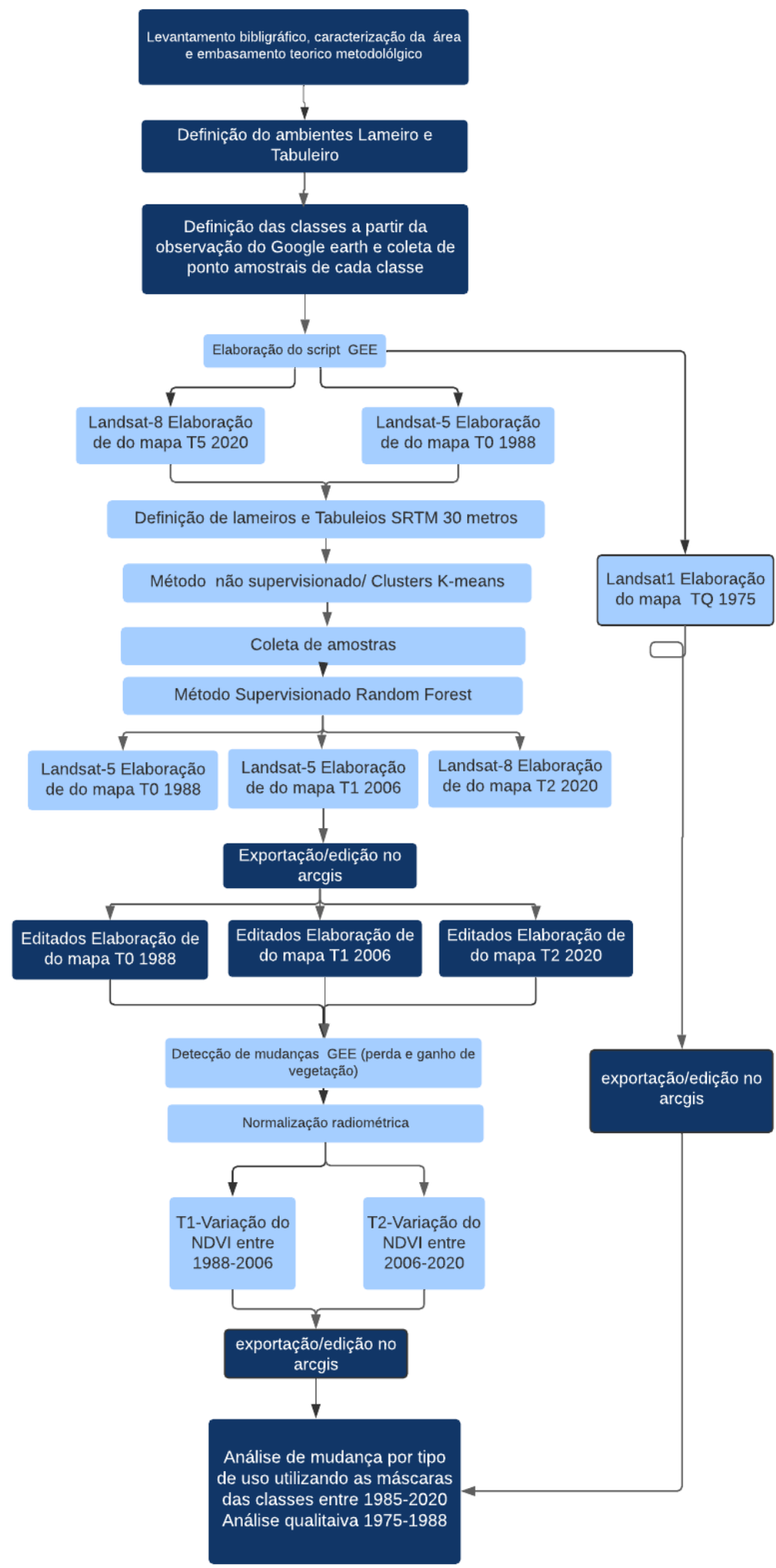

Figura 8 - Fluxograma metodológico - Fonte: Antonio Sales (2021) 


\section{5 - Random Forest}

E, de modo a refinar a classificação da nuvens de pontos de amostras coletadas, foi aplicado método classificador supervisionado "Random Forest", que usa de arvores de decisões que seguem os conceitos computacional de machine learning, se constituindo um método de aprendizagem de conjunto para classificação de dados amostrais que atua produzindo uma infinidade de árvores de decisão no momento do treinamento e produzindo as classes, que são definidas a partir da somas dos votos das árvores de decisão

O Random Forest, desenvolvido por Tim Ho em 1995, este classificador baseado em regressões lineares, ainda é amplamente utilizado e bastante consolidado no campo de agrupamento de dados. A premissa é que a combinação de classificadores do conjunto é muitas vezes mais precisa do que qualquer um do conjunto, evitando os conflitos entre os subconjuntos de recursos. (TIAN,2016)

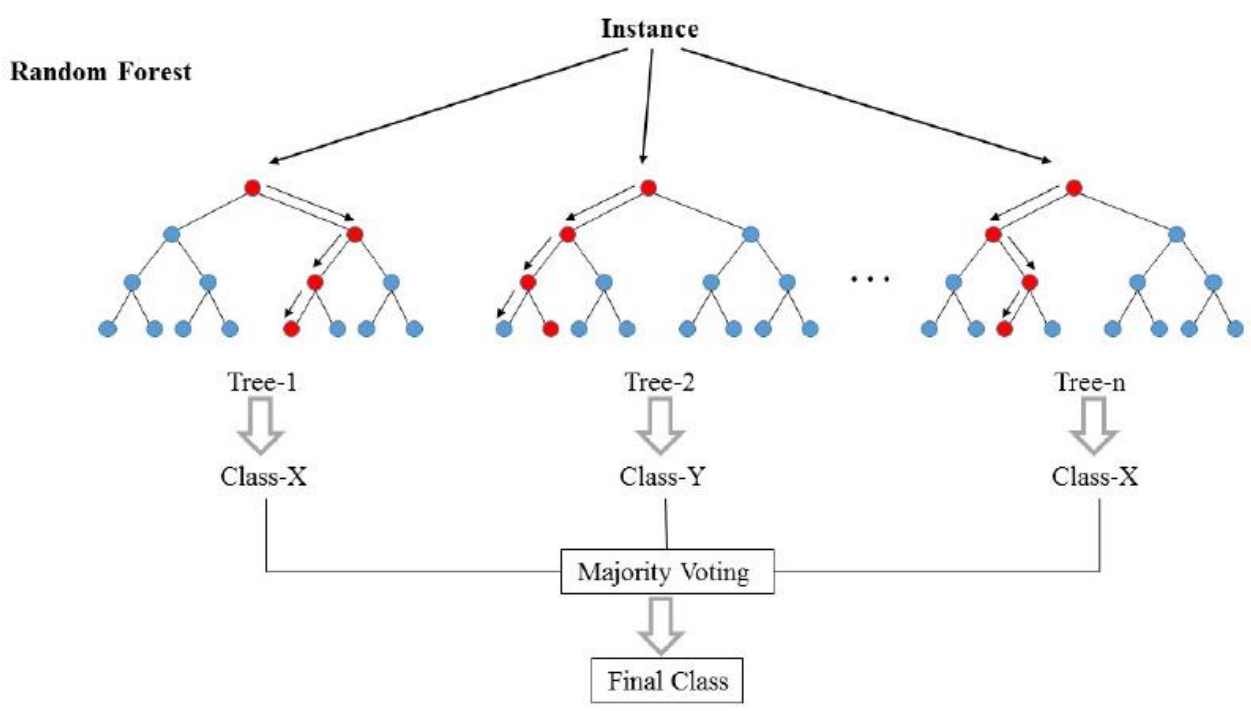

Figura 9 - Exemplo do método Random Forest

\section{6 - Mascara Geomorfológica}

A delimitação das unidades de paisagens a serem analisadas levou em conta as categorias geomorfológicas as quais estão submetidas no ciclo ambiental 
presentes na planície de inundação do Rio São Francisco e sua relação com a cultura vazanteira. Dessa forma, foi utilizado a base geomorfológica digital do IBGE 1:25000, na qual estão mapeados os domínios geomorfológicos de todo país em diversas escalas. $\mathrm{O}$ cruzamento das espaciais da base digital com o polígono da área de estudos com identificou as áreas com predominância de determinados processos geomorfológicos e respectivas unidades de paisagem

Tal delimitação visa entender a trajetória da dinâmica cobertura partir das pe área caracterizada pelo de recorrente processo de deposição de sedimentos e matéria orgânica, assim os seus correspondentes usos são insumos para compreender as permanências ou as mudanças das dinâmicas da planície de inundação.

Assim o cruzamento das cotas altimétricas e os usos levantados identificou as áreas relativas ao leito menor/ Alagados / Lameiros, a faixa entre 381m e 432m; leito maior excepcional/tabuleiro entre $432 \mathrm{~m}$ e $440 \mathrm{~m}$; e caatinga/limite leito maior a partir da cota $440 \mathrm{~m}$. Tais áreas por serem unidades de paisagens das práticas culturais vazanteira, a mais pretérita da área de estudo, serão o ponto focal para a compreensão da evolução do processo de mudança do uso do

A identificação das faixas altimétricas dos usos, ainda em processo de detalhamento, serve de base para a quantificação dos diferentes tipos de cobertura vegetal da área de estudo. Apesar das respostas espectrais da vegetação dos Alagados / Lameiros e Caatinga serem próximas, a fitofisionomia destas as áreas têm estruturas e funções diferentes. Dessa forma, foi aplicada uma máscara altimétrica para identificação dos domínios das paisagens, assim as classes altimétricas serão utilizadas como parâmetro de filtragem para as respostas espectrais da vegetação, adequando-as de acordo com seus nichos.

\section{7 - Detecção de Mudanças}

Dessa forma, segue-se para o processo de exportação e edição do resultado prévio da classificação no ArcGis, onde serão feitas as devidas correções de ruídos serão executadas nas áreas de usos mapeados, posteriormente tais classificações retornam ao GEE para serem detectados, para iniciar o processo de detecção de 
mudanças que se baseia em identificar e quantificar as mudanças temporais a partir de dados de períodos distintos (SINGH, 1989). O grau de mudança em diferentes períodos pode ser feito a partir da comparação de seu correspondente em outro momento. (NIEMEYER et al., ,2008)

A diferença entre os valores de pixel, como reflectância e radiância, é a análise mais comum de detecção de mudanças. Niyemeyer e Mussbaum 2006) demostraram que as classificações, podem ser utilizadas para quantificar pixel a pixel as alterações dos usos, a partir da elaboração de índices normalizados e segmentados. Para Kiel (2008), a detecção de mudanças obtidas por técnicas algébricas como subtração e razão de imagens entre as bandas originais e/ou transformadas, apresentam-se como sofisiticadas técnicas para identificação das áreas de mudanças.

\section{8 - Normalização Radiométrica}

Devido as diferentes condições ambientais e os diferentes sensores a partir do qual foram adquiridas as imagens em diferentes momentos se faz necessária a compatibilização dos níveis de cinza, de cada banda espectral de uma série temporal, dessa forma foi aplicada uma normalização radiométrica visando extrair os valores espectrais de objetos claros e escuros que tenham pouca variação entre as cenas. Esses valores serão calculados a regressão linear $(y=a x+b)$, onde uma das cenas é tida como referência $\mathrm{X}$, e as imagens as imagens a serem corridas $\mathrm{Y}$. (MALUF, 2015; PONZONI, 2012)

\section{9 - Índices Vegetação e Umidade}

Desse modo, passasse ao processo de criação de índices de vegetação e umidade para as imagens os cálculos das repostas espectrais NDVI (Índice de Diferença Normalizada de Vegetação), que mede a absorção da luz solar na região do vermelho relacionada a captação da vegetação por meio da clorofila para a 
fotossíntese, e NDWI (Diferença Normalizada de Água), este gerado por de combinações das bandas espectrais do verde e do infravermelho próximo, proporcionando uma melhor percepção das áreas mais úmidas e demais corpos d'água.

\section{NDVI $=($ Infravermelho - Vermelho $) /($ Infravermelho + Vermelho $)$}

Equação 1 - Índice de Diferença Normalizada de Vegetação

$N D W I=($ Verde - Infravermelho $) /($ Verde + Infravermelho $)$

Equação 2 - Índice de Diferença Normalizada de Água

\subsection{0 - Classificação de Imagens}

A análise de mudança por tipo de usos e dará pela utilização de máscaras entre as classificações do marcos temporais reconhecimento constitucional dos direitos quilombolas em 1988 sendo T0, o marco incial, e o T1 sendo o ano 2006 a partir reconhecimentos dos territórios quilombolas pela Fundação Cultural Palmares. Já o T2 se dá pelo Marco de análise para conjuntura ambiental mais recente 2021. Após o processo de detecção de mudanças no GEE, os dados serão exportados mais uma vez para o ArcGis pra a definitiva quantificação das transformações mapeadas nas classificações. Como os dados da Landsat 1 tem seu processamento limitado e devido as características da imagem, os dados do produzidos por essa cena serão frutos de uma análise somente qualitativa da evolução do uso do solo, sendo o Tq considerando os cenários de 1975 e 1988.

Dessa forma, a atingir os objetivos propostos e compreender a curva de evolução do cenário ambiental do trecho da planície de inundação estudada, serão utilizadas técnicas a exemplo da transformação de bandas, como NDVI que, a partir das formas geradas pela classificação de 1988 (T0), serão produzidas comparações bitemporais cenário a cenário. Para a detecção de mudanças de 1988 a 2021

As mudanças temporais, suas condições e evolução da paisagem são possíveis de serem aferidas, a partir da utilização de métricas da paisagem, extraída de análises de área, área-núcleos, borda, vizinhança, diversidade, retalhamento e 
heterogeneidade. Essas análises da evolução da estrutura e mudança da paisagem irão proporcionar uma análise qualitativa dos processos que imperam na gênese do espaço da área estudada. Lang e Klug (2006) apontam que esse método é capaz e trazer luz sobre as relações de causalidade entre os processos presentes baseandose nos arranjos espaciais perceptíveis

\section{8 - Resultados}

Antes da apresentação dos dados processados cabe o reconhecimento dos créditos à referida operação da plataforma Google Earth Engine ao geógrafo Me. Paulo Frevrier exerce suas competências como analista ambiental do INEA-RJ a mais de uma década.

Os índices de cobertura vegetal são um dos principais indicadores de salubridades das paisagens, os serviços ambientais prestados pelos fragmentos de vegetação nativa. A análise temporal da distribuição e das características fitofisionômicas dos fragmentos vegetais, sobretudo em ambientes de intensidades climáticas como a caatinga, é um dos principais elementos para um diagnóstico das relação sociedade-ambiente. As análises quantitativas colheram importantes dados para uma comparação das diferentes dinâmicas da paisagem em diferentes cenários.

Primeiramente, em um contexto geral, sem a descriminação das unidades de paisagem e aplicação da metodologia para o cenário dos limites da Área de Estudo, das Comunidades Quilombolas/Vazanteiras do munícipio de Serra de Ramalho, mostrou uma tendência geral de mudança do arranjo da cobertura vegetal. Tais mudança são latentes, sobretudo a transição de "Caatinga Densa", sensivelmente presente no cenário 1972 (Tq), infelizmente não-passível de extração de métricas devido a limitação das imagens do satélite Landsat-1, sobretudo as métricas relativas à agricultura.

No entanto, os dados do Landsat-1 puderam demonstrar que a área haviam alguns pontos de fragmentação ao longo da área de estudos, sobretudo na porção Sudoeste do buffer de $20 \mathrm{Km}$ onde a análise apresentou a presença de vegetação menos densa que poderia ser ao menos caracterizada caatinga aberta ou pastagem, 
há outras manchas nesta mesma condição espalhadas por toda uma área de matriz de caatinga fechada. Em Serra do Ramalho, é possível notar a presença de grandes fragmentos de caatinga densa/Pastagem, sobretudo nas áreas dos tabuleiros e no interior da unidade de paisagem e no setor Norte da unidade Caatinga presente em seu território. O cenário nas comunidades quilombolas apresenta uma maior variedade de fitofisionomia presentes em seus territórios, assim como no restante do buffer de $20 \mathrm{Km}$, os maiores pontos de fragmentação se apresentam na faixa das Tabuleiros e Lameiros, apontando para uma cultura de ocupação das margens do Rio São Francisco sendo o principal elemento da paisagem, conforme esperado considerando o desenvolvimento socioeconômico da década de 1970.

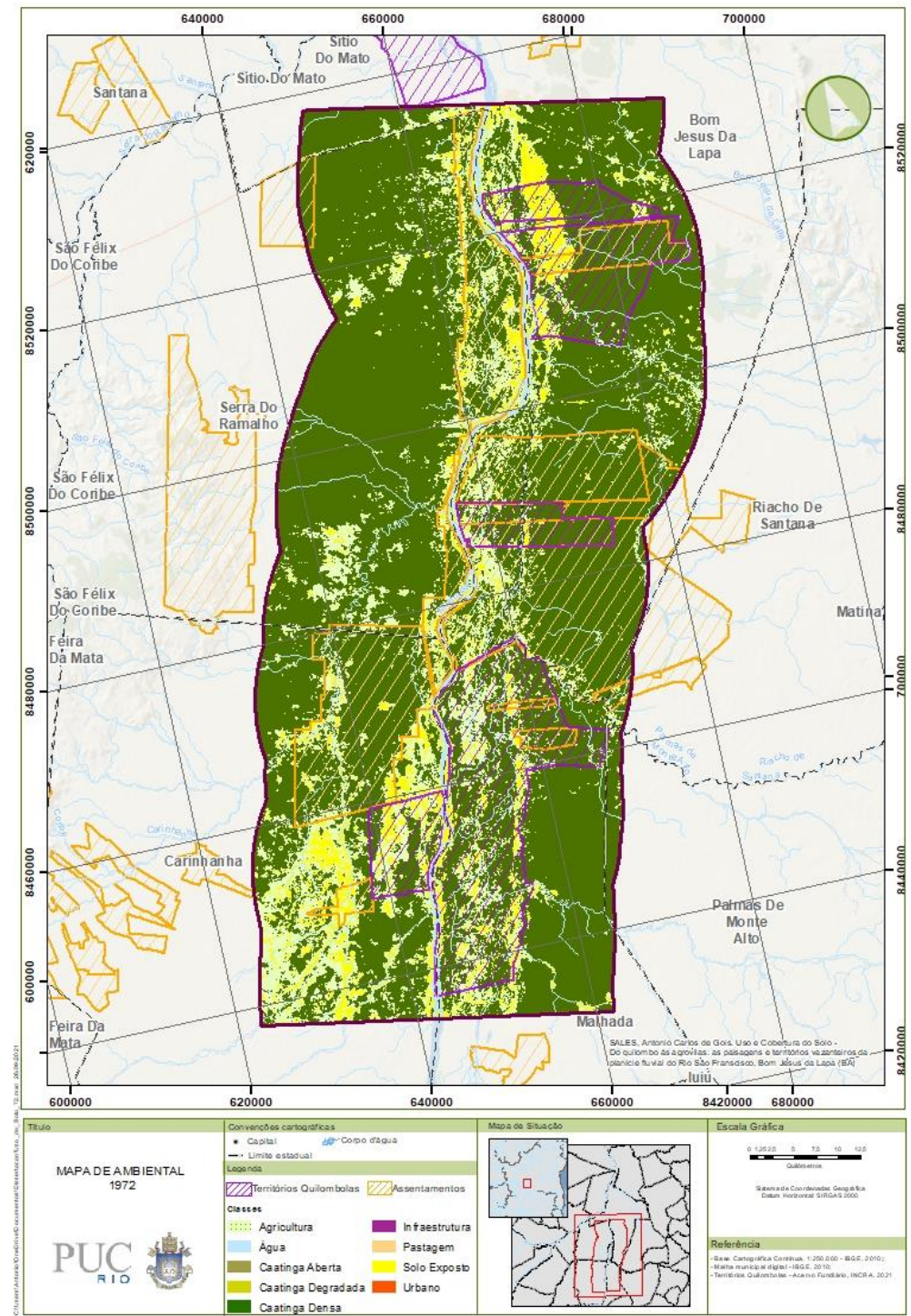

Figura 10- Mapa de Cobertura Vegetal - 1972 
A evolução da ocupação humana na área de estudo impactou diretamente na distribuição da cobertura vegetal, havia a presença predominante de $62,53 \%$ de “Caatinga Densa” em toda área de estudo, em 1988 (T0), em 2006 (T1) área ocupada por "Caatinga Densa" havia despencado para 25,42\% e atualmente 2021 (T2) se estende por apenas 15,56\% da região. Enquanto os valores de "Pastagem" tiveram uma transição de $17,71 \%$ no cenário de 1988 para 35,25\% da área total em 2021. O comportamento da "Caatinga Aberta" também mostrou considerável flutuação ao longo tempo, em 1988 a área de estudo contava com a presença de apenas 18,82\% da área total, passando para 33,58\% em 2006 e alcançado o nível de 44,10\% (Mapa X - Evolução da Cobertura Vegetal da Área de Estudo).

Outros índices de métricas da paisagem, o número de patches (NP), densidade de patches (DP), e o índice Largest Patch Index (LPI) são indicam da fragmentação de uma determinada classe de uma área. Assim, é interessante atentar para as métricas do cenário de 1988 (T0), onde a classe a "Caatinga Aberta se apresentou mais fragmentada, com 15.0923 NP, índices de DP 3,42 patches/100 ha e apenas 2,24 \% de LPI, foi já a classe "Pastagem", contava com 14.892 P e 3,37 patches/100 ha e 1,7 \% de LPI, destacando o papel de coesão da "Caatinga Densa" com $32,9 \%$ de LPI, o maior valor alcançado por uma classe no contexto de análise da área de estudo.

A evolução das métricas da "Pastagem" indicaram uma rápida evolução entres o período de 1988 e 2006, mostrando uma evolução do índice LPI para tal classe, enquanto no cenário T0 o a contava com um índice de 1,7\% da paisagem, no cenário T1 sobe para $19,92 \%$, um salto de $17,5 \%$ da paisagem, e atingindo o pico de 22,78\% em 2021 (T2). 

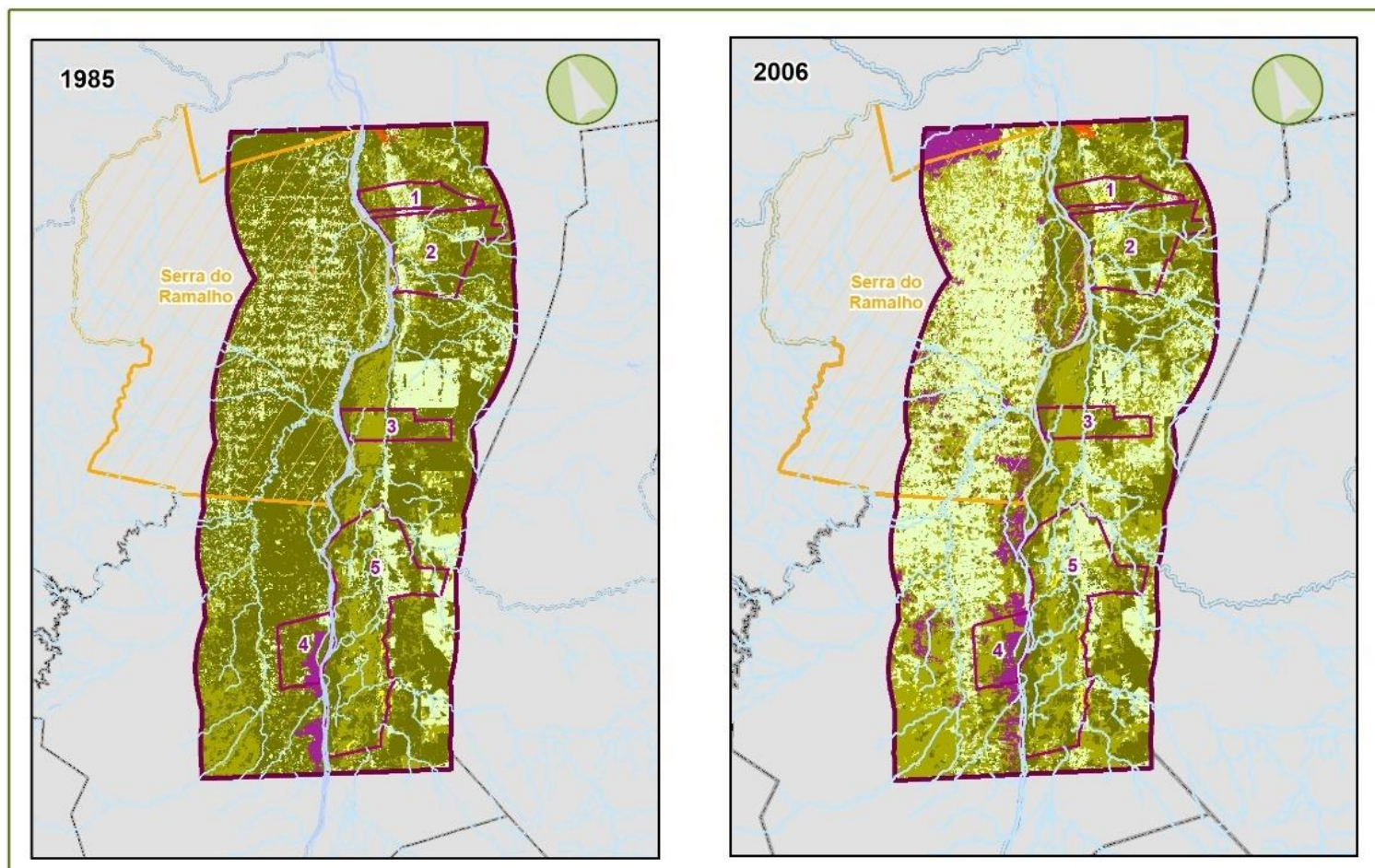

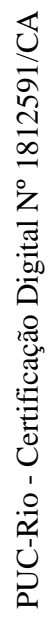
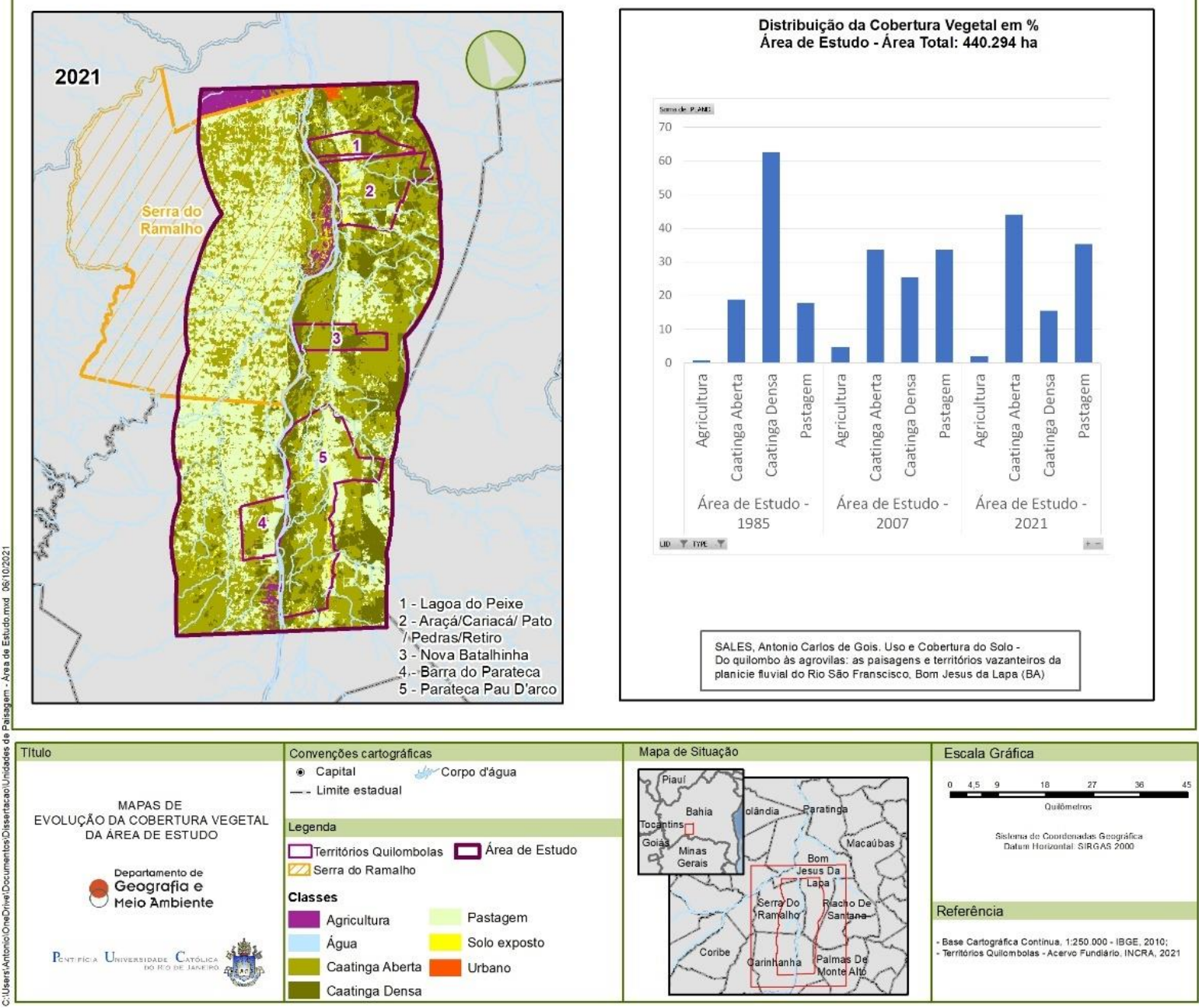
Figura 11- Mapa de evolução de cobertura vegetal da área de estudo

Em paralelo se deram a evolução do arranjo espacial das comunidades quilombolas, assim com o Projeto Especial de Colonização Serra do Ramalho, a distribuição de cobertura vegetal em seus respectivos territórios se mostrou tendências em comuns porém com intensidades dispares. Ambos territórios apresentam um processo de constante substituição de "Caatinga Densa" por "Caatinga Aberta" e "Pastagem"

No cenário 1988 (T0), o assentamento contava com 70,5\% de seus limites cobertos por "Caatinga Densa", e 20,1\% de "Pastagem", no presente cenário de 2021 (T2) a presença de "Caat-(d)" representava somente 3,8\% da cobertura vegetal da área do projeto de assentamento da ditadura. Os índices NP e DP, 2865 patches e 2,3 patches/100 ha, respectivamente, no cenário (T0) apresentavam uma enorme densidade de "Caat-(d)", como pode ser verificado no índice LPI, onde o maior fragmento encontrado correspondia pode 68,8\% (87.479 ha) de toda área, já em 2021 o maior pacote florestal de "Caat-(d)" representa apenas 1,2\% (4.790 ha).

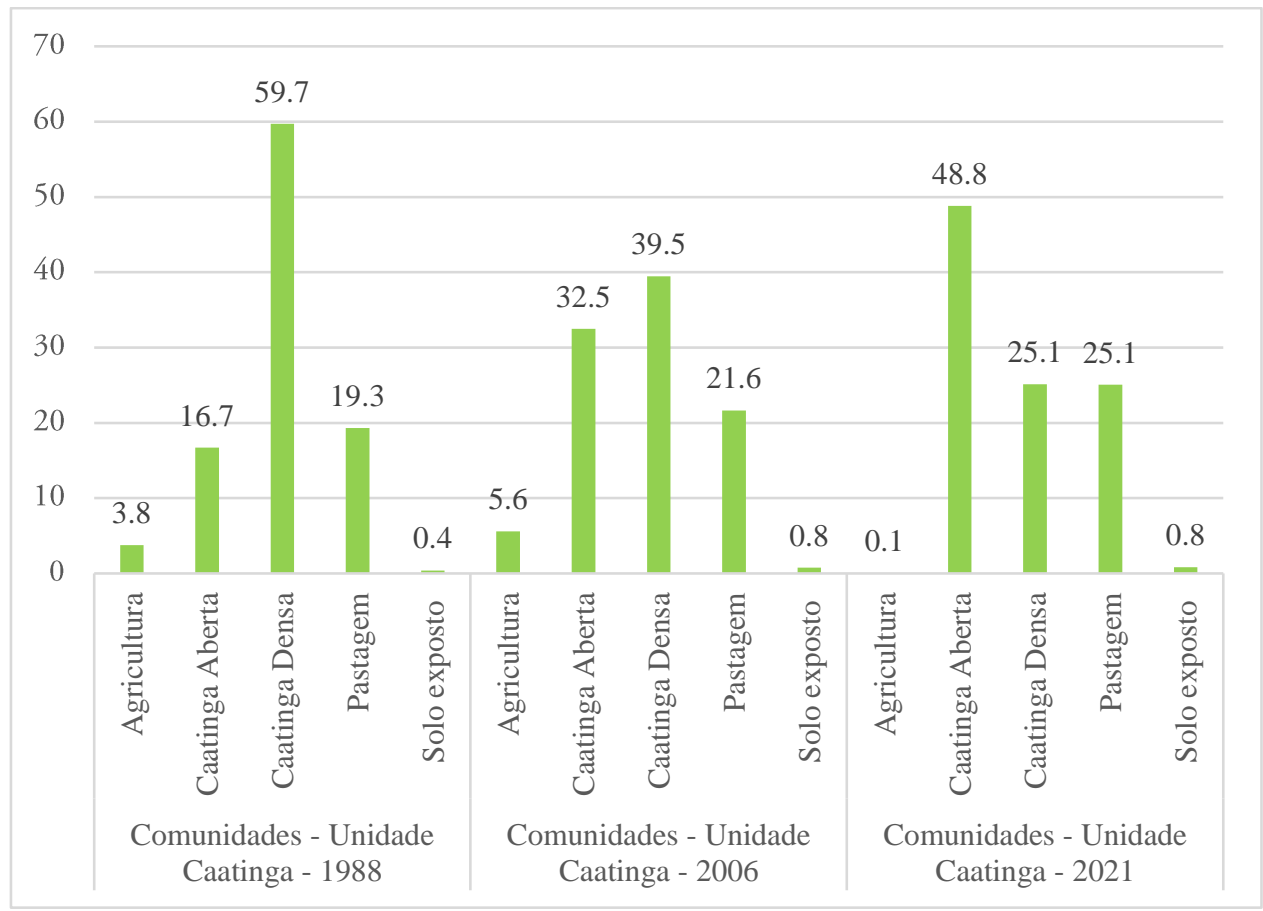

Figura 12 - Gráfico da evolução distribuição de cobertura vegetal em Serra do Ramalho 
A ocupação quilombola/vazanteira apresentou um ritmo de trocas de cobertura vegetal essencialmente lento comparado ao restante da área de estudo e de Serra do Ramalho. Enquanto nos outros recortes espaciais há índices que apontam para polarização da distribuição da cobertura vegetal em duas classes, Caatinga Densa e Pastagem, mas métricas das paisagens das Comunidades Quilombolas/vazanteiras indicam uma distribuição da cobertura vegetal mais diversa tanto ao longo do tempo, quanto espacialmente.

As análises indicaram que em 1988 as áreas dos territórios das comunidades tradicionais contavam com 50,7 \% de cobertura vegetal Caat-(d), e o maior fragmento desta classe correspondia a apenas 5,9\% do total das áreas dos territórios, segundo o índice LPI, os menores índices em comparação a área de estudo e a Serra do Ramalho no cenário (T0). As métricas das paisagens dos territórios quilombolas indicaram a presença relevante de Caatinga Aberta "Caat-(a)", também em T(0) onde já se presentava com $28,5 \%$ da área dos territórios e um densidade de patches de $3,14 \%$ patches/100 ha e maior índice LPI com 11,5\%. As análises indicaram que as mudanças na paisagem quilombola/vazanteira centraram-se na substituição da cobertura vegetal de Caat-(d) pra Caat-(a), pois a distribuição de "Pastagem" manteve-se estável ao longo do tempo, correspondendo à 16,9\% em T(0), passando para $19,5 \%$ em $\mathrm{T}(1)$ e $22,7 \%$ em $\mathrm{T}(2)$. 


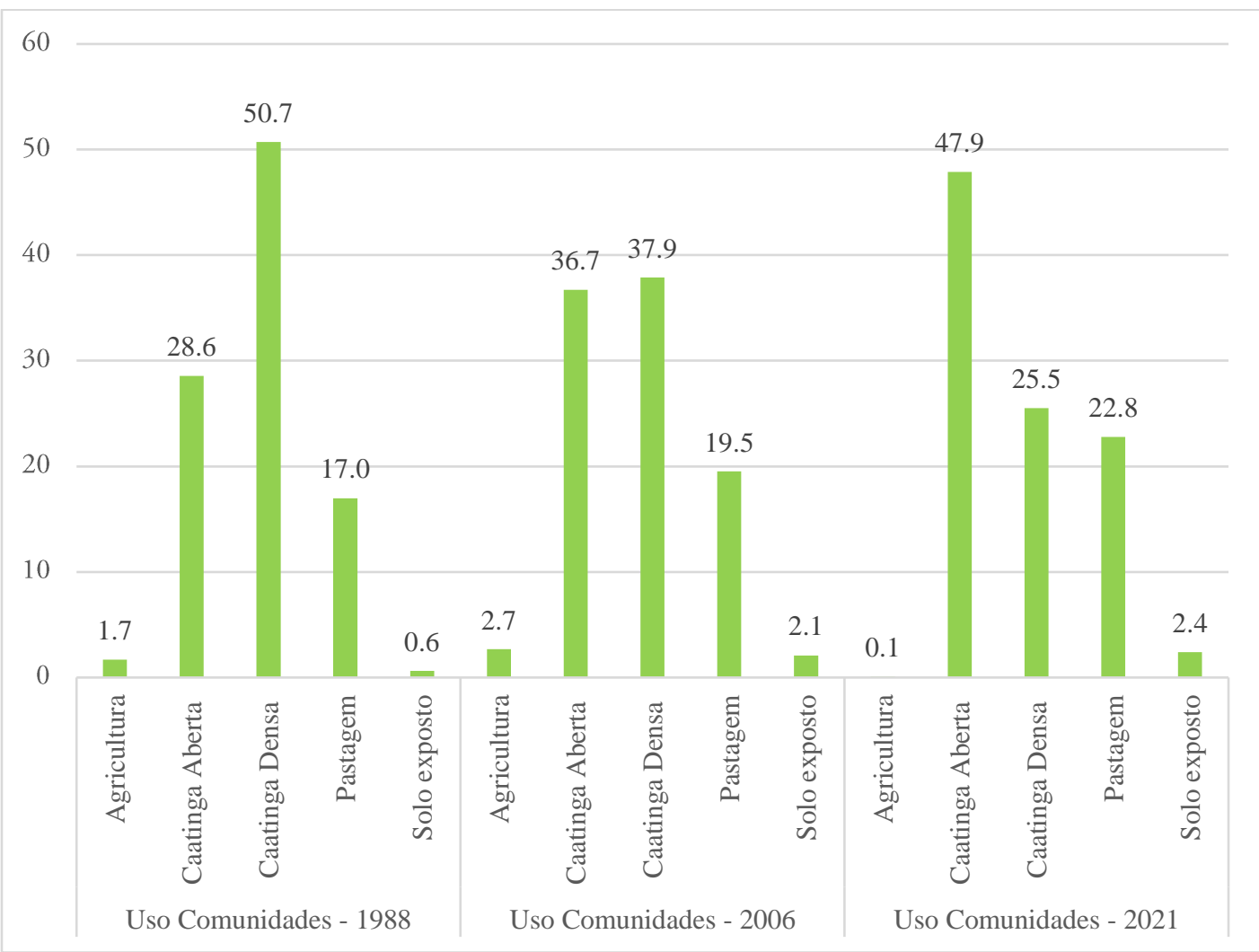

Figura 13 - Gráfico da evolução distribuição de cobertura vegetal nas Comunidades Quilombolas

Dessa forma, as métricas das paisagens indicaram que os arranjos espaciais inseridos no contexto de seus respectivos recortes apresentaram um estruturas e mudanças essencialmente diferentes que colaboram de formas diferente para o contexto ambiental da área de estudo. A análise detecção de mudanças apenas considera as áreas onde houve avanço ou retrocesso de área florestada independente de categoria, não há diferenciação entre caatinga densa ou aberta nos dados relativos a esses índices. 


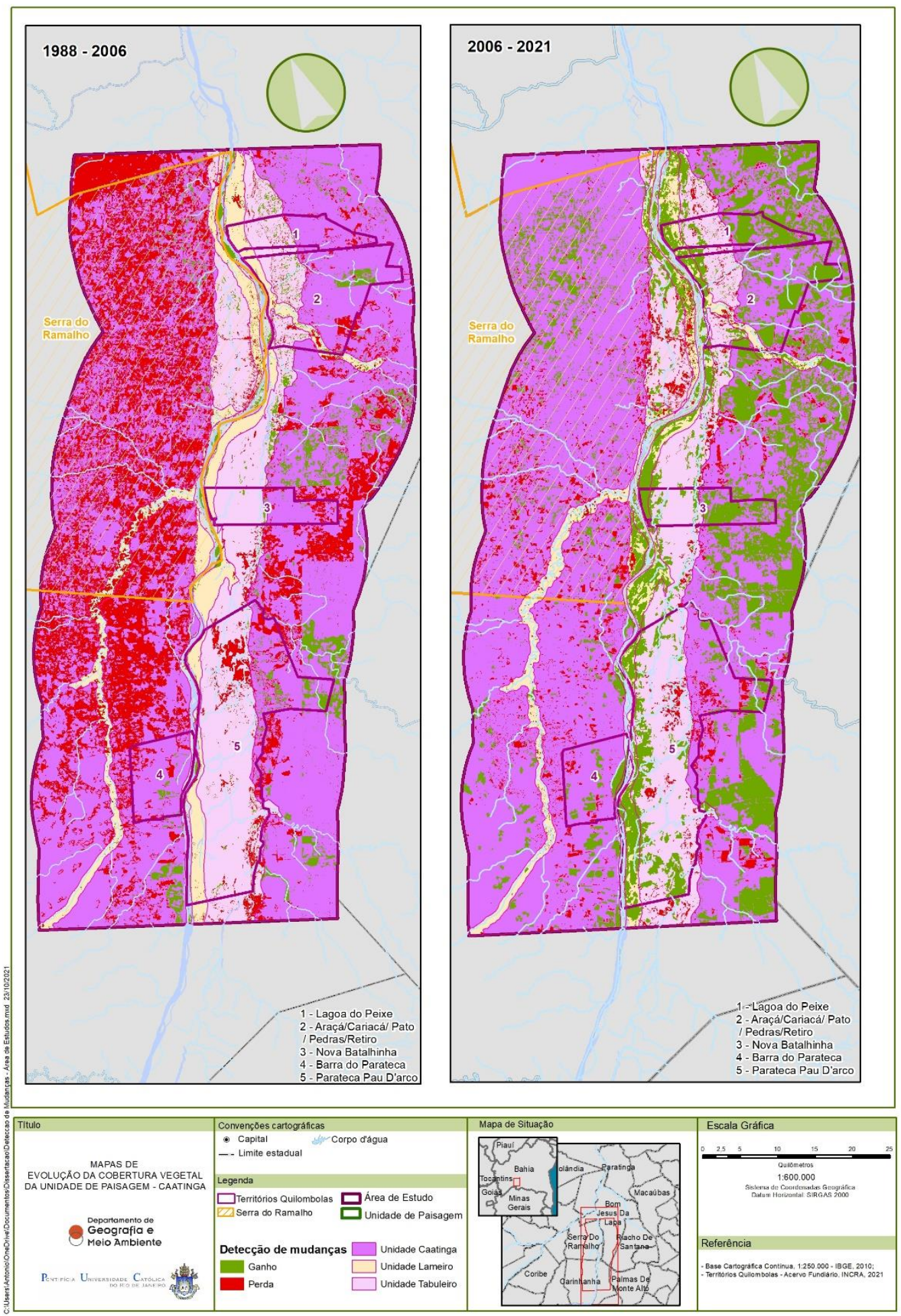

Figura 14 - Gráfico da evolução de ganhos e perdas de áreas florestadas área de estudo, comunidades quilombolas e assentamento Serra do Ramalho 
Em termos comparativos, a análise de perda e ganho pode identificar Tais análises apontaram que o recorte temporal abrangido pelo período entre 1985 e 2007 implicou em uma forte tendencia de desmatamento por toda área de estudo tendo um índice de redução de $20,4 \%$ de sua área de cobertura vegetal, enquanto no período entre 2007 e 2021 os dados indicam um direcionamento ao avanço das áreas de matas com o um saldo positivo de $16,1 \%$ de cobertura vegetal na área do buffer de $20 \mathrm{Km}$.

Das perspectivas dos outros dois pontos focais, as comunidades quilombolas e o Assentamento da Serra do Ramalho, as métricas apontaram caminhos completamente opostos. Apesar da tendencia de desmatamento entre 1985 e 2007, a diferença entre os dois tipos de ocupação é massiva, enquanto as comunidades quilombolas tiveram uma perda de $5 \%$ de cobertura de vegetação de caatinga em relação ao seu território, a área do assentamento teve um índice de perda de 38,6\% de área floresta seu território no mesmo período.

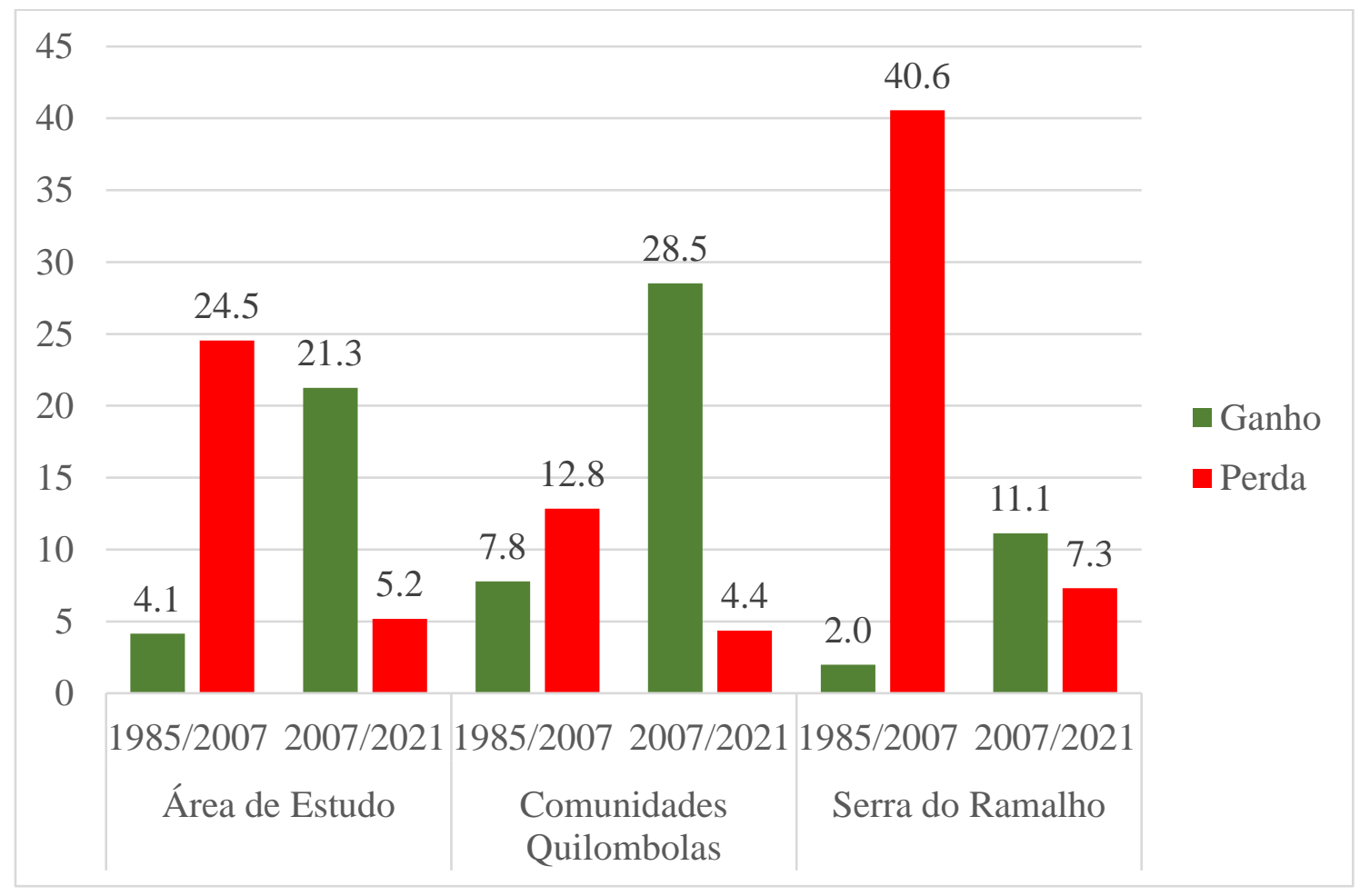

Figura 15 - Gráfico da evolução de ganhos e perdas de áreas florestadas área de estudo, comunidades quilombolas e assentamento Serra do Ramalho 
A análise identificou o período entre 2007 e 2021 como um momento de resiliência da caatinga em todo área de estudo, apesar de não indicar o aumento qualitativo das áreas de matas, devido ao predomínio da caatinga aberta em todos os recortes, a vegetação de caatinga apresentou um grande índice de recuperação, sobretudo nos territórios das comunidades quilombolas registrando um aumento de $24,1 \%$ de sua área de cobertura vegetal, enquanto Serra do Ramalho apresentou um índice de somente $3,8 \%$ de recuperação

\begin{tabular}{|c|c|c|c|c|c|c|}
\hline Usos - Área de E & studo, Comunida & les e Serra do & Ramalho & & & \\
\hline Categoria & Classe & Área (ha) & \begin{tabular}{|l|} 
Dristibuição \\
$(\%)$
\end{tabular} & $\begin{array}{l}\text { Número de } \\
\text { Patches (NP) }\end{array}$ & $\begin{array}{l}\text { Densidade } \\
\text { Patches (DP) }\end{array}$ & LPI \\
\hline \multirow{8}{*}{$\begin{array}{l}\text { Uso - Área de } \\
\text { Estudo - } 1988\end{array}$} & Caatinga Aberta & 82950,39 & 18,82 & 15092 & 3,4241 & 2,249 \\
\hline & Pastagem & 77364,63 & 17,5527 & 14892 & 3,3787 & 1,7078 \\
\hline & Caatinga Densa & 266934,51 & 60,5628 & 11326 & 2,5697 & 32,9897 \\
\hline & Caatinga Densa & 8698,23 & 1,9735 & 407 & 0,0923 & 1,8443 \\
\hline & Urbano & 513,72 & 0,1166 & 78 & 0,0177 & 0,078 \\
\hline & Água & 55,44 & 0,0126 & 59 & 0,0134 & 0,0021 \\
\hline & Pastagem & 706,86 & 0,1604 & 9 & 0,002 & 0,0497 \\
\hline & Agricultura & 3532,68 & 0,8015 & 6 & 0,0014 & 0,4085 \\
\hline \multirow{7}{*}{$\begin{array}{l}\text { Uso - Área de } \\
\text { Estudo - } 2006\end{array}$} & Caatinga Densa & 111961,89 & 25,425 & 12572 & 2,8549 & 1,7505 \\
\hline & Caatinga Aberta & 147873,96 & 33,5802 & 10786 & 2,4494 & 6,4594 \\
\hline & Pastagem & 147943,98 & 33,5961 & 6298 & 1,4302 & 19,9218 \\
\hline & Agricultura & 20827,98 & 4,7297 & 2678 & 0,6081 & 1,3717 \\
\hline & Solo exposto & 4060,26 & 0,922 & 397 & 0,0902 & 0,0349 \\
\hline & Água & 6985,35 & 1,5863 & 215 & 0,0488 & 1,4376 \\
\hline & Urbano & 707,76 & 0,1607 & 4 & 0,0009 & 0,1607 \\
\hline \multirow{8}{*}{$\begin{array}{l}\text { Uso - Área de } \\
\text { Estudo - } 2021\end{array}$} & Caatinga Aberta & 194167,8 & 44,1022 & 4258 & 0,9671 & 19,4725 \\
\hline & Caatinga Densa & 68514,93 & 15,5621 & 1927 & 0,4377 & 1,0552 \\
\hline & Pastagem & 155012,31 & 35,2086 & 1474 & 0,3348 & 22,7874 \\
\hline & Solo exposto & 4536,18 & 1,0303 & 267 & 0,0606 & 0,0385 \\
\hline & Água & 7733,79 & 1,7566 & 161 & 0,0366 & 1,5385 \\
\hline & Agricultura & 9329,04 & 2,1189 & 101 & 0,0229 & 1,1797 \\
\hline & Pastagem & 202,95 & 0,0461 & 16 & 0,0036 & 0,0137 \\
\hline & Urbano & 771,12 & 0,1751 & 1 & 0,0002 & 0,1751 \\
\hline \multirow{3}{*}{$\begin{array}{c}\text { Uso } \\
\text { Comunidades - } \\
1988\end{array}$} & Caatinga Densa & 42013,35 & 50,7268 & 2840 & 3,429 & 5,9839 \\
\hline & Caatinga Aberta & 23662,08 & 28,5695 & 2603 & 3,1429 & 11,5493 \\
\hline & Pastagem & 14067,27 & 16,9848 & 1898 & 2,2916 & 4,8618 \\
\hline
\end{tabular}




\begin{tabular}{|c|c|c|c|c|c|c|}
\hline & Água & 1154,7 & 1,3942 & 93 & 0,1123 & 1,1251 \\
\hline & Solo exposto & 531,54 & 0,6418 & 8 & 0,0097 & 0,2094 \\
\hline & Agricultura & 1393,83 & 1,6829 & 1 & 0,0012 & 1,6829 \\
\hline \multirow{6}{*}{$\begin{array}{c}\text { Uso } \\
\text { Comunidades - } \\
2006\end{array}$} & Caatinga Densa & 31375,89 & 37,8846 & 2570 & 3,1031 & 5,3456 \\
\hline & Caatinga Aberta & 30421,08 & 36,7317 & 1779 & 2,148 & 11,8595 \\
\hline & Pastagem & 16159,05 & 19,5111 & 1379 & 1,6651 & 7,4048 \\
\hline & Solo exposto & 1740,24 & 2,1012 & 178 & 0,2149 & 0,1724 \\
\hline & Água & 907,02 & 1,0952 & 96 & 0,1159 & 0,612 \\
\hline & Agricultura & 2216,34 & 2,6761 & 48 & 0,058 & 2,4716 \\
\hline \multirow{6}{*}{$\begin{array}{c}\text { Uso } \\
\text { Comunidades - } \\
2021\end{array}$} & Caatinga Aberta & 39660,21 & 47,8875 & 707 & 0,8537 & 15,8274 \\
\hline & Caatinga Densa & 21138,93 & 25,5241 & 389 & 0,4697 & 5,2509 \\
\hline & Pastagem & 18882,36 & 22,7994 & 328 & 0,396 & 9,3743 \\
\hline & Solo exposto & 2004,57 & 2,4204 & 104 & 0,1256 & 0,19 \\
\hline & Água & 1047,6 & 1,2649 & 90 & 0,1087 & 0,6622 \\
\hline & Agricultura & 85,95 & 0,1038 & 8 & 0,0097 & 0,0385 \\
\hline \multirow{5}{*}{$\begin{array}{c}\text { Uso Serra } \\
\text { Ramalho - } 1988\end{array}$} & Pastagem & 24984,09 & 20,1385 & 6133 & 4,9435 & 2,0932 \\
\hline & Caatinga Aberta & 8832,06 & 7,1191 & 5267 & 4,2455 & 0,3129 \\
\hline & Caatinga Densa & 87479,01 & 70,5129 & 2865 & 2,3093 & 68,8095 \\
\hline & Água & 2716,2 & 2,1894 & 146 & 0,1177 & 0,8002 \\
\hline & Urbano & 49,68 & 0,04 & 1 & 0,0008 & 0,04 \\
\hline \multirow{6}{*}{$\begin{array}{c}\text { Uso Serra } \\
\text { Ramalho - } 2006\end{array}$} & Caatinga Aberta & 29548,89 & 23,8273 & 4612 & 3,719 & 1,0722 \\
\hline & Caatinga Densa & 18852,93 & 15,2024 & 4285 & 3,4553 & 3,6149 \\
\hline & Agricultura & 7235,1 & 5,8342 & 2184 & 1,7611 & 1,2605 \\
\hline & Pastagem & 65382,66 & 52,7226 & 1620 & 1,3063 & 51,2188 \\
\hline & Solo exposto & 774,54 & 0,6246 & 96 & 0,0774 & 0,0681 \\
\hline & Água & 2218,5 & 1,7889 & 53 & 0,0427 & 1,7108 \\
\hline \multirow{6}{*}{$\begin{array}{c}\text { Uso Serra } \\
\text { Ramalho - } 2021\end{array}$} & Caatinga Aberta & 43527,24 & 35,1078 & 1802 & 1,4534 & 8,4229 \\
\hline & Caatinga Densa & 4790,25 & 3,8637 & 304 & 0,2452 & 1,2866 \\
\hline & Pastagem & 69442,65 & 56,0104 & 246 & 0,1984 & 52,8666 \\
\hline & Solo exposto & 951,21 & 0,7672 & 72 & 0,0581 & 0,0976 \\
\hline & Agricultura & 2850,12 & 2,2988 & 59 & 0,0476 & 1,4669 \\
\hline & Água & 2420,19 & 1,9521 & 49 & 0,0395 & 1,8204 \\
\hline
\end{tabular}

Quadro 1 - Métricas da paisagem das áreas de estudo, comunidades quilombolas e assentamento Serra do Ramalho

\section{1 - Unidade de Paisagem}

A cultura tradicional quilombola/vazanteira e sua relação de uso associada aos ciclos do Rio São Francisco orientaram a análises de métricas das paisagens 
para o entendimento da evolução da cobertura vegetal desses compartimentos da paisagem ao longo do tempo. O cruzamento da área de estudo e a base digital de geomorfologia do IBGE indicou a correlação das categorias geomorfológicas e as unidades de paisagens quilomboa/vazanteira, e os percentuais de distribuição de cada domínio da paisagem. (Quadro - 2)

\begin{tabular}{|l|r|r|}
\hline $\begin{array}{l}\text { Unidades Geomorfológica / } \\
\text { Paisagem Vazanteira }\end{array}$ & Área em ha & Distrbuição (\%) \\
\hline $\begin{array}{l}\text { Caatinga / Depressão do Alto- } \\
\text { Médio São Francisco }\end{array}$ & 330.361 & 75,03 \\
\hline Tabuleiro/ Terraço Fluvial & 66.289 & 15,06 \\
\hline Lameiro/Planície Fluvial & 33.405 & 7,59 \\
\hline Ilhas & 1.169 & 0,27 \\
\hline Água & 9.069 & 2,06 \\
\hline Total & 440.293 & 100,00 \\
\hline
\end{tabular}

Quadro 2 - Distribuição das unidades de paisagem na área de estudo

A unidade de paisagem quilombola/vazanteira Caatinga e sua correspondente geomorfológica a "Depressão do Alto- Médio São Francisco" representaram mais do que $75 \%$ de toda área de estudo, ao passo que as áreas de Tabuleiros e Lameiros correspondem a $15 \%$ e $7,5 \%$ respectivamente. Tais áreas além de estarem associadas ao usos tradicional da cultura vazanteira também contribuem pra serviços ecossistêmicos específicos, e de tal forma a evolução de suas estruturas devem ser foco de análises específicas.

\subsection{1 - A Unidade Caatinga}

A Depressão do Alto Médio-São Francisco tem como característica de pediplano com relevo monótono, suave-ondulado, predominando os solos arenosos e de baixa fertilidade (IBGE,2021). A ausência de grandes obstáculos naturais 
propicia uma facilidade de ocupação antrópica deste domínio, tal processo é refletido nas análises dos dados a geral. A diferença de uso dessa unidade de paisagem, sobretudo nos casos das comunidades quilombolas e Serra do Ramalho.

A despeito da variedade de cobertura vegetal presente em todo complexo paisagístico da unidade de caatinga, a análise da composição da cobertura vegetal apresentou resultados próximos aos apresentados no contexto geral dos recortes. A unidade de caatinga apresentava em 1988, índices de cobertura vegetal onde $65,59 \%$ da área desta unidade de paisagem era representada por cobertura de caatinga densa, as áreas de caatinga ainda contavam com 19,01\% de pastagens, e $14,08 \%$ de caatinga aberta. 
64

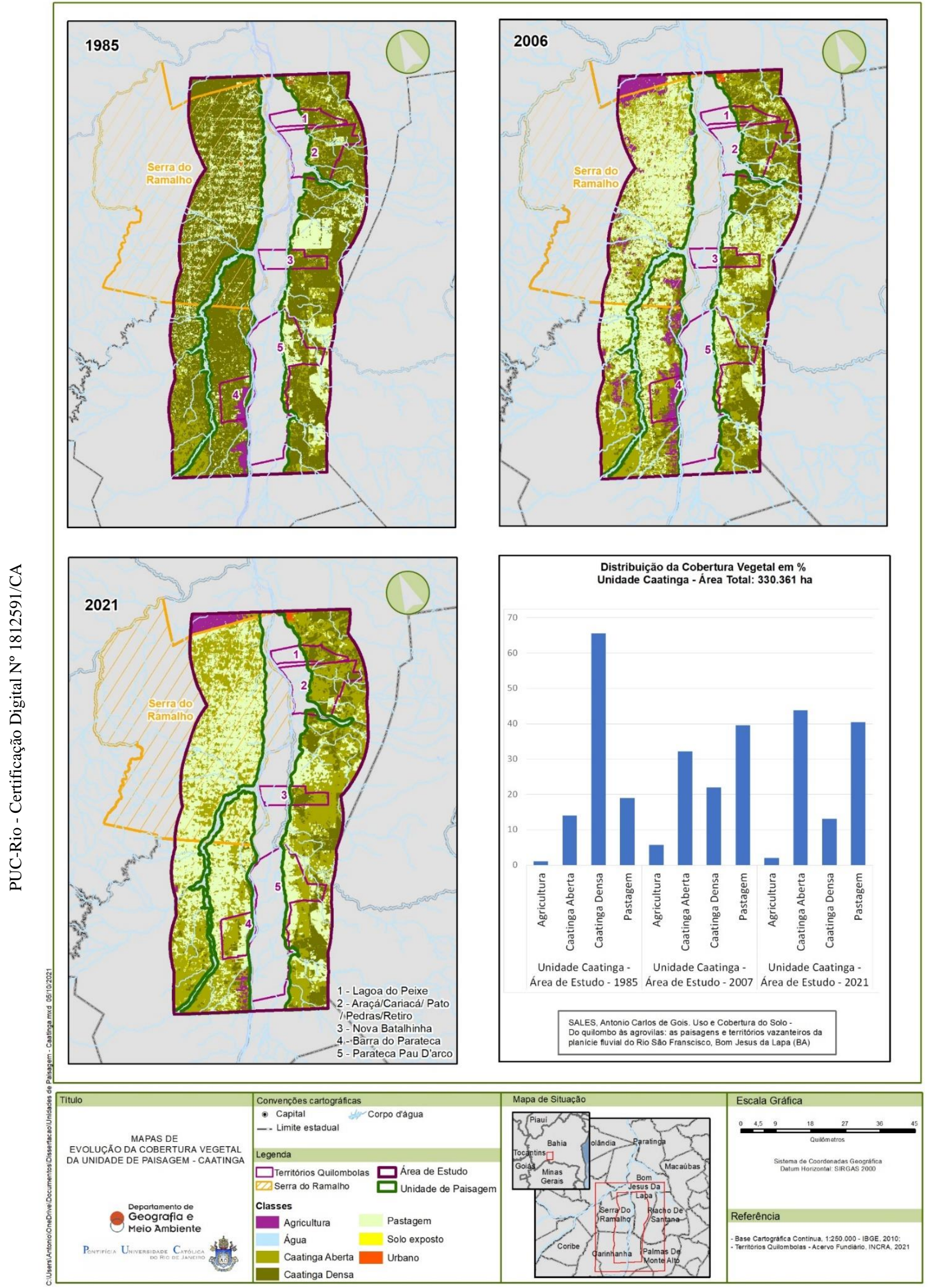

Figura 16 - Mapa de evolução de cobertura vegetal da unidade Caatinga 
Ainda em 1988 (T0), as métricas relativas a números, densidade e tamanho de fragmentos indicavam um forte domínio da cobertura de caatinga densa. No cenário T0, a classe caatinga densa apresentava 7148 patches em toda área da unidade de paisagem caatinga, atingindo um índice de densidade de patches 2,16 patches/100 ha e seu maior fragmento representava $26,21 \%$ desta unidade de paisagem em todo a área de estudo.

Como dito, a trajetória da unidade de paisagem caatinga por compor $75 \%$ do território seguiu as tendencia geral do buffer de $20 \mathrm{~km}$. No âmbito geral, a unidade de caatinga apresentou métricas com variação em torno de $2 \%$ nos valores apresentados no cenário de toda a área de estudo. Uma das principais mudanças na distribuição da cobertura vegetal em relação ao cenário da área de estudos se dá na unidade de caatinga de Serra do Ramalho que ao longo do tempo praticamente irradicou os fragmentos de caatinga densa de seu território passando de 72,7\% de cobertura para apenas $0,29 \%$ de toda área dessa unidade de paisagem.

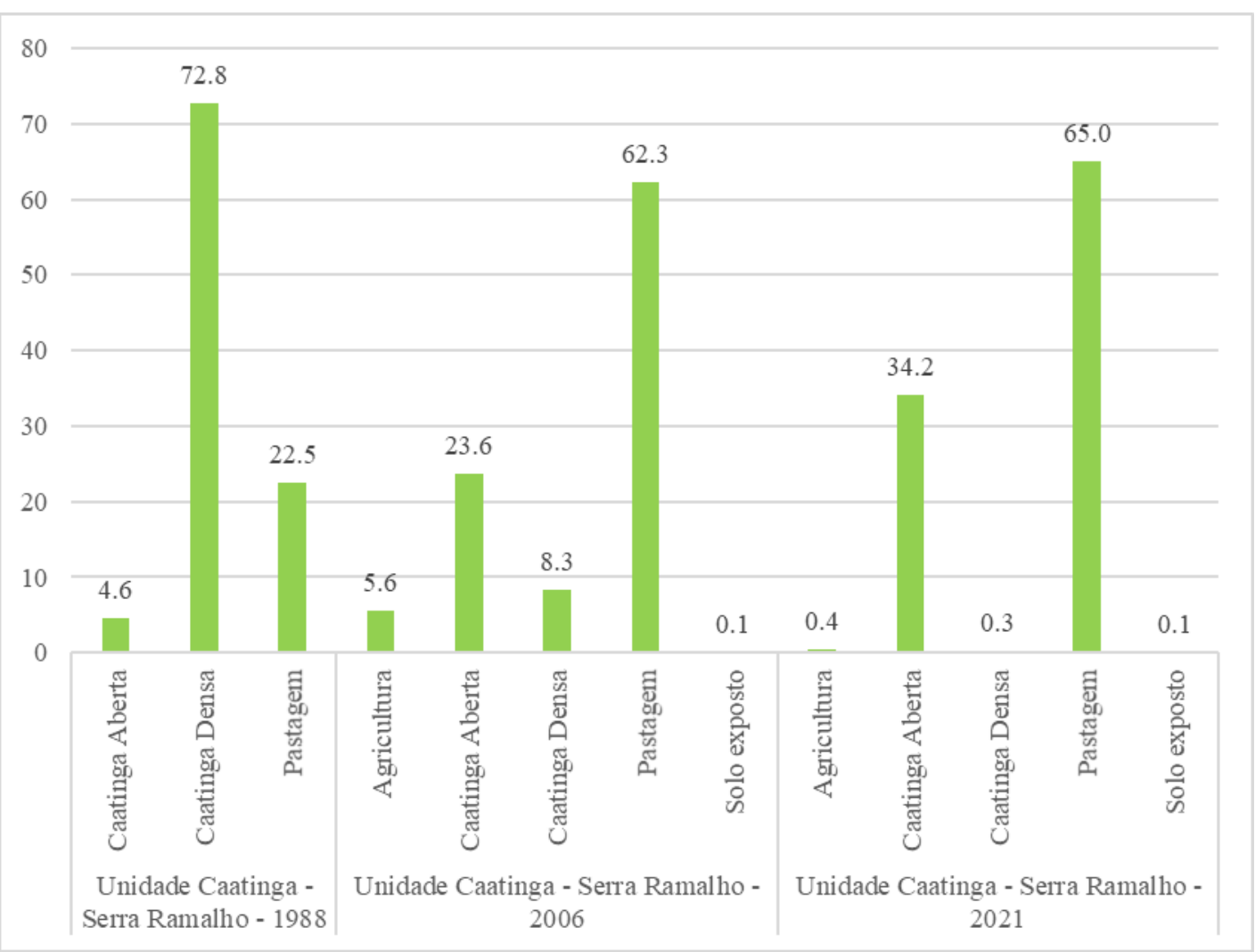

Figura 17- Gráfico da evolução distribuição de cobertura vegetal no assentamento Serra do Ramalho / Unidade de paisagem Caatinga 
No âmbito das comunidades quilombolas/vazanteiras apesar da tendencia predominante em todos os cenários, no quais apontam uma forte tendencia de substituição das matas de caatinga densa por caatinga aberta e pastagem. A unidade caatinga nas comunidades quilombolas ainda preservaram $25,1 \%$ das áreas de caatinga densa, os índices relativos a presença de pastagem na paisagem também apresentou um caráter de preservação das paisagens, ao longo do período estudado a área da unidade de caatinga nas comunidades tiveram aumento de somente 5,7\%.

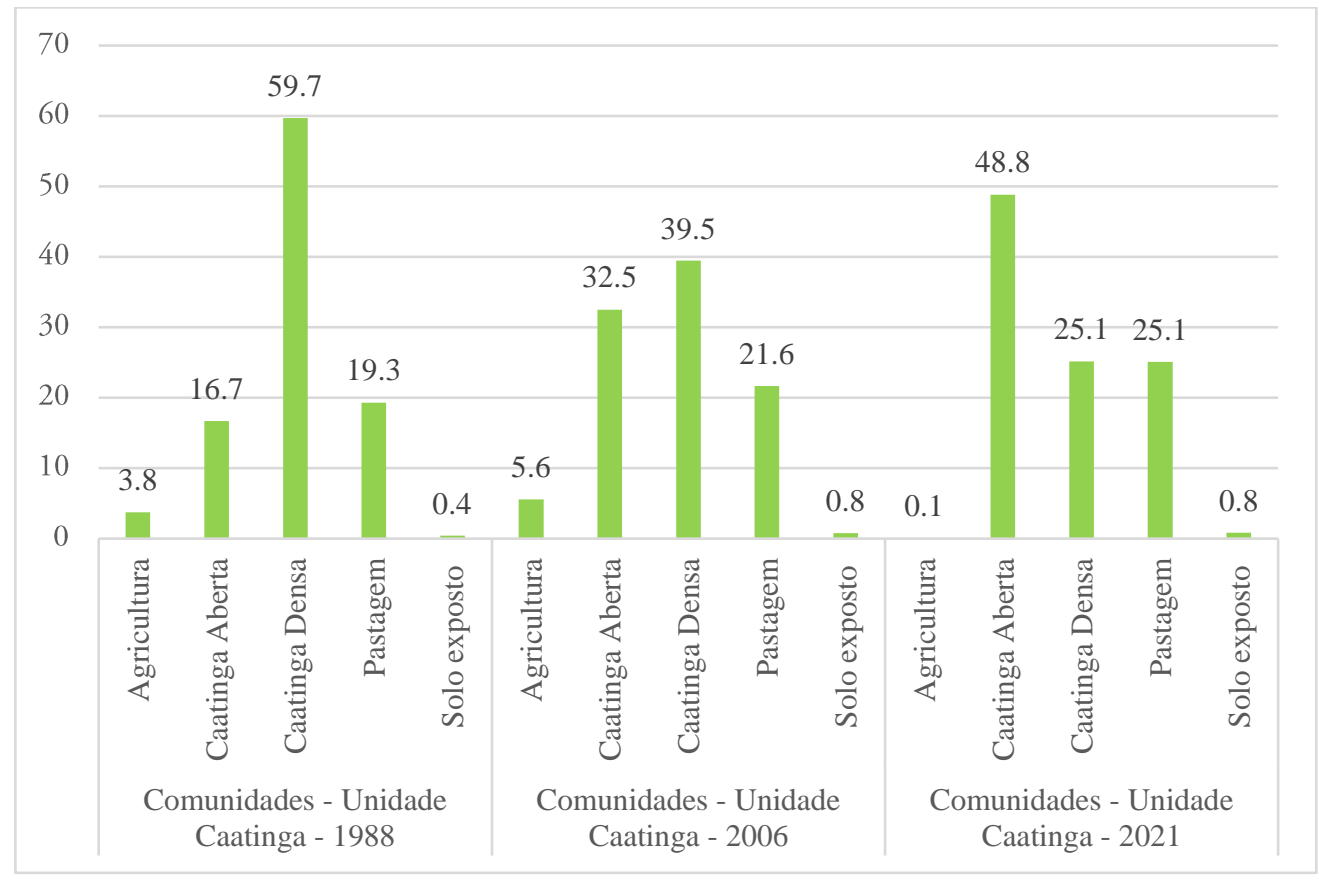

Figura 18- Gráfico da evolução distribuição de cobertura vegetal nas comunidades quilombolas / Unidade de paisagem Caatinga

No âmbito das análises de detecção de mudanças de cobertura vegetal as tendencias gerais ficam expostas indicando os direcionamentos dos processos ambientais e suas intensidades, movimentos de desmatamentos ou resiliência dos fragmentos vegetais são facilmente identificados com essa metodologia. Dessa forma, a unidade paisagem Caatinga apresentou uma grande variação nos diversos recortes. Pelo prisma da análise de perda e ganhos os três recortes tiveram evoluções na presença de cobertura vegetal específicas para cada cenário.

No recorte do buffer de $20 \mathrm{Km}$ foi observado uma contrastante mudança de comportamento entre o período 1985/2007 e 2007/2021, enquanto o primeiro 
período de análise apresentou um forte direcionamento ao desmatamento da vegetação caatinga com perdas de $29,5 \%$ das matas da unidade de paisagem, o segundo período foi caracterizado por um movimento contrário indicando um intenso período de recuperação das perdas vegetais, com índices de 20,4\%. Já nos limites do assentamento de Serra do Ramalho, a unidade de caatinga apresentou saldo de perdas nos dois períodos estudados, apresentando uma massiva perda de $45,3 \%$ no primeiro período e uma recuperação de apenas $2,8 \%$ no segundo. Há de se destacar os dados apresentados pelas comunidades quilombos, os quais apresentaram uma notável índice de resiliência pois mesmo no período de maior perda de vegetação $(11,1 \%)$ ainda contrabalanceou com ganhos de $6,6 \%$, e no viés de recuperação da matas fou o recorte que apresentou maior alta com $31 \%$.

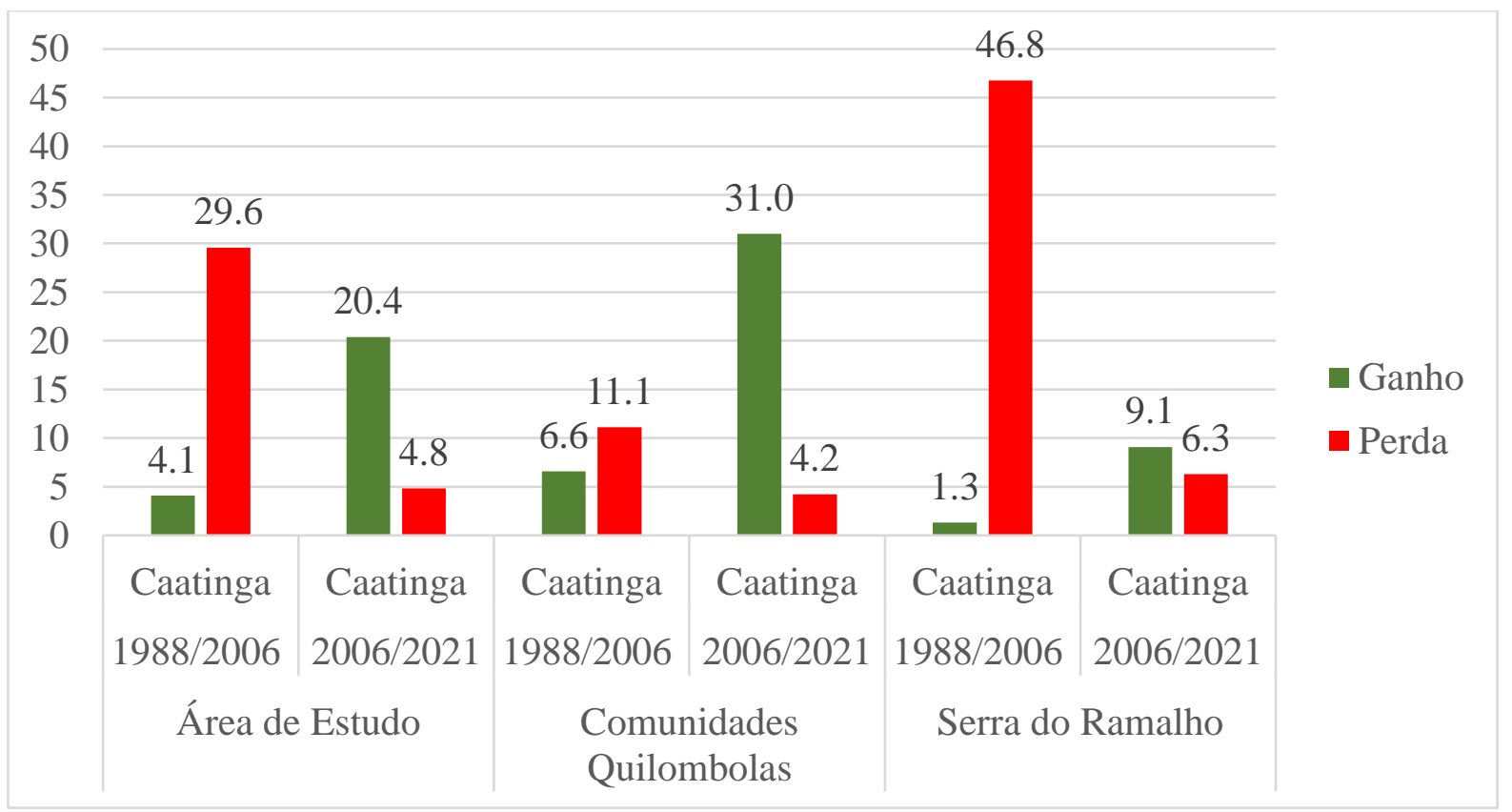

Figura 19- Gráfico da evolução de detecção de mudanças de cobertura vegetal nos diferentes recortes, em \% da área da unidade de paisagem Caatinga

A análise da cobertura vegetal em área da unidade caatinga apontou grande variabilidade de acordo com o recorte espacial. O padrão de cobertura e suas composições são fortemente influenciadas pelos agentes sociais modeladores do espaço. 


\begin{tabular}{|c|c|c|c|c|c|c|}
\hline \multicolumn{7}{|c|}{ Unidade Caatinga } \\
\hline Categoria & Classe & Área (ha) & \begin{tabular}{|l|} 
Dristibuição \\
$(\%)$
\end{tabular} & $\begin{array}{l}\text { Número de } \\
\text { Patches (NP) }\end{array}$ & $\begin{array}{l}\text { Densidade } \\
\text { Patchts } \\
\text { (DP) } \\
\end{array}$ & LPI \\
\hline \multirow{6}{*}{$\begin{array}{c}\text { Comunidades - } \\
\text { Unidade Caatinga - } \\
1988\end{array}$} & Caatinga Aberta & 6179,85 & 16,7025 & 1581 & 4,273 & 1,8835 \\
\hline & Caatinga Densa & 22093,38 & 59,7127 & 1043 & 2,819 & 12,9682 \\
\hline & Pastagem & 7145,73 & 19,3131 & 1038 & 2,8054 & 9,4577 \\
\hline & Solo exposto & 147,6 & 0,3989 & 3 & 0,0081 & 0,3972 \\
\hline & Água & 39,06 & 0,1056 & 2 & 0,0054 & 0,054 \\
\hline & Agricultura & 1393,83 & 3,7672 & 1 & 0,0027 & 3,7672 \\
\hline \multirow{6}{*}{$\begin{array}{l}\text { Comunidades - } \\
\text { Unidade Caatinga - } \\
2006\end{array}$} & Caatinga Densa & 14581,44 & 39,4535 & 1017 & 2,7517 & 11,6008 \\
\hline & Caatinga Aberta & 12015,09 & 32,5096 & 889 & 2,4054 & 8,6911 \\
\hline & Pastagem & 7998,3 & 21,6412 & 711 & 1,9238 & 10,1902 \\
\hline & Agricultura & 2070 & 5,6009 & 42 & 0,1136 & 5,285 \\
\hline & Solo exposto & 284,31 & 0,7693 & 32 & 0,0866 & 0,1619 \\
\hline & Água & 9,45 & 0,0256 & 9 & 0,0244 & 0,009 \\
\hline \multirow{6}{*}{$\begin{array}{c}\text { Comunidades - } \\
\text { Unidade Caatinga - } \\
2021\end{array}$} & Caatinga Aberta & 18047,88 & 48,8327 & 232 & 0,6277 & 22,2128 \\
\hline & Pastagem & 9267,93 & 25,0765 & 189 & 0,5114 & 11,7789 \\
\hline & Caatinga Densa & 9290,61 & 25,1379 & 184 & 0,4979 & 4,6716 \\
\hline & Solo exposto & 307,98 & 0,8333 & 29 & 0,0785 & 0,1619 \\
\hline & Água & 15,48 & 0,0419 & 8 & 0,0216 & 0,0149 \\
\hline & Agricultura & 28,71 & 0,0777 & 5 & 0,0135 & 0,0489 \\
\hline \multirow{8}{*}{$\begin{array}{l}\text { Unidade Caatinga - } \\
\text { Área de Estudo - } 1988\end{array}$} & Caatinga Aberta & 46507,86 & 14,0762 & 11937 & 3,6129 & 1,7542 \\
\hline & Pastagem & 62744,49 & 18,9905 & 11906 & 3,6035 & 2,1777 \\
\hline & Caatinga Densa & 216700,02 & 65,5872 & 7148 & 2,1634 & 26,2168 \\
\hline & Urbano & 392,67 & 0,1188 & 74 & 0,0224 & 0,0355 \\
\hline & Pastagem & 55,44 & 0,0168 & 59 & 0,0179 & 0,0028 \\
\hline & Água & 254,07 & 0,0769 & 46 & 0,0139 & 0,0214 \\
\hline & Agricultura & 3531,96 & 1,069 & 6 & 0,0018 & 0,5449 \\
\hline & Solo exposto & 213,48 & 0,0646 & 4 & 0,0012 & 0,0494 \\
\hline \multirow{7}{*}{$\begin{array}{l}\text { Unidade Caatinga - } \\
\text { Área de Estudo - } 2006\end{array}$} & Caatinga Densa & 72452,97 & 21,9344 & 9035 & 2,7353 & 2,3044 \\
\hline & Caatinga Aberta & 106473,42 & 32,2337 & 8378 & 2,5364 & 4,4292 \\
\hline & Pastagem & 130614,66 & 39,5423 & 4961 & 1,5019 & 15,5351 \\
\hline & Agricultura & 18851,22 & 5,707 & 2146 & 0,6497 & 1,8276 \\
\hline & Solo exposto & 1039,05 & 0,3146 & 130 & 0,0394 & 0,0181 \\
\hline & Água & 272,25 & 0,0824 & 50 & 0,0151 & 0,0251 \\
\hline & Urbano & 613,08 & 0,1856 & 5 & 0,0015 & 0,1656 \\
\hline \multirow{3}{*}{$\begin{array}{l}\text { Unidade Caatinga - } \\
\text { Área de Estudo - } 2021\end{array}$} & Caatinga Aberta & 144697,23 & 43,8069 & 2808 & 0,8501 & 11,2308 \\
\hline & Pastagem & 133474,59 & 40,4093 & 1215 & 0,3678 & 19,181 \\
\hline & Caatinga Densa & 43104,06 & 13,0497 & 1034 & 0,313 & 1,2666 \\
\hline
\end{tabular}




\begin{tabular}{|c|c|c|c|c|c|c|}
\hline & Solo exposto & 1056,69 & 0,3199 & 108 & 0,0327 & 0,0181 \\
\hline & Agricultura & 6775,2 & 2,0512 & 73 & 0,0221 & 1,571 \\
\hline & Água & 320,85 & 0,0971 & 38 & 0,0115 & 0,0275 \\
\hline & Pastagem & 202,95 & 0,0614 & 16 & 0,0048 & 0,0183 \\
\hline & Urbano & 675,45 & 0,2045 & 2 & 0,0006 & 0,185 \\
\hline \multirow{5}{*}{$\begin{array}{l}\text { Unidade Caatinga - } \\
\text { Serra Ramalho - } 1988\end{array}$} & Pastagem & 22770,63 & 22,5193 & 5111 & 5,0546 & 2,5682 \\
\hline & Caatinga Aberta & 4684,23 & 4,6325 & 4166 & 4,12 & 0,0939 \\
\hline & Caatinga Densa & 73596,78 & 72,7844 & 2193 & 2,1688 & 62,3144 \\
\hline & Água & 14,85 & 0,0147 & 13 & 0,0129 & 0,0083 \\
\hline & Urbano & 49,68 & 0,0491 & 1 & 0,001 & 0,0491 \\
\hline \multirow{6}{*}{$\begin{array}{l}\text { Unidade Caatinga - } \\
\text { Serra Ramalho - } 2006\end{array}$} & Caatinga Aberta & 23887,17 & 23,6248 & 3830 & 3,7879 & 1,3151 \\
\hline & Caatinga Densa & 8399,34 & 8,3071 & 3479 & 3,4408 & 0,2527 \\
\hline & Agricultura & 5704,11 & 5,6415 & 1701 & 1,6823 & 1,546 \\
\hline & Pastagem & 62964,99 & 62,2734 & 1366 & 1,351 & 50,3809 \\
\hline & Solo exposto & 123,48 & 0,1221 & 22 & 0,0218 & 0,0271 \\
\hline & Água & 31,5 & 0,0312 & 10 & 0,0099 & 0,0144 \\
\hline \multirow{6}{*}{$\begin{array}{l}\text { Unidade Caatinga - } \\
\text { Serra Ramalho - } 2021\end{array}$} & Caatinga Aberta & 34538,13 & 34,1588 & 1314 & 1,2996 & 10,3282 \\
\hline & Pastagem & 65695,32 & 64,9738 & 186 & 0,184 & 54,8713 \\
\hline & Caatinga Densa & 297,9 & 0,2946 & 42 & 0,0415 & 0,0601 \\
\hline & Agricultura & 407,07 & 0,4026 & 34 & 0,0336 & 0,1309 \\
\hline & Solo exposto & 134,73 & 0,1333 & 21 & 0,0208 & 0,0271 \\
\hline & Água & 37,35 & 0,0369 & 8 & 0,0079 & 0,0155 \\
\hline
\end{tabular}

Quadro 3 - Métricas da paisagem das áreas de estudo, comunidades quilombolas e assentamento Serra do Ramalho - Unidade de paisagem Caatinga

\subsection{2 - Unidade tabuleiro}

A unidade de paisagem Tabuleiro tem sua representação geomorfológica na categoria do Terraços Fluviais, uma superfície horizontal, constituída por uma área de depósito sedimentar, tem como principal a característica sua inundação nos períodos de grandes cheias. Os tabuleiros são parte importante da cultura vazanteira por ser a principal área de habitação.

A distribuição da variedade fitofisionômica nas áreas dos tabuleiros no buffer de $20 \mathrm{Km}$, segundo os dados processados, apresentou a mesma tendência relativa a troca da vegetação de caatinga densa por caatinga aberta, os quais apontavam uma distribuição mais igualitária entre tais classes em 1988, sendo 
41,3\% e 41,4\% respectivamente. Já em 2021, tal distribuição contava 54,8\% de caatinga aberta e 16,6\% de área de caatinga densa. É importante observar que diferentemente dos outros recortes anteriores, a de cobertura de pastagem na unidade tabuleiro não teve um forte crescimento, passando de $15,6 \%$ para $21,9 \%$.

No campo dos outros indicadores, o índice LPI indica a forte presença de cobertura vegetal do tipo caatinga aberta em 1988, o qual indica aponta que o maior fragmento representava $14,2 \%$ de toda área dos tabuleiros, enquanto o maior fragmento de caatinga densa alcançava no período 8,5\% da área total. Em 2021, o maior fragmento também pertencia a caatinga densa, com 20,3\% das áreas dos tabuleiros, neste cenário o maior fragmento de caatinga densa na área do buffer de $20 \mathrm{Km}$ correspondia a apenas a $2 \%$ da área da unidade tabuleiro.

Em termos de fragmentação os índices de também apontam que a caatinga aberta tinha uma densidade de 2,8 patches/100 ha, e caatinga densa contava com 4,9 patches/100 ha desse modo sendo duas vezes menor em 1988. Em 2021, o índice pra caatinga aberta para 1,1 patches/100 ha, ao passo que a caatinga densa passa para apenas para 0,6 patches $/ 100$ ha indicando o domínio na paisagem dos tabuleiros do tipo de vegetação menos cerrada de caatinga.

Da perspectiva dos recortes menores da paisagem a área de tabuleiro de Serra do Ramalho apresenta dados bem diferente da unidade de caatinga, sobretudo na distribuição da vegetação de caatinga densa. Tal categoria fitofisionômica representava 66,6\% da área dos tabuleiros em 1988, apresentando uma pequena redução em 2006 contando com 60,2\%, um comportamento bem diferente dos cenários apresentados anteriormente, onde o período de 1988-2006 é marcado por uma alta substituição da caatinga densa por caatinga aberta ou pastagem. Outro dado expressivo é a presença de caatinga densa ainda em 2021, tendo em vista que nas áreas da unidade de caatinga tal vegetação está praticamente extinta. 


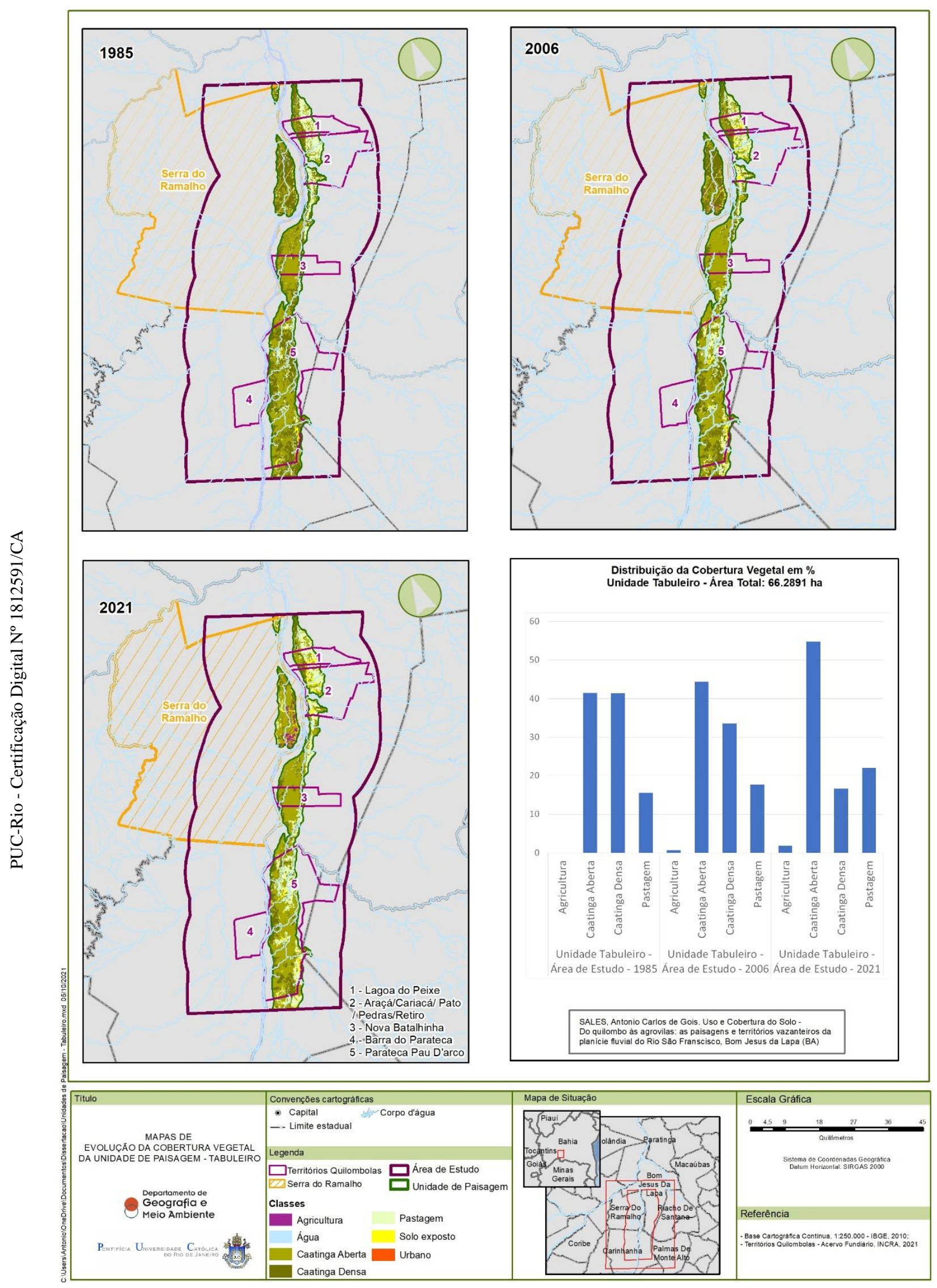

Figura 20 - Mapa de evolução de cobertura vegetal da unidade tabuleiro 
Os indicadores de fragmentação da cobertura vegetal do tabuleiro de Serra do Ramalho indicaram a forte presença de caatinga densa neste território, em 1985 o maior fragmento desta fitofisionomia compunha $59,6 \%$ da área total do tabuleiro pertencente assentamento, passando para 30\% em 2006 e atingido 2,4\% em 2021. Ao passo que os maiores fragmentos de caatinga aberta trilharam o caminho inverso, passando de 4\% em 1988 para 52\% no ano de 2021. A presença de classe de pastagem é um importante indicador de antropização de um ambiente, dessa forma, vale ressaltar a baixa presença deste tipo de vegetação tendo uma pequena evolução do tamanho máximo dos fragmentos de $0,5 \%$, para $2,1 \%$ e apenas 83 patches na área do tabuleiro.

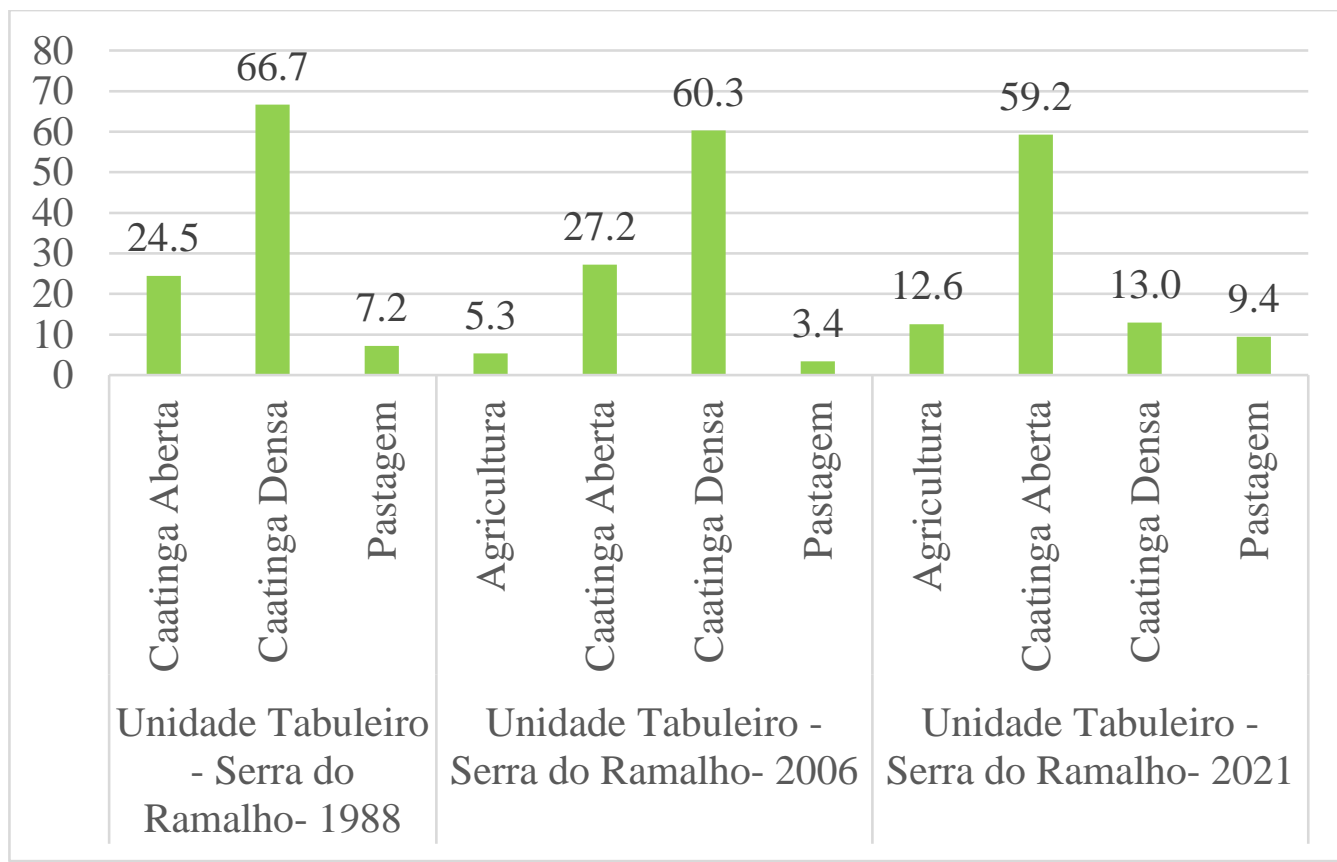

Figura 21- Gráfico da evolução distribuição de cobertura vegetal em Serra do Ramalho / Unidade de paisagem Tabuleiro

No recorte das comunidades quilombolas os dados indicaram diferenças estruturais em relação aos outros focos de análises. A orientação de substituição entre as classes de caatinga densa e caatinga aberta também permanece como uma constante na unidade tabuleiro das comunidade quilombolas À medida que o buffer de $20 \mathrm{Km}$ apresentou um leve aumento da participação da agricultura em tal recorte apenas 1\% em 2021, a área do assentamento de Serra do Ramalho uma grande elevação da proporção da classe de agricultura em seu tabuleiros chegando a 12,5\% 
no mesmo período. Já nos territórios das comunidades quilombolas não foi identificado em nenhum cenário a presença de áreas agrícolas em tal unidade de paisagem.

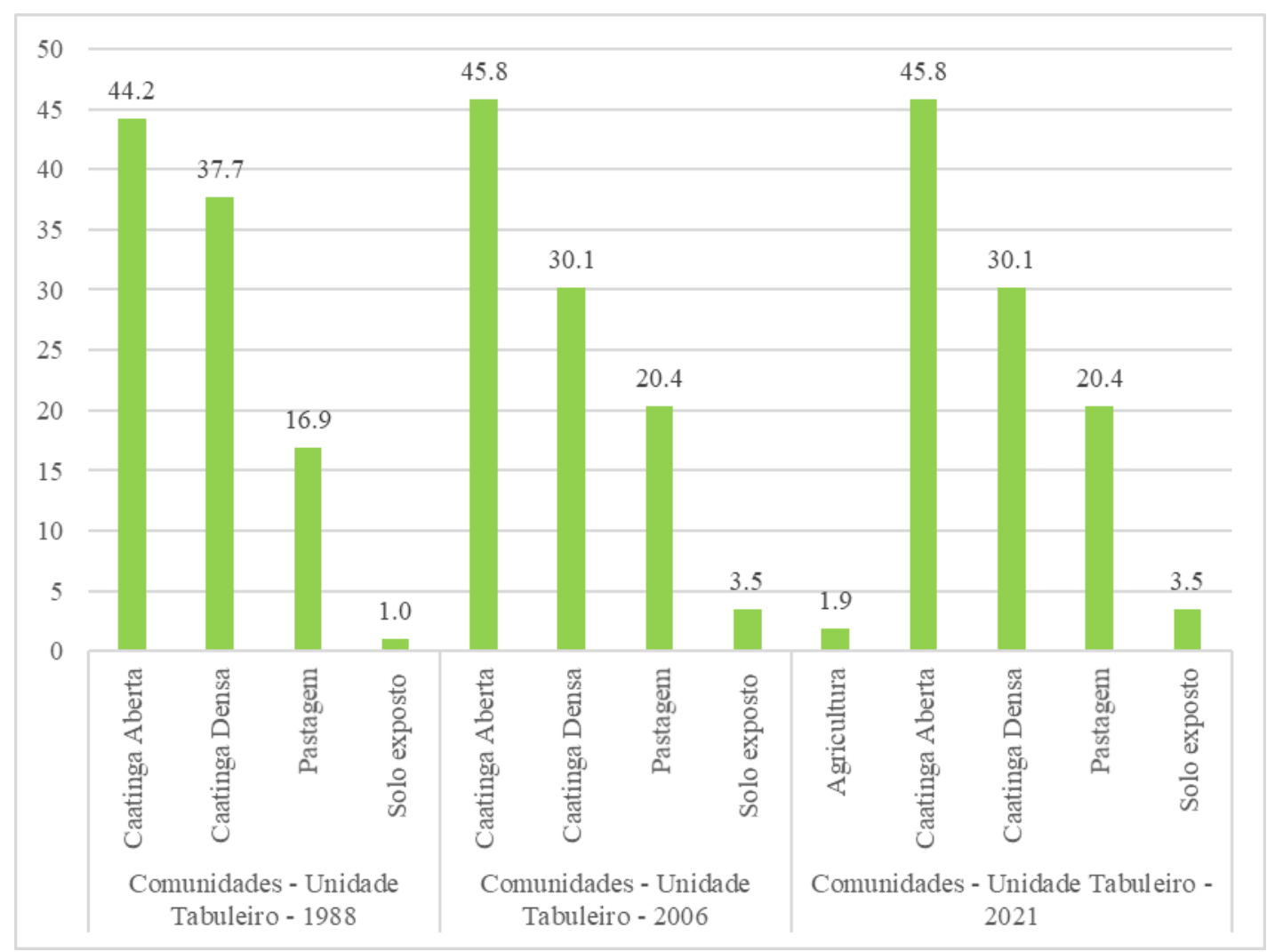

Figura 22- Gráfico da evolução distribuição de cobertura vegetal na Comunidades Quilombolas / Unidade de paisagem Tabuleiro

Análise de perda e ganhos nas áreas de tabuleiro apontaram para um baixo nível de intensidade do processo de desmatamento, considerando o recorte da unidade caatinga. $\mathrm{Na}$ escala do buffer de $20 \mathrm{Km}$, análise indicou um pequeno ganho de 5,4\% cobertura vegetal nos tabuleiros de toda a área de estudos ao longo de todos os períodos estudado, ao mesmo tempo que as comunidades quilombolas apresentaram ganhos de 6,8\% da cobertura vegetal nas áreas de tabuleiro. Já no caso do assentamento Serra do Ramalho, os tabuleiros apresentaram dados que apontam uma elevação do ritmo de desflorestamento, ao passo que em nos períodos de análises apresentou perdas de 5,7\% da cobertura vegetal dos tabuleiros, uma tendencia isolada. 


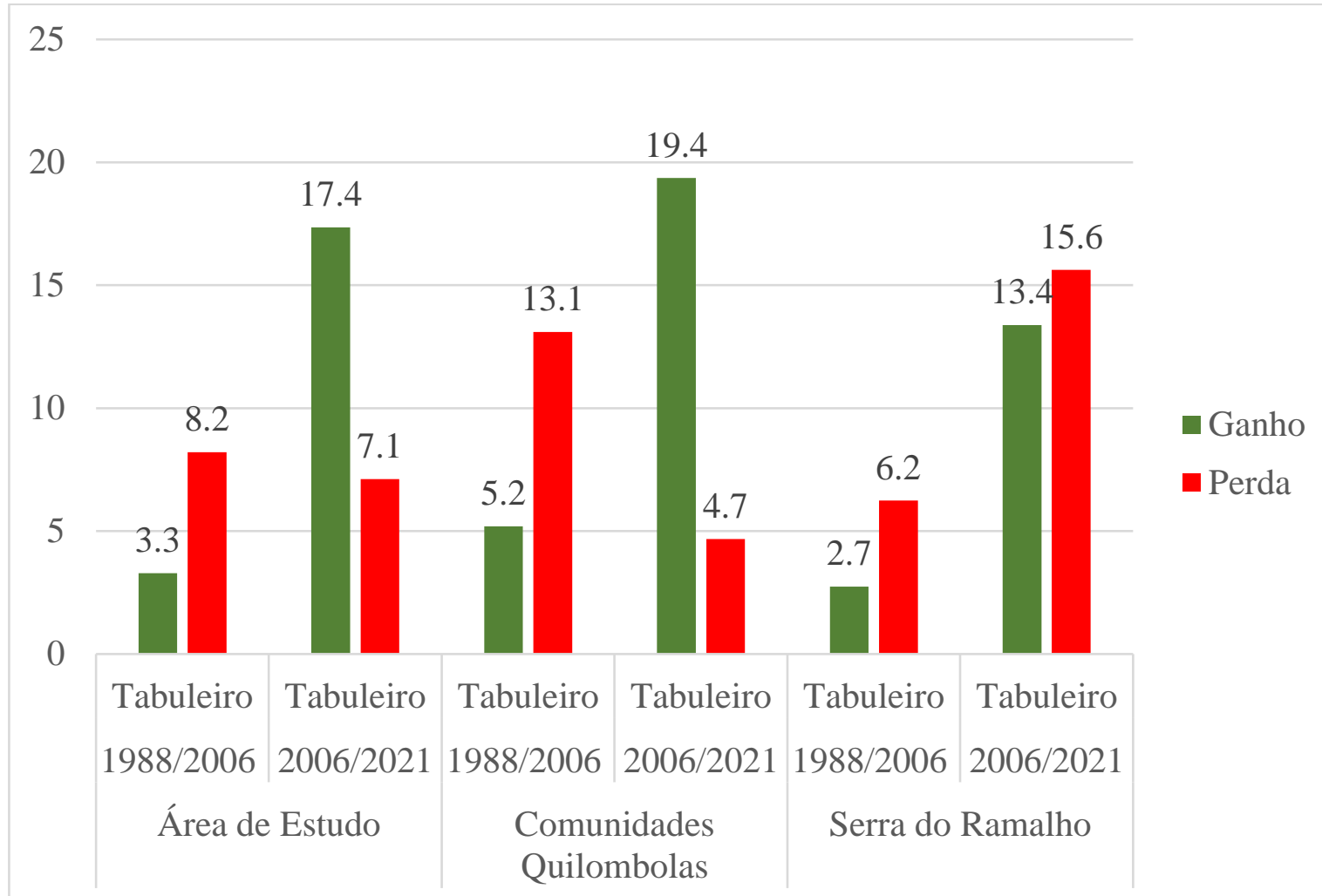

Figura 23- Gráfico da evolução de detecção de mudanças de cobertura vegetal nos diferentes recortes, em \% da área da unidade de paisagem Tabuleiro

\begin{tabular}{|c|c|c|c|c|c|c|}
\hline \multicolumn{7}{|c|}{ Unidade Tabuleiro } \\
\hline Categoria & Classe & $\begin{array}{l}\text { Área } \\
\text { (ha) }\end{array}$ & $\begin{array}{l}\text { Dristibuição } \\
(\%)\end{array}$ & $\begin{array}{l}\text { Número de } \\
\text { Patches (NP) }\end{array}$ & $\begin{array}{l}\text { Densidade } \\
\text { Patchts (DP) }\end{array}$ & LPI \\
\hline \multirow{5}{*}{$\begin{array}{l}\text { Comunidades - } \\
\text { Unidade } \\
\text { Tabuleiro - } 1988\end{array}$} & Caatinga Densa & 13851,54 & 37,7356 & 1772 & 4,8274 & 10,8916 \\
\hline & Caatinga Aberta & 16235,73 & 44,2308 & 813 & 2,2148 & 24,8753 \\
\hline & Pastagem & 6214,32 & 16,9296 & 806 & 2,1958 & 5,2014 \\
\hline & Água & 21,33 & 0,0581 & 54 & 0,1471 & 0,0135 \\
\hline & Solo exposto & 383,94 & 1,046 & 7 & 0,0191 & 0,4725 \\
\hline \multirow{6}{*}{$\begin{array}{l}\text { Comunidades - } \\
\text { Unidade } \\
\text { Tabuleiro - } 2006\end{array}$} & Caatinga Densa & 11065,59 & 30,146 & 1496 & 4,0756 & 3,6555 \\
\hline & Caatinga Aberta & 16825,23 & 45,837 & 703 & 1,9152 & 25,4801 \\
\hline & Pastagem & 7475,85 & 20,3665 & 643 & 1,7517 & 5,6775 \\
\hline & Solo exposto & 1289,88 & 3,514 & 140 & 0,3814 & 0,3097 \\
\hline & Água & 50,13 & 0,1366 & 19 & 0,0518 & 0,0745 \\
\hline & Caatinga Densa & 11065,59 & 30,1458 & 1496 & 4,0755 & 3,6555 \\
\hline
\end{tabular}




\begin{tabular}{|c|c|c|c|c|c|c|}
\hline \multirow{5}{*}{$\begin{array}{l}\text { Comunidades - } \\
\text { Unidade } \\
\text { Tabuleiro - } 2021\end{array}$} & Caatinga Aberta & 16825,5 & 45,8375 & 704 & 1,9179 & 25,48 \\
\hline & Pastagem & 7475,76 & 20,3661 & 643 & 1,7517 & 5,6775 \\
\hline & Solo exposto & 1289,88 & 3,514 & 140 & 0,3814 & 0,3097 \\
\hline & Agricultura & 1166,94 & 1,9314 & 30 & 0,0497 & 0,8534 \\
\hline & Água & 50,13 & 0,1366 & 19 & 0,0518 & 0,0745 \\
\hline \multirow{7}{*}{$\begin{array}{c}\text { Unidade } \\
\text { Tabuleiro - Área } \\
\text { de Estudo - } 1988\end{array}$} & Caatinga Densa & 27410,49 & 41,3501 & 3252 & 4,9058 & 8,5269 \\
\hline & Pastagem & 10357,29 & 15,6245 & 1848 & 2,7878 & 6,4505 \\
\hline & Caatinga Aberta & 27481,23 & 41,4568 & 1857 & 2,8014 & 14,2075 \\
\hline & Urbano & 82,71 & 0,1248 & 12 & 0,0181 & 0,1111 \\
\hline & Água & 463,68 & 0,6995 & 247 & 0,3726 & 0,2161 \\
\hline & Agricultura & 0,09 & 0,0001 & 1 & 0,0015 & 0,0001 \\
\hline & Solo exposto & 493,38 & 0,7443 & 7 & 0,0106 & 0,3306 \\
\hline \multirow{7}{*}{$\begin{array}{c}\text { Unidade } \\
\text { Tabuleiro - Área } \\
\text { de Estudo - } 2006\end{array}$} & Caatinga Densa & 22220,1 & 33,5195 & 2659 & 4,0112 & 4,3732 \\
\hline & Pastagem & 11700,63 & 17,6507 & 1224 & 1,8464 & 4,8649 \\
\hline & Caatinga Aberta & 29410,47 & 44,3663 & 1570 & 2,3684 & 14,5573 \\
\hline & Urbano & 79,65 & 0,1202 & 3 & 0,0045 & 0,1172 \\
\hline & Solo exposto & 1899,18 & 2,865 & 236 & 0,356 & 0,1768 \\
\hline & Água & 474,21 & 0,7154 & 125 & 0,1886 & 0,1397 \\
\hline & Agricultura & 505,8 & 0,763 & 295 & 0,445 & 0,0506 \\
\hline \multirow{7}{*}{$\begin{array}{c}\text { Unidade } \\
\text { Tabuleiro - Área } \\
\text { de Estudo - } 2021\end{array}$} & Pastagem & 14565,42 & 21,9729 & 301 & 0,4541 & 4,6688 \\
\hline & Caatinga Aberta & 36353,07 & 54,8411 & 731 & 1,1028 & 20,3551 \\
\hline & Caatinga Densa & 11032,02 & 16,6426 & 439 & 0,6623 & 1,999 \\
\hline & Agricultura & 1224,09 & 1,8466 & 31 & 0,0468 & 0,7778 \\
\hline & Urbano & 84,24 & 0,1271 & 6 & 0,0091 & 0,1066 \\
\hline & Água & 717,12 & 1,0818 & 99 & 0,1493 & 0,214 \\
\hline & Solo exposto & 2312,01 & 3,4878 & 137 & 0,2067 & 0,1982 \\
\hline \multirow{4}{*}{$\begin{array}{c}\text { Unidade } \\
\text { Tabuleiro - Serra } \\
\text { do Ramalho- } \\
1988\end{array}$} & Caatinga Densa & 6314,04 & 66,6838 & 331 & 3,4958 & 59,6956 \\
\hline & Caatinga Aberta & 2316,24 & 24,4623 & 486 & 5,1327 & 4,0995 \\
\hline & Pastagem & 684,99 & 7,2343 & 454 & 4,7948 & 0,5617 \\
\hline & Água & 153,36 & 1,6197 & 98 & 1,035 & 0,173 \\
\hline \multirow{6}{*}{$\begin{array}{l}\text { Unidade } \\
\text { Tabuleiro - Serra } \\
\text { do Ramalho- } \\
2006\end{array}$} & Caatinga Densa & 5708,34 & 60,2731 & 394 & 4,1602 & 30,6098 \\
\hline & Caatinga Aberta & 2576,07 & 27,2002 & 424 & 4,4769 & 11,1374 \\
\hline & Pastagem & 323,64 & 3,4172 & 169 & 1,7844 & 1,5889 \\
\hline & Água & 47,97 & 0,5065 & 22 & 0,2323 & 0,0979 \\
\hline & Agricultura & 505,8 & 5,3406 & 295 & 3,1148 & 0,3545 \\
\hline & Solo exposto & 308,97 & 3,2623 & 46 & 0,4857 & 0,7308 \\
\hline \multirow{6}{*}{$\begin{array}{c}\text { Unidade } \\
\text { Tabuleiro - Serra } \\
\text { do Ramalho- } \\
2021\end{array}$} & Caatinga Aberta & 5610,87 & 59,2439 & 147 & 1,5521 & 52,0217 \\
\hline & Agricultura & 1191,15 & 12,5771 & 31 & 0,3273 & 5,4442 \\
\hline & \begin{tabular}{|l|} 
Pastagem \\
\end{tabular} & 891 & 9,4079 & 58 & 0,6124 & 2,1344 \\
\hline & Caatinga Densa & 1228,59 & 12,9724 & 83 & 0,8764 & 2,4869 \\
\hline & Água & 98,1 & 1,0358 & 26 & 0,2745 & 0,3687 \\
\hline & Solo exposto & 451,08 & 4,7629 & 24 & 0,2534 & 1,0985 \\
\hline
\end{tabular}


Quadro 4 - - Métricas da paisagem das áreas de estudo, comunidades quilombolas e assentamento Serra do Ramalho - Unidade de paisagem Tabuleir

\subsection{3 - Unidade Lameiro}

A Unidade de paisagem lameiro está associada os processos ambientais presentes na área da planície fluvial do Rio São Francisco, sendo um ambiente intrinsicamente relacionado com os ciclos do canal apresentando respostas instantâneas as alterações de vazão. O lameiro está relacionada as lamas da região dos diques marginais desse modo essa unidade de paisagem tem como principais características ser área de deposição de sedimentos e a alta presença de umidade do solo, desse modo área de grande fertilidade.

Segundo as análise dos dados, os lameiros presentes na área de estudo apresentaram uma evolução da cobertura vegetal diferentemente de todos outros pontos de análise, essa unidade de paisagem foi a única no qual a caatinga densa permaneceu como a fitofisionomia dominante. Apesar de sua consistente diminuição, passando de 59,3\% para 36,8\%, a caatinga densa dos lameiros se destacou por sua grande capacidade de resiliência. Os dados do índice LPI também indicam tal propriedade da vegetação, pois em 1988 o maior fragmento compunha $8 \%$ de toda área dos lameiros, em 2021 esse índice caiu apenas 0,2\%. 


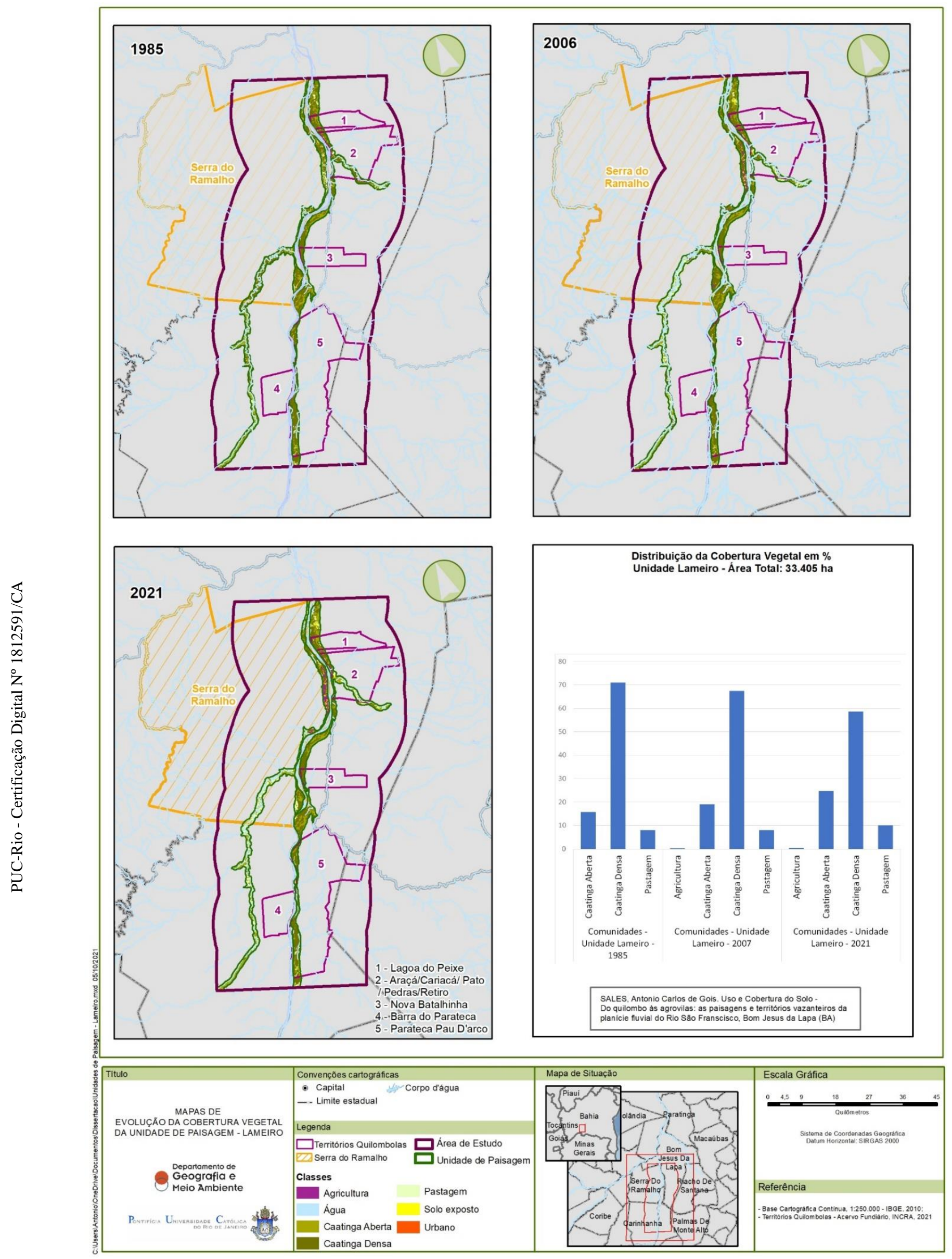

Figura 24- Mapa de evolução de cobertura vegetal da unidade Lameiro 
No assentamento de Serra do Ramalho a vegetação de tabuleiro apresentou um forte avanço da classe de pastagem, passando de $12,5 \%$ para $29 \%$ no período entre 1988 e 2021 tomando lugar da caatinga densa, como tipo de fitofisionomia predominante nesta unidade de paisagem. No entanto, é a unidade de paisagem que, em Serra do Ramalho, manteve o maior índice de preservação da vegetação de caatinga, pois em 1988 contava com 67,9\% de caatinga densa e 17,1\% do tipo aberta, passando para $26,8 \%$ e 28,2 respectivamente. Sob o ponto de vista da análise dos fragmentos em 1988 o maior fragmento em Serra do Ramalho pertencia a classe caatinga densa ocupando 59,6\% da área dos tabuleiros, em 2021, o índice LPI indicou o que o maior fragmento pertencia a classe de caatinga densa com $52 \%$ da área dos lameiros.

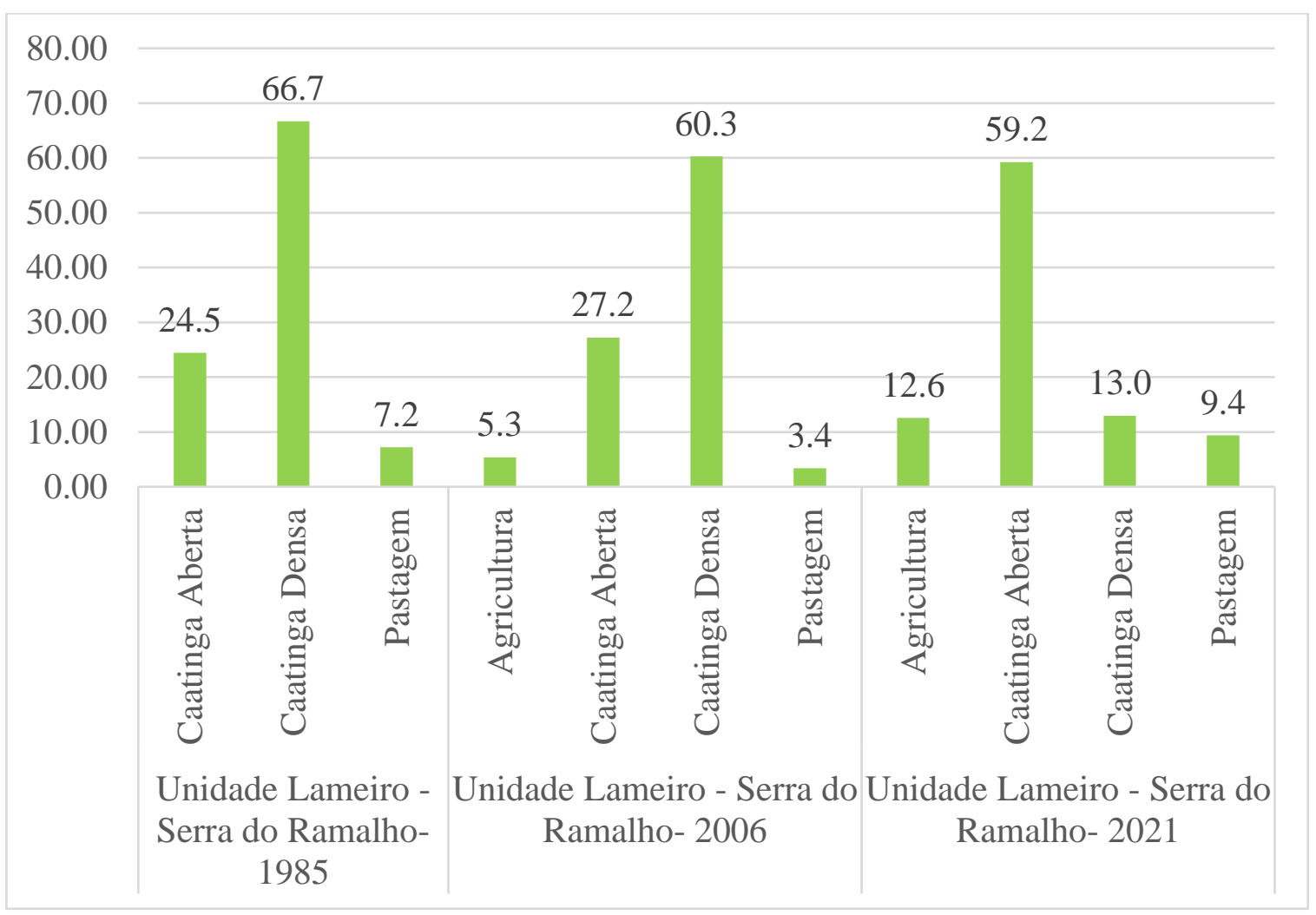

Figura 25- Gráfico da evolução distribuição de cobertura vegetal em Serra do Ramalho / Unidade de paisagem Lameiro

Nas comunidades quilombolas, a capacidade de resiliência das unidade dos lameiros se destacou ainda mais comparativamente aos outros recortes. A caatinga densa marca presença em $71 \%$ das área de lameiros em 1988, e apresentando uma 
pequena perda em 2021 de 12,5\%, mais ainda permanecendo como vegetação dominante nos lameiros quilombolas. Os índices LPI, apresentou que a caatinga densa contava com o maior fragmento em 1988, o qual correspondia a $30 \%$ da área dos lameiro, em 2021 o maior fragmento ainda pertencia mesma classe com um baixa de apenas $0,3 \%$, desmonstrando uma tendencia de estabilidade na evolução da cobertura vegetal de paisagens de lameiros em comunidades quilombolas.

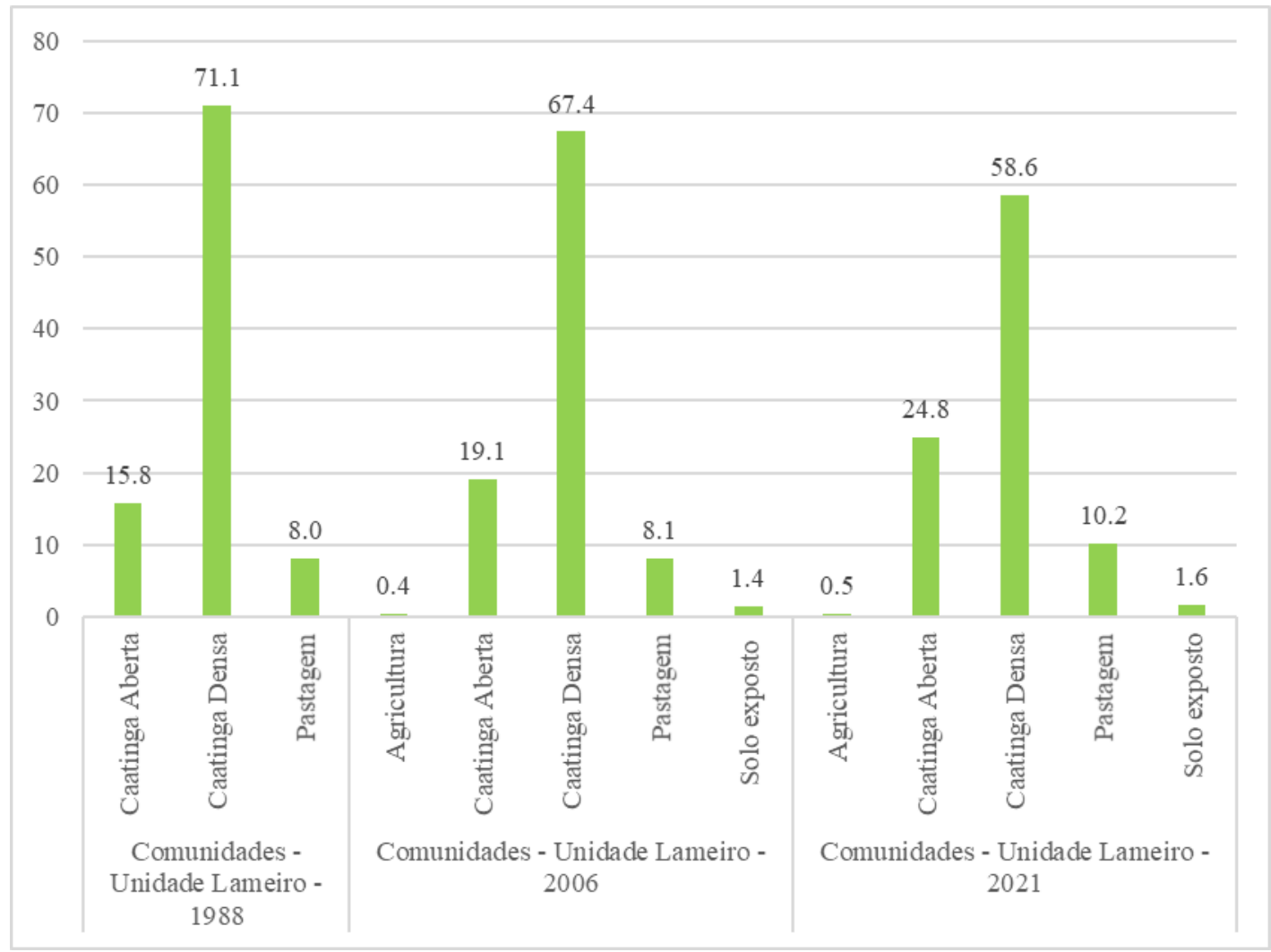

Figura 26 - Gráfico da evolução distribuição de cobertura vegetal em Comunidades Quilombolas / Unidade de paisagem Lameiro

A análise de detecção de mudanças de cobertura vegetal das áreas de lameiro apresentou um contraste entre o comportamento entre os recorte, sobretudo pela forte tendencia de recuperação. Enquanto os lameiros do buffer de $20 \mathrm{Km}$ e de Serra do Ramalho apresentação grandes perdas de cobertura vegetal no período entre 1988 e $2006,12 \%$ e $21,6 \%$ respectivamente, as comunidades quilombolas apresentaram um estabilidade apresentado um balanço de -1,1\%. Já o período entre 2006 e 2021 a tendência de perdas de cobertura vegetal se invertem e todos os 
recortes apresentam um ganhos nas vegetações de lameiro, destacando-se as comunidades quilombolas com o ganhos de $59,2 \%$.

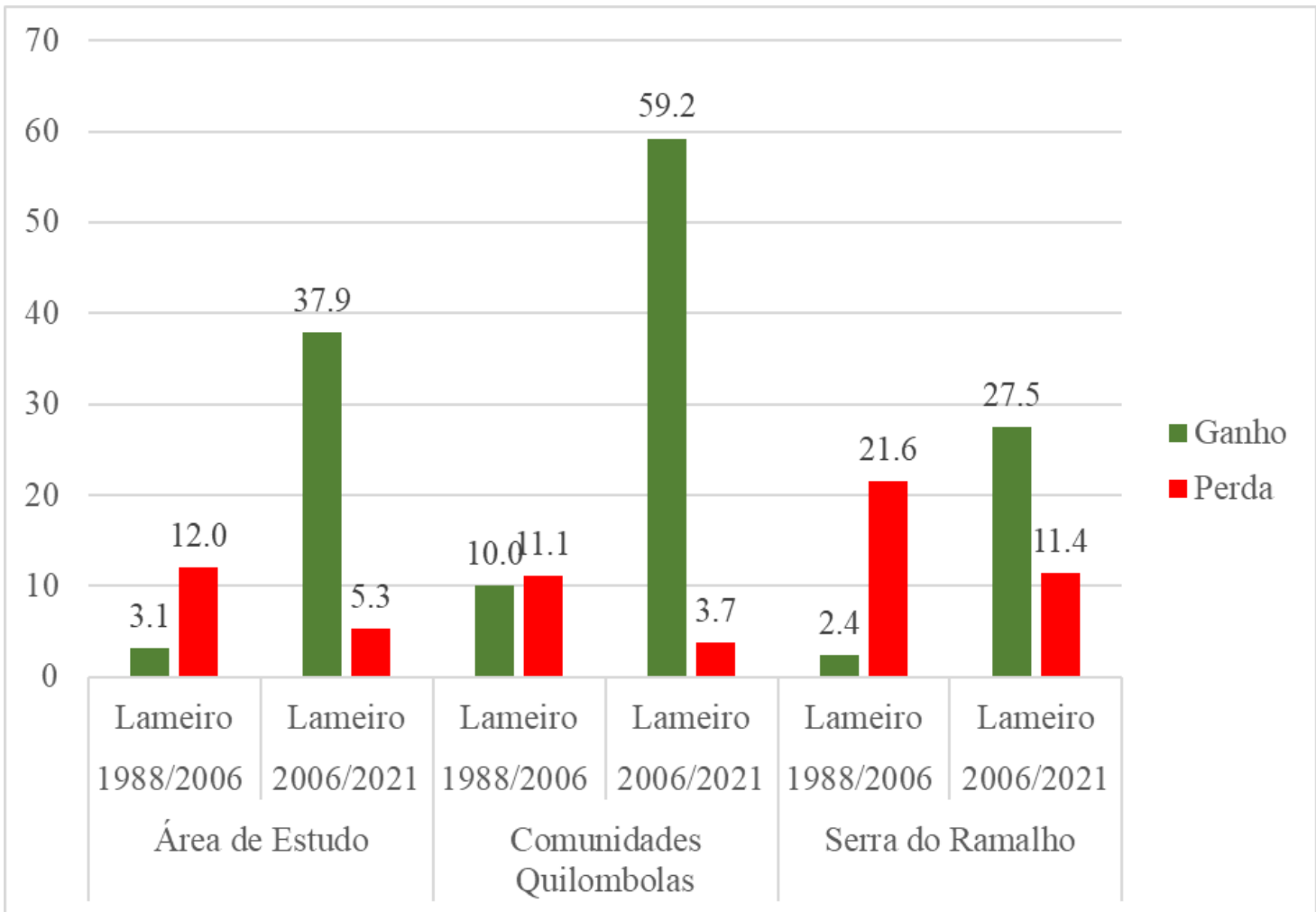

Figura 27 - - Gráfico da evolução de ganhos e perdas de áreas florestadas área de estudo, comunidades quilombolas e assentamento Serra do Ramalho / Unidade de paisagem Lameiro

\begin{tabular}{|c|c|c|c|c|c|c|}
\hline \multicolumn{7}{|c|}{ Unidade Lameiro } \\
\hline Categoria & Classe & $\begin{array}{l}\text { Área } \\
\text { (ha) }\end{array}$ & $\begin{array}{l}\text { Dristibuição } \\
(\%)\end{array}$ & $\begin{array}{l}\text { Número de } \\
\text { Patches (NP) } \\
\end{array}$ & $\begin{array}{l}\text { Densidade } \\
\text { Patchts (DP) } \\
\end{array}$ & LPI \\
\hline \multirow{5}{*}{$\begin{array}{l}\text { Comunidades - } \\
\text { Unidade } \\
\text { Lameiro - } 1988\end{array}$} & Caatinga Aberta & 1236,96 & 15,7613 & 310 & 3,95 & 3,2247 \\
\hline & Caatinga Densa & 5577,39 & 71,0668 & 186 & 2,37 & 30,5535 \\
\hline & Pastagem & 628,47 & 8,0079 & 176 & 2,2426 & 0,8119 \\
\hline & Água & 405,27 & 5,1639 & 37 & 0,4715 & 3,1513 \\
\hline & Caatinga Aberta & 1496,88 & 19,0706 & 275 & 3,5036 & 3,2874 \\
\hline \multirow{4}{*}{$\begin{array}{l}\text { Comunidades - } \\
\text { Unidade } \\
\text { Lameiro - } 2006\end{array}$} & Pastagem & 632,16 & 8,0538 & 145 & 1,8473 & 2,5042 \\
\hline & Caatinga Densa & 5292,36 & 67,4257 & 141 & 1,7964 & 30,3923 \\
\hline & Água & 282,87 & 3,6038 & 37 & 0,4714 & 1,8426 \\
\hline & Solo exposto & 112,77 & 1,4367 & 27 & 0,344 & 0,4151 \\
\hline
\end{tabular}




\begin{tabular}{|c|c|c|c|c|c|c|}
\hline & Agricultura & 32,13 & 0,4093 & 2 & 0,0255 & 0,2775 \\
\hline \multirow{6}{*}{$\begin{array}{l}\text { Comunidades - } \\
\text { Unidade } \\
\text { Lameiro - } 2021\end{array}$} & Caatinga Aberta & 1948,95 & 24,83 & 211 & 2,6882 & 4,2069 \\
\hline & Caatinga Densa & 4598,1 & 58,5807 & 59 & 0,7517 & 29,7823 \\
\hline & Pastagem & 797,04 & 10,1544 & 45 & 0,5733 & 2,9032 \\
\hline & Água & 339,84 & 4,3296 & 40 & 0,5096 & 2,2886 \\
\hline & Solo exposto & 129,15 & 1,6454 & 21 & 0,2675 & 0,493 \\
\hline & Agricultura & 36,09 & 0,4598 & 2 & 0,0255 & 0,3176 \\
\hline \multirow{7}{*}{$\begin{array}{c}\text { Unidade } \\
\text { Lameiro - Área } \\
\text { de Estudo - } 1988\end{array}$} & Caatinga Aberta & 8501,58 & 25,4478 & 1488 & 4,454 & 4,1638 \\
\hline & Pastagem & 3428,1 & 10,2613 & 1443 & 4,3193 & 0,8421 \\
\hline & Caatinga Densa & 19813,32 & 59,3073 & 1234 & 3,6937 & 8,0816 \\
\hline & Água & 1652,67 & 4,9469 & 162 & 0,4849 & 0,9192 \\
\hline & Urbano & 12,24 & 0,0366 & 3 & 0,009 & 0,0221 \\
\hline & Caatinga Aberta & 10371,78 & 31,0471 & 1205 & 3,6071 & 4,8076 \\
\hline & Caatinga Densa & 14993,19 & 44,881 & 930 & 2,7839 & 8,0065 \\
\hline \multirow{7}{*}{$\begin{array}{c}\text { Unidade } \\
\text { Lameiro - Área } \\
\text { de Estudo - } 2006\end{array}$} & Pastagem & 5262,93 & 15,7542 & 516 & 1,5446 & 1,8021 \\
\hline & Agricultura & 1063,08 & 3,1822 & 314 & 0,9399 & 0,9445 \\
\hline & Água & 1194,12 & 3,5745 & 110 & 0,3293 & 0,5876 \\
\hline & Solo exposto & 509,76 & 1,5259 & 82 & 0,2455 & 0,2357 \\
\hline & Pastagem & 11,7 & 0,035 & 3 & 0,009 & 0,0178 \\
\hline & Caatinga Aberta & 11623,5 & 34,7941 & 1000 & 2,9934 & 4,4415 \\
\hline & Pastagem & 6422,13 & 19,2242 & 258 & 0,7723 & 2,6949 \\
\hline \multirow{7}{*}{$\begin{array}{c}\text { Unidade } \\
\text { Lameiro - Área } \\
\text { de Estudo - } 2021\end{array}$} & Caatinga Densa & 12322,98 & 36,8879 & 227 & 0,6795 & 7,8627 \\
\hline & Água & 1393,29 & 4,1707 & 92 & 0,2754 & 0,7134 \\
\hline & Solo exposto & 550,44 & 1,6477 & 73 & 0,2185 & 0,2465 \\
\hline & Agricultura & 1085,58 & 3,2496 & 25 & 0,0748 & 2,2412 \\
\hline & Urbano & 8,64 & 0,0259 & 3 & 0,009 & 0,0137 \\
\hline & Pastagem & 1155,6 & 12,5068 & 643 & 6,9591 & 3,0449 \\
\hline & Caatinga Aberta & 1582,29 & 17,1248 & 514 & 5,5629 & 2,2754 \\
\hline \multirow{4}{*}{$\begin{array}{c}\text { Unidade } \\
\text { Lameiro - Serra } \\
\text { do Ramalho- } \\
1988\end{array}$} & Caatinga Densa & 6274,53 & 67,9079 & 368 & 3,9828 & 22,5308 \\
\hline & Água & 227,34 & 2,4605 & 44 & 0,4762 & 0,599 \\
\hline & Caatinga Aberta & 2252,97 & 24,3737 & 431 & 4,6628 & 4,6531 \\
\hline & Caatinga Densa & 3836,43 & 41,5043 & 394 & 4,2625 & 12,5895 \\
\hline \multirow{6}{*}{$\begin{array}{c}\text { Unidade } \\
\text { Lameiro - Serra } \\
\text { do Ramalho- } \\
2006\end{array}$} & Agricultura & 856,08 & 9,2615 & 255 & 2,7587 & 3,4137 \\
\hline & Pastagem & 1933,29 & 20,9152 & 159 & 1,7201 & 6,5128 \\
\hline & Solo Exposto & 187,38 & 2,0272 & 36 & 0,3895 & 0,2035 \\
\hline & Água & 177,3 & 1,9181 & 33 & 0,357 & 0,4644 \\
\hline & Caatinga Aberta & 2608,29 & 28,2177 & 381 & 4,1218 & 5,655 \\
\hline & Pastagem & 2689,11 & 29,0921 & 81 & 0,8763 & 9,7395 \\
\hline \multirow{6}{*}{$\begin{array}{c}\text { Unidade } \\
\text { Lameiro - Serra } \\
\text { do Ramalho- } \\
2021\end{array}$} & Caatinga Densa & 2482,11 & 26,8526 & 66 & 0,714 & 10,4289 \\
\hline & Solo Exposto & 207,54 & 2,2453 & 34 & 0,3678 & 0,2093 \\
\hline & Água & 210,15 & 2,2735 & 31 & 0,3354 & 0,5063 \\
\hline & Agricultura & 1046,25 & 11,3188 & 21 & 0,2272 & 8,0999 \\
\hline & Água & 98,1 & 1,0358 & 26 & 0,2745 & 0,3687 \\
\hline & Solo exposto & 451,08 & 4,7629 & 24 & 0,2534 & 1,0985 \\
\hline
\end{tabular}


Quadro - Métricas da paisagem das áreas de estudo, comunidades quilombolas e assentamento Serra do Ramalho - Unidade de paisagem Tabuleiro

\section{9 - Considerações Finais}

A importância desses estudos no conhecimento da cobertura vegetal é destacada por autores como Lang e Blaschke (2009), por sua aplicação no planejamento ambiental e em estudos da paisagem. Entre os métodos de mapeamento do uso e cobertura da Terra e da cobertura vegetal, se destaca o Sensoriamento Remoto baseado em sensores orbitais. Strand et al. (2007) ressaltam importância da ferramenta na avaliação de ecossistemas florestais em múltiplas escalas espaciais e temporais e no monitoramento da composição da floresta, estrutura e função. Crosta (1993) destaca que a viabilidade desta técnica para este tipo de aplicação é devido ao seu caráter multiescalar, à rapidez, eficiência e à periodicidade, que atribuem maior precisão no entendimento da dinâmica do uso.

A presente pesquisa constatou que a região de Médio São Francisco nas proximidades de Bom Jesus da Lapa apresentou grandes mudanças no âmbito da distribuição dos usos e cobertura do solo na planície de inundação e seu entorno imediato. A análise do cenário de 1972 foi bastante prejudicado devido aos fatores limitantes das cenas do Landsat-1, no entanto qualitativamente é possível afirmar um predomínio na região de área de caatinga densa, com grandes fragmentos de caatinga densa, os indícios de atividades antrópicas ficavam restritas à alguns pontos de ocupação ao longa da área de estudos.

Nos períodos de entre 1988 e 2006, já com a utilização métricas da paisagem, devido ao avanço dos satélites Landsat, foi possível observar a distinção entre os processos da ocupação das margens do Rio São Francisco, os dois lados do curso fluvial apresentaram trajetórias essencialmente diferentes. De forma que na margem oeste foi possível notar a intensa evolução dos loteamentos do Projeto Especial de Colonização Serra do Ramalho, sendo a área que concentrou os principais focos de fragmentação e desmatamento do buffer nessas áreas de caatinga densa. 
O cenário de 2006 apresentou o ponto mais baixo da trajetória da evolução da distribuição de cobertura vegetal na área de estudos. Neste ano foram alcançados os menores índices em todas as áreas, no entanto as comunidades quilombolas apresentaram nível de conservação de áreas de vegetação caatinga maiores do que os outros recortes, sendo onde, percentualmente, havia maior disponibilidade de caatinga densa. Um panorama diferente foi observado em 2021, com um movimento de recuperação das matas de caatinga.

No ponto de análise de correlação entre os eventos e a modificação da paisagem, pudesse observar que a implementação do assentamento de Serra do Ramalho em 1973 foi principal a ato político-administrativo do ponto de vista de impactos à cobertura vegetal. Os territórios da comunidades quilombolas apresentaram um comportamento mais estável, sem uma ligação explicita a um ato administrativo de uma titulação formal.

O modelo de agrovilas implementados em Serra do Ramalho apresentou no contexto da análise de cobertura vegetal extremamente danoso aos ecossistemas de caatinga, apresentando os maiores índices de desflorestamento e as menores taxas de recuperação de áreas vegetadas em todos períodos e unidades paisagens estudados. Tal comportamento, além dos percalços dados pelo processo de realocamento de grandes populações, talvez pode ser explicado pela imposição dos modelos de agrovilas imposto como forma de produção às comunidades com hábitos ambientais. (ESTRELA, 2000; NASCIMENTO e SILVA, 2011)

As análises de distribuição de cobertura vegetal e de detecção de mudanças apontaram que as comunidades quilombolas tem ao longo do tempo modificando a paisagem de modo gradual a partir da reprodução de hábitos culturais-ambientais vazanteiros que acarretam numa maior conservação maior das áreas vegetadas, especialmente as de caatinga densa. Outro ponto no qual os dados indicaram tal preservação foram nas análises de detecção de mudanças que apontaram que nos territórios quilombolas tiveram no período perdas global, as comunidades os menores índices de desmatamentos, e o inverso nos períodos de resiliência. De certo modo, uma assinatura desses grupos aos seus relativos territórios e demonstrando a legitimidade de seus territórios sob a forma da paisagem. 


\section{0 - Referências Bibliográficas}

ADAMS, Cristina; CHAMLIAN MUNARI, Lucia; VAN VLIET, Nathalie; SERENI MURRIETA, Rui Sergio; PIPERATA, Barbara Ann; FUTEMMA, Celia; NOVAES PEDROSO, Nelson; SANTOS TAQUEDA, Carolina; ABRAHÃO CREVELARO, Mirella; SPRESSOLA-PRADO, Vânia Luísa. Diversifying Incomes and Losing Landscape Complexity in Quilombola Shifting Cultivation Communities of the Atlantic Rainforest (Brazil). Human Ecology, vol. 41, no. 1, p. 119-137, 2013. https://doi.org/10.1007/s10745-012-9529-9.

ADAMS, Cristina; MURRIETA, Rui Sérgio S.; SANCHES, Rosely Alvim. Agricultura e alimentação em populações ribeirinhas das várzeas do Amazonas: novas perspectivas. Ambiente \& Sociedade, vol. 8, no. 1, p. 65-86, 2005. https://doi.org/10.1590/s1414-753x2005000100005.

ARRUDA, R. S. V. “Populações tradicionais” e a proteção dos recursos naturais em Unidades de Conservação. In: DIEGUES, A. C. (Org.). Etnoconservação: novos rumos para a proteção da natureza nos trópicos. 2. ed. São Paulo: Hucitec e NUPAUB, p. 273-290, 2000

ASPINALL, R. J; HILL. M. J.. Land use change: science, policy and management. Boca Raton: CRCRPress, 2008. 216p.

CROSTA, A.P.. Processamento digital de imagens de sensoriamento remoto. Campinas: Editora da Unicamp, 1993. 170p.

DUPRAT, Deborah; PEREIRA, D E Britto. As populações remanescentes de quilombos - direitos do passado ou garantia para o futuro? Série Cadernos do CEJ, vol. 24, p. 272, 2003.

ESTRELA, E. S. Descompassos e dissonâncias em torno das Agrovilas de Serra do Ramalho-Ba , 2000

FERNANDES, Nelson Ferreira. Modelagem em Geografia Física: Teoria, Potencialidades e Desafios Modeling in Physical Geography: Theory, Potentialities and Challenges. Espaço Aberto, vol. 6, no. 1, p. 
209-247,

2016.

Available

at:

https://dialnet.unirioja.es/servlet/articulo?codigo=5793398.

GIFFONI PINTO, Raquel; DE MORAES WANDERLEY, Luiz Jardim. Memória e Resistência: a experiência do mapeamento participativo da comunidade Quilombola de Linharinho, Espírito Santo. [S. I.: s. n.], 2010. Disponível

em: http://beu.extension.unicen.edu.ar/xmlui/bitstream/handle/123456789/347/ ACSELRAD \%28coord\%29_2010_cartografia social e dinâmicas territoriais.pdf? sequence $=1$ \&isAllowed $=y$.

GONÇALVES, C. W. P.. A Globalização da Natureza e a Natureza da Globalização . Rio de Janeiro: Civilização Brasileira, 2006

GUERRA, A.J.T.; CUNHA, S.B. da. Geomorfologia: uma atualização de bases e conceitos. Rio de Janeiro: Bertrand Brasil, 1994.

HAESBAERT, R 0 território em tempos de globalização. ETC, espaço, tempo e crítica Revista Eletrônica de Ciências Sociais Aplicadas e outras coisas ISSN 1981-3732 http://www.uff.br/etc15 de Agosto de 2007, $n^{\circ} 2$ (4), vol.

HELENA P. T. MACHADO, Maria; DOS S. GOMES, Flávio; B. A. ARIZA, Marília; HELENA P. T. MACHADO, Maria; DOS S. GOMES, Flávio; B. A. ARIZA, Marília. Quilombos. Atlantic History, , p. 1-33, 2019. https://doi.org/10.1093/obo/9780199730414-0314.

INSTITUTO BRASILEIRO DE GEOGRAFIA E ESTATÍSTICA. Manual técnico de uso da Terra. 2.ed. Rio de Janeiro, 2006.

INSTITUTO NACIONAL DE COLONIZAÇÃO E REFORMA AGRÁRIA. Relatório Técnico de Identificação e Delimitação - RTID Processo: $54160.001788 / 2005-81,2009$

LANG, S.; BLASCHKE, T. Análise da Paisagem com SIG. São Paulo: Oficina de Textos, 2009. 424 p. Tradução Hermann Kux.

LAUER, Donald T.; MORAIN, Stanley A.; SALOMONSON, Vincent V. The landsat program: Its origins, evolution, and impacts. 
Photogrammetric Engineering and Remote Sensing, vol. 63, no. 7, p. 831-838, 1997. .

MOTA, Fernanda; GONÇALVES, Matheus; AGUIAR, Marilton; ADAMATTI, Diana. Google Earth Engine e sua aplicabilidade na gestão de recursos hídricos. , p. 161-170, 2021. https://doi.org/10.5753/wcama.2021.11030.

DO NASCIMENTO, Maria Anezilany Gomes; DA SILVA, Cicero Nilton Moreira. Entre a Memória $E$ a Reterritorialização: Impactos Socioespaciais Da Construção De Barragens. Xiv Encontro Nacional Da Anpur, 2011. .

OLIVEIRA, Cláudia Luz de. Vazanteiros do rio São Francisco: estudo sobre populações tradicionais e territorialidade no Norte de Minas Gerais. , p. 135, 2005. .

ROCHA P.C. Sistemas rio-planície de inundação: geomorfologia e conectividade hidrodinâmica. Caderno Prudentino de Geografia, Presidente Prudente, n.33, v.1, p.50-67, jan./jul.2011.

SANTOS, M.; SILVEIRA, M. L.. O Brasil: território e sociedade no início do século XXI. 4. ed. Rio de Janeiro: Record, 2002.

SANTOS, Regnaldo Gouveia. Impactos sócio-ambientais à margem do rio São Francisco: um estudo de caso. 2008.

SAUER, Carl Ortwin. A morfologia da paisagem. University of Californial Publications in Geography, vol. 2, no. 2, p. 19-54, 1925.

SOUZA, Angela Fagna Gomes de; BRANDÃO, Carlos Rodrigues. PAISAGEM, IDENTIDADE E CULTURA SANFRANCISCANA: sujeitos e lugares das comunidades tradicionais localizadas no entorno e nas ilhas do médio rio São Francisco. Geo UERJ, vol. 1, no. 23, p. 77-98, 2012. https://doi.org/10.12957/geouerj.2012.3698.

TIAN, Shaohong; ZHANG, Xianfeng; TIAN, Jie; SUN, Quan. Random forest classification of wetland landcovers from multi-sensor data in 
the arid region of Xinjiang, China. Remote Sensing, vol. 8, no. 11, p. 114, 2016. https://doi.org/10.3390/rs8110954.

TURNER, M. G. Landscape ecology: the effect of pattern on process. Annual review of ecology and systematics. Vol. 20, , p. 171197, 1989. https://doi.org/10.1146/annurev.es.20.110189.001131.

VARGAS I.A. Território, Identidade, Paisagem e Governança No Pantanal Matogrossense: Um Caleidoscópio Da Sustentabilidade Complexa In: LEFF, E., ARGUETA, A., BOEGE, E. Y GONÇALVES, C. W. $P$. Más allá del desarrollo sostenible: la construción de una racionalidad ambiental para la sustentabilidad: una visión desde la América Latina. In: LEFF, E. (Coord.). La transición hacia el desarrollo sustentable. Perspectivas de América Latina y el Caribe. México, PNUMA, 2002. (p. 479577

ZONNEVELD, Isaak S. The land unit - A fundamental concept in landscape ecology, and its applications. Landscape Ecology, vol. 3, no. 2, p. 67-86, 1989. https://doi.org/10.1007/BF00131171. 